DOI $10.23859 / 2587-8344-2019-3-1-4$

УДК 94(47).084

Старостин Сергей Игоревич

Ведущий архивист,

Вологодский областной архив новейшей политической истории

(Вологда, Россия)

vol_star@mail.ru

Starostin Sergei

Lead archivist,

Vologda Regional Archive of Modern Political History

(Vologda, Russia)

vol_star@mail.ru

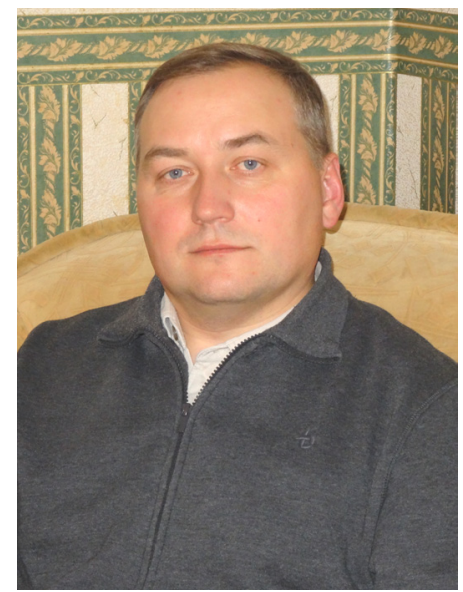

Массовые депортации и система спецпоселений в Вологодской области в 1930-1950-е годы*

\title{
Mass Deportations and the System of Special Settlements in Vologda Region in the 1930s-1950s
}

Аннотация. В статье рассматривается история массовых депортаций населения, а также формирования и эволюции системы спецпоселений в 1930-1950-е годы на территории Вологодской области. Определяющую роль в возникновении и функционировании данной системы играли органы ОГПУ-НКВД-МВД-МГБ СССР. В период коллективизации сельского хозяйства с территории Вологодской области производилось выселение репрессированных крестьян, в то же время она стала местом ссылки тысяч советских и иностранных граждан. С принятием Закона Российской Федерации от 18 октября 1991 года № 1761-1 «О реабилитации жертв политических репрессий» насильственное выселение в административном порядке на спецпоселение было признано политической репрессией. Органами внутренних дел Вологодской области за 1992-2017 гг. рассмотрено 24877 заявлений граждан о реабилита-

* Для цитирования: Старостин С.И. Массовые депортации и система спецпоселений в Вологодской области в 1930-1950-е годы // Historia Provinciae - Журнал региональной истории. 2019. Т. 3. № 1. С. 212-317. DOI: 10.23859/2587-8344-2019-3-1-4

For citation: Starostin, S. "Mass Deportations and the System of Special Settlements in Vologda Region in the 1930s-1950s", Historia Provinciae - The Journal of Regional History, vol. 3, no. 1 (2019): 212-317, http:// doi.org/10.23859/2587-8344-2019-3-1-4

(С) Старостин С.И., 2019

(C) Starostin S., 2019 
ции, по результатам проверки которых было выдано 10899 справок о реабилитации граждан из числа репрессированных в административном порядке, а также членов их семей.

Ключевые слова: Вологодская область, ОГПУ, НКВД СССР, массовые депортации, спецпоселенцы, политические репрессии, реабилитация.

Abstract. The article considers the history of mass deportations of population as well as formation and development of the system of special settlements in the territory of Vologda Region in 1930s-1950s. The defining role in establishing and operating the system was played by the bodies of OGPU-NKVD-MVD-MGB of the USSR. During the period of collectivization of agriculture peasants subjected to repression were removed from the territory of Vologda Region, which at the same time became the place of exile for thousands of Soviet and foreign citizens. With the adoption of the Law of the Russian Federation No. 1761-1 of October 18, 1991 "On the rehabilitation of victims of political repression" forced administrative removal to special settlements was recognized as political repression. From 1992 till 2017 the bodies of internal affairs of Vologda Region considered 24877 applications for rehabilitation; the verification of the applications resulted in issuing 10899 certificates of rehabilitation for the citizens who had undergone repression by administrative order and for the members of their families.

Keywords: Vologda Region, OGPU, USSR NKVD, mass deportations, special settlers, political repression, rehabilitation

Благодарность. Статья подготовлена при финансовой поддержке Российского фонда фундаментальных исследований, проект № 18-09-00554 «Органы внутренних дел в контексте взаимоотношений власти и общества России в XX веке (на материалах Европейского Севеpa)».

Gratitude. This paper was prepared with the financial support of the Russian Foundation for Basic Research, project No. 18-09-00554 "Internal affairs agencies in the context of relationships between the authorities and the society in Russia in the $20^{\text {th }}$ century (based on the materials of Northern European Russia)"

\section{Введение}

Массовые депортации различных групп населения в отдаленные районы СССР, проводимые в 1930-1950-е гг. в СССР, являлись составной частью репрессивной политики государства.

История спецпоселений (спецпоселенцев) насчитывает более трех десятилетий, из которых 14 лет спецпоселения являлись структурной частью ГУЛАГа ОГПУ-НКВД СССР. В течение 1931-1959 гг. последние находились в ведении одного и того же отдела, название и ведомственная принадлежность которого периодически менялись: 1931-1934 гг. - Отдел по спецпереселенцам ГУЛАГа ОГПУ СССР; 1934-1940 гг. - Отдел трудовых поселений ГУЛАГа НКВД СССР; 1940-1941 гг. - Управление трудовых поселений ГУЛАГа НКВД СССР; 1940-1941 гг. - Управление исправительно-трудовых колоний и трудовых по- 
селений ГУЛАГа НКВД СССР; 1941-1944 гг. - Отдел трудовых и специальных поселений ГУЛАГа НКВД СССР; 1944-1950 гг. - Отдел спецпоселений НКВДМВД СССР; 1950-1953 гг. - 9-е Управление МГБ СССР; 1953-1954 гг. - Отдел «П» МВД СССР; 1954-1959 гг. - 4-й спецотдел МВД СССР (ликвидирован в 1959 году, находившиеся на спецпоселении лица перешли в ведение Главного Управления милиции МВД СССР) ${ }^{1}$.

Отличительными признаками данного вида репрессий являлись их внесудебный (административный) характер и списочность (контингентность). Они были направлены не на конкретное лицо, не на индивидуального гражданина, а на целую группу лиц, подчас весьма многочисленную, отвечающую заданным сверху критериям; решение принималось, как правило, руководством партии и правительства, по инициативе силовых и других ведомств.

Для направления на спецпоселение были необходимы определенные критерии (признаки). Они были различны для разных категорий спецпоселенцев и в разные периоды депортаций. Основными являлись: 1) классовый признак (раскулаченные крестьяне, бывшие дворяне, казаки); 2) конфессиональный признак (духовенство, истинно православные христиане, иеговисты и др.); 3 ) политический признак (члены запрещенных партий, члены семей изменников родины, члены семей ОУН-УПА, власовцы); 4) этнический признак («наказанные народы» - немцы, карачаевцы, калмыки, ингуши, чеченцы, балкарцы, крымские татары и др.).

Юридический статус спецпоселенцев определялся карательными ведомствами, в основном исходя из формального признака - на основании каких документов та или иная категория граждан попала на спецпоселение. Официальная статистика ОГПУ-НКВД-МВД-МГБ применяла к репрессированным группам населения различные термины: спецпереселенцы, трудпоселенцы, выселенцы, ссыльнопоселенцы и др. Однако, основными и неизменными оставались «специфические» правила (особенности): 1) принудительное проживание вместе с семьями в определенной местности, как правило, в новой, непривычной и рискованной для выживания среде обитания; 2) принудительное исполнение всех правил, связанных с пребыванием в данном статусе; 3) принудительный труд; 4) отсутствие определенных сроков наказания.

В постсоветский период вышло значительное количество научных работ и сборников документов по истории спецпоселений. Российские и зарубежные авторы и составители раскрыли в них как историю разработки и осуществления антикрестьянской репрессивной политики в ходе принудительной коллективизации в СССР в форме высылки и пребывания на спецпоселении (трудпоселе-

${ }^{1}$ Государственный архив Российской Федерации (ГАРФ). Ф. 9479. Историческая справка. 
нии) сотен тысяч крестьянских семей, так и этнические депортационные кампании и операции, проводившиеся в 30-50-е годы XX века ${ }^{2}$.

${ }^{2}$ Адибеков Г.М. Спецпереселенцы - жертвы «сплошной коллективизации». Из документов «особой папки» политбюро ЦК ВКП(б). 1930-1932 гг. // Исторический архив. 1994. № 4. С. 145-180; Белковец Л.П. Административно-правовое положение российских немцев на спецпоселении. 1941-1955 гг. М.: РОССПЭН, 2008; Бердинских В.А. Спецпоселенцы. Политическая ссылка народов Советской России. Киров: Кировская областная типография, 2003; Бердинских В.А., Бердинских И.В., Веремьев В.И. Система спецпоселений в Советском Союзе 1930-1950-х годов. М.: РОССПЭН, 2017; Бугай Н.Ф. Иосиф Сталин - Лаврентию Берии: «Их надо депортировать...»: документы, факты, комментарии. М.: Дружба народов, 1992; Бугай Н.Ф. Л. Берия - И. Сталину: «Согласно Вашему указанию...». [о депортации народов СССР в 30-е - 40-е гг.] М.: АИРО-ХХ, 1995; Бугай Н.Ф. «Мобилизовать немцев в рабочие колонны... И. Сталин»: сборник документов (1940-е годы). М.: Готика, 1998; Бугай Н.Ф. Депортация народов Крыма: документы, факты, комментарии. М.: ИНСАН, 2002; Бугай Н.Ф., Гонов А.М. Кавказ: народы в эшелонах (20-60-е годы). М.: ИНСАН, 1998; Вашкау Н.Э. Российские немцы в «трудовой армии»: вклад в Победу // Воинский подвиг защитников Отечества: традиции, преемственность, новации. Материалы межрегиональной научнопрактической конференции. Ч. 3. Вологда: Вологодский институт развития образования, 2000. С. 200-207; Вашкау Н.Э. Женщина в трудармии // Проблемы истории Второй мировой войны. Сборник научных работ. Вологда: Вологодский государственный университет, 2000. С. 82-98; Виола Л. Крестьянский ГУЛАГ: мир сталинских спецпоселений. М.: РОССПЭН, 2010; Гинцбберг Л.И. По страницам «особых папок» политбюро ЦК ВКП(б) // Вопросы истории. 1996. № 8. С. 16-30; Гинцбберг Л.И. Массовые депортации крестьян в 1930-1931 годах и условия их существования в Северных краях (по материалам «особых папок» политбюро ЦК ВКП(б) и «комиссии Андреева»// Отечественная история. 1998. № 2. С. 190-196; Гурьянов A.Э. Польские спецпереселенцы в СССР в 1940-1941 гг. // Репрессии против поляков и польских граждан. М.: Звенья, 1997. С. 114-136; Земсков В.Н. Спецпоселенцы в СССР, 19301960. М.: Наука, 2005; Земсков В.Н. «Кулацкая ссылка» в 1930-е годы: численность, расселение, состав // Население России в ХХ веке / под ред. Ю.А. Полякова. Т. 1. М.: РОССПЭН, 2000. С. 277-310; Земсков В.Н. Депортация населения. Спецпоселенцы и ссыльные. Заключенные. // Население России в ХХ веке / под ред. Ю.А. Полякова. Т. 2. М.: РОССПЭН, 2001. С. 166-196; Земсков В.Н. Судьба «кулацкой ссылки» в 1940-1954 гг. // Население России в ХХ веке / под ред. Ю.А. Полякова. Т. 2. М.: РОССПЭН, 2001. С. 291-311; Ивниикий Н.А. Коллективизация и раскулачивание: начало 30-х гг. М.: Интерпракс, 1994; Ивницкий Н.А. Репрессивная политика советской власти в деревне. 1928-1933. М.: Институт российской истории РАН, 2000; Ивницкий Н.А. Судьба раскулаченных в СССР. М.: Собрание, 2004; Красильников С.А. Серп и молох. Крестьянская ссылка в Западной Сибири в 1930-е годы. М.: РОССПЭН, 2003; Красильников С.А., Саламатова М.С., Ушакова С.Н. Корни и щепки. Крестьянская семья на спецпоселении в Западной Сибири в 1930-х - начале 1950-х гг. М.: РОССПЭН, 2010; Полян П.М. Не по своей воле...: История и география принудительных миграций в СССР. М.: ОГИ-Мемориал, 2001; Суслов А.Б. Спецконтингент в Пермской области (1929-1953 гг.). М.: РОССПЭН, 2010; Чебыкина Т. Депортация немецкого населения из европейской части СССР в Западную Сибирь (1941-1945 гг.) // Репрессии против советских немцев. Наказанный народ. М.: Звенья, 1999. С. 118-127; Шевяков А.А. «Тайны» послевоенной репатриации // Социологические исследования. 1993. № 8. С. 3-12; Шевяков А.А. Репатриация советского мирного населения и военнопленных, оказавшихся в оккупационных зо- 
В исторической литературе нашего региона (Республики Карелия и Коми, Архангельская, Вологодская и Мурманская области) происходило быстрое освоение проблематики как истории политических репрессий в целом, так и нахождения депортированных граждан СССР и других стран в условиях ограничения прав и свобод. Именно в указанном регионе появились первые сборники архивных документов, отражающих процессы «раскулачивания» и функционирования ГУЛАГа, использования принудительного труда спецпоселенцев в региональном масштабе ${ }^{3}$.

Исследования по изучению истории спецпоселения и сборники документов на региональном уровне отличаются широким спектром рассмотренных проблем. Особенно следует отметить работы Л.И. Вавулинской, А.Э. Гурьянова, Г.Ф. Доброноженко, Н.М. Игнатовой, О.А. Никитиной, М.Б. Рогачева, Л.С. Шабаловой, В.Я. Шашкова ${ }^{4}$, которые раскрывают причины и этапы депор-

нах государств антигитлеровской коалиции // Население России в 1920-1950-е годы: численность, потери, миграции. М.: Институт российской истории РАН, 1994. С. 195-222; Шевяков А.А. Гитлеровский геноцид и репатриация советского населения // Людские потери в СССР в период Второй мировой войны. СПб.: Русско-Балтийский информационный центр «Блиц», 1995. С. 178-181; История сталинского ГУЛАГа. Конец 1920-х - первая половина 1950-х годов. Т. 5: Спецпереселенцы в СССР / отв. ред. и сост. Т.В. Царевская. М.: РОССПЭН, 2004; Политбюро и крестьянство: высылка, спецпоселение. 1930-1940. Кн. 1 / отв. ред. Н.Н. Покровский. М.: РОССПЭН, 2005; Политбюро и крестьянство: высылка, спецпоселение. 1930-1940. Кн. 2 / отв. ред. Н.Н. Покровский, В.П. Данилов, С.А. Красильников, Л. Виола. М.: РОССПЭН, 2006; Сталинские депортации. 1928-1953 / под общ. ред. акад. А.Н. Яковлева; сост. Н.Л. Поболь, П.М. Полян. М.: МФД: Материк, 2005; Dahlmann D. “Operation erfolgreich durchgeführt": Die Deportationen der Wolgadeutschen 1941 // Flucht und Vertreibung: zwischen Aufrechnung und Verdraengung. Wien: Picus Verlag, 1994; Eisfeld A., Herdt V. Deportation, Sondersiedlung, Arbeitsarmee: Deutsche in der Sowjetunion 1941 bis 1956. Köln: Wissenschaft und Politik, 1996; Merl S. Das System der Zwangsarbeit und die Opferzahl im Stalinismus // Geschichte im Wissenschaft und Unterricht. 1995. Jg. 46. Heft 5/6. S. 277-301; Pohl J.O. The Stalinist Penal System: A Statistical History of Soviet Repression and Terror. 19301953. Jefferson, NC; London: McFarland, 1997; Martin T. The Origin of Soviet Ethnic Cleansing // The Journal of Modern History. 1998. Vol. 70. № 4. P. 812-861.

${ }^{3}$ Из истории раскулачивания в Карелии, 1930-1931 гг.: документы и материалы / сост. Л.И. Драздович и др. Петрозаводск: Карелия, 1991; ГУЛАГ в Карелии: сборник документов и материалов (1930-1941) / сост. А.Ю. Жуков и др. Петрозаводск: Карельский научный центр РАН, 1992; Лесная промышленность Коми АССР: сборник документов, 1917-1960. Сыктывкар: Коми книжное издательство, 1989.

${ }^{4}$ Вавулинская Л.И. Спецпереселенцы и иностранные военнопленные в Карелии в середине 1940-х - середине 1950-х гг. Петрозаводск: Карельский научный центр РАН, 2013; Гурьянов А.Э. Введение // Польские спецпереселенцы в Архангельской области. Ч. 1. Индекс репрессированных. Вып. XIV. Варшава: Центр Карта; Информационный центр Архангельской области; Мемориал, 2003. С. 754-810; Доброноженко Г.Ф. Проведение сплошной коллективизации в Северном крае (1929-1932 гг.): дис. ... канд. ист. наук. Петрозаводск, 1993; Доброноженко Г.Ф. Коллективизация на Севере. 1929-1932 гг. Сыктывкар: Сыктывкарский 
таций на Европейский Север, прием и расселение спецпоселенцев, их хозяйственное положение, социально-бытовое устройство, трудовое использование, деятельность органов ОГПУ-НКВД-МВД-МГБ по установлению и обеспечению режима спецпоселения на территории современных республик Карелия и Коми, Архангельской и Мурманской областей.

университет, 1994; Доброноженко Г.Ф., Шабалова Л.С. Кулацкая ссылка в Коми области в первой половине 1930-х годов // Покаяние: мартиролог. Т. 4. Ч. 1. Сыктывкар: Коми книжное издательство, 2001. С. 15-123; Игнатова Н.М. Спецпереселенцы в Республике Коми в 19301940-е гг.: заселение и условия жизни // Корни травы: сборник статей молодых историков. М.: Звенья, 1996. С. 23-35; Игнатова Н.М. Периодизация процесса спецпереселения в Республике Коми // Актуальные проблемы краеведения Республики Коми. Сыктывкар: Общество изучения Коми края; Министерство по делам национальностей Республики Коми, 1997. С. 32-33; Игнатова Н.M. Социальный протест спецпереселенцев в Северном крае в 19301936 гг. // Двинская земля: материалы межрегиональных общественно-научных историкокраеведческих Стефановских чтений. Котлас: Правда Севера, 2002. С. 81-89; Игнатова Н.M. Социальный протест спецпереселенцев в Архангельской области и Республике Коми в 19411945 гг. // Защитники Отечества: материалы XV региональных общественно-научных чтений по военно-исторической тематике. Архангельск: Правда Севера, 2004. С. 148-156; Игнатова H.M. Спецпереселенцы в Республике Коми в 1930-1950-е годы. Сыктывкар: Коми научный центр Института языка, литературы и истории, 2009; Игнатова Н.М. Смертность спецпереселенцев в Северном крае в 1930-е гг.: причины, масштаб, статистический учет // Новый исторический вестник. 2011. № 2 (28). С. 42-52; Игнатова Н.M. Принудительный труд спецпереселенцев как системный фактор индустриального освоения северных регионов в 19301950 гг. // История сталинизма: Принудительный труд в СССР. Экономика, политика, память: материалы международной научной конференции. Москва, 28-29 октября 2011 г. / отв. ред.: Л.И. Бородкин, С.А. Красильников, О.В. Хлевнюк. М.: РОССПЭН, 2013. С. 433-449; Игнатова Н.М. Призыв трудпереселенцев в СССР на фронт в 1942 г. // Вопросы истории. 2013. № 11. С. 97-103; Никитина О.А. Коллективизация и раскулачивание в Карелии: автореф. дис. ... канд. ист. наук. Институт Российской истории РАН, 1993; Рогачев М.Б. Депортация польских граждан в Коми АССР (1940-1941 гг.) // Поляки в России: история ссылки и депортации. СПб., 1995. С. 31-46; Рогачев М.Б. Страницы польской трагедии: факты и документы // Покаяние. Мартиролог. Т. 5. Сыктывкар: Коми книжное издательство, 2002. С. 14 463; Упадышев Н.В. ГУЛАГ на Европейском Севере: генезис, эволюция, распад. Архангельск: Поморский университет, 2007; Шашков В.Я. Спецпереселенцы на Мурмане. Роль спецпереселенцев в развитии производительных сил на Кольском полуострове (19301936 гг.). Мурманск: Мурманский государственный педагогический университет, 1993; Шашков В.Я. Раскулачивание в СССР и судьбы спецпереселенцев (1930-1954 гг.): дис. ... докт. ист. наук. Московский государственный университет им. М.В. Ломоносова, 1995; Шашков В.Я. Репрессии в СССР против крестьян и судьбы спецпереселенцев КарелоМурманского края. Мурманск: Мурманский государственный педагогический университет, 2000; Шашков В.Я., Козлов С.С., Лобченко Л.Н. ГУЛАГовская система спецпереселений Северного края для «бывших кулаков». Мурманск: Мурманский государственный педагогический университет, 2008 и др. 
К истории нахождения депортированных граждан СССР на территории Вологодской области впервые обратились В.Б. Конасов и В.В. Судаков ${ }^{5}$, которые в своих работах отразили положение спецпоселенцев в Вологодской области в годы Великой Отечественной войны. Однако, на наш взгляд, данная тема все еще находится на периферии исследований и нашла свое отражение лишь в отдельных публикациях ${ }^{6}$. При этом наиболее полное освещение получила история нахождения в Вологодской области польских спецпереселенцев ${ }^{7}$.

${ }^{5}$ Конасов В.Б., Судаков В.В. Эхо минувшей войны: из истории Вологодской области. Вологда: Институт повышения квалификации и профессиональной переподготовки кадров, 1994. C. 57-66.

${ }^{6}$ Старостин С.И. Трагические страницы истории. Точка еще не поставлена... // Историческое краеведение и архивы: материалы V и VI научно-практических конференций. Вып. 5. Вологда: Полиграфист, 1999. С. 67-76; Старостин С.И. История советской ссылки на Европейском Севере: 1930-1956 гг. (на материалах архивов Вологодской области) // История и перспективы уголовно-исполнительной системы России: сборник материалов научнопрактического семинара (Вологда, 4 апреля 2002 года). Вологда: Вологодский институт права и экономики Минюста России, 2002. С. 98-106; Старостин С.И. Структура и функции администрации спецпереселенческих поселков Вологодской области в 1930-1956 годы // Историческое краеведение и архивы: сборник статей. Вып. 9. Вологда: Полиграфист, 2003. С. 109-125; Старостин С.И. Документы архива УВД Вологодской области о судьбах депортированных граждан СССР и других стран // Историческое краеведение и архивы: материалы межрегиональной научной конференции. 20 марта 2003 г. Вып. 10. Вологда: Полиграфист, 2004. С. 184-196; Старостин С.И. Депортированные советские и иностранные граждане в годы Великой Отечественной войны (на материалах Архангельской и Вологодской областей) // 1941-1945: уроки войны - уроки правды, мужества и патриотизма: материалы межрегиональной научно-практической конференции. Вологда, 24-25 февраля 2005 г. Вологда: Русь, 2006. С. 101-112; Старостин С.И. Переселение поляков из Вологодской области (1944 год) // Историческое краеведение и архивы: материалы областной научно-практической конференции. Вып. 17. Вологда: Полиграфист, 2010. С. 138-145; Кузьминых А.Л., Старостин С.И. Польские военнопленные и спецпереселенцы в Вологодской области (1939-1941 гг.) // Россия - Польша: филологический и историко-культурный дискурс: сборник статей участников Международной научной конференции (Магнитогорск, 18-19 ноября 2005 г.). Магнитогорск: Магнитогорский государственный университет, 2005. С. 104-111; Польские спецпереселенцы в Вологодской области. Алфавитные списки 14226 польских граждан, высланных в 1940 г. из западных областей БССР и УССР. Вып. XVII / сост. А. Дзенкевич, Э. Рыбарска, А. Гурьянов, А. Рачинский и С. Старостин. Варшава: Центр Карта; Информационный центр Архангельской области; Мемориал, 2005; Артемова O.B. Спецпереселенцы в Вожегодском районе (1930-е годы) // Вожега: краеведческий альманах. Вологда: Русь, 1995. С. 195-220; Цветков С.Н. О настроениях граждан СССР немецкой национальности, вернувшихся из-за границы на жительство в Вологодскую область после Великой Отечественной войны // Воинский подвиг защитников Отечества: традиции, преемственность, новации: материалы межрегиональной научно-практической конференции. Ч. 3. Вологда: Вологодский институт развития образования, 2000. С. 200-207.

7 Кузьминых А.Л., Старостин С.И. Поляки в Вологодской области: репрессии, плен, спецпоселение (1937-1953 гг.). Вологда: Древности Севера, 2014. 
В данной статье на документах государственных и ведомственных архивов Вологодской и Архангельской областей будет рассмотрена проблема проведения массовых насильственных депортаций населения с территории современной Вологодской области и нахождения на ее территории различных контингентов спецпоселенцев в 1930-1956 годы, вопросы численности и географии размещения репрессированных граждан.

\section{Основная часть}

По данным Н.А. Ивницкого, в ходе коллективизации в СССР было раскулачено (административно-репрессивными и экономическими мерами) не менее одного миллиона крестьянских хозяйств с населением в 5-6 млн. человек, только незначительная часть которых принадлежала к эксплуататорскому слою деревни. Более трети раскулаченных или 2 млн 140 тыс. человек было депортировано (насильственно выслано с постоянного места жительства в отдаленные районы СССР) в 1930-1933 гг. ${ }^{8}$

Трагедия массовой коллективизации не обошла стороной и Вологодскую область, часть территории которой в рассматриваемый период входила в состав Северного края (центр - г. Архангельск), часть - в состав Ленинградской области.

Практическое осуществление политики «ликвидации кулачества как класса» началось в середине зимы 1930 г., после принятия постановления ЦК ВКП(б) от 30 января 1930 г. «О мероприятиях по ликвидации кулацких хозяйств в районах сплошной коллективизации» ${ }^{9}$, постановления ЦИК и СНК СССР от 1 февраля 1930 г. «О мероприятиях по укреплению социалистического переустройства сельского хозяйства в районах сплошной коллективизации и по борьбе с кулачеством» ${ }^{10}$ и выхода приказа ОГПУ СССР № 44/21 от 2 февраля 1930 г. ${ }^{11}$, который определял механизм применения репрессивных мер к раскулачиваемым. В приказе подчеркивалось, что для осуществления поставленной партией перед органами ОГПУ задачи требуется «исключительное напряжение сил, решительность и выдержка, исключительно строгая классовая линия, четкость и быстрота действий» ${ }^{12}$.

${ }^{8}$ Ивницкий Н.А. Коллективизация и раскулачивание: начало 30-х годов. М.: Интерпракс, 1994. С. 257.

${ }^{9}$ Сборник законодательных и нормативных актов о репрессиях и реабилитации жертв политических репрессий. Ч. 1 / под ред. Г.Ф. Весновской. Курск: Курск, 1999. С. 293-299.

${ }^{10}$ Собрание законов и распоряжений Рабоче-Крестьянского Правительства СССР. М.: Управление делами Совета Народных Комиссаров Союза ССР и Совета Труда и Обороны, 1930. № 9. Ст. 105.

11 Трагедия советской деревни. 1927-1939 гг. Т. 2. Ноябрь 1929 - декабрь 1930. М.: РОССПЭН, 2000. С. 163-167.

12 Трагедия советской деревни... М., 2000. С. 163. 
Первоначально Северный крайком ВКП(б) планировал провести раскулачивание и выселение около 6000 кулацких хозяйств в районах сплошной коллективизации (по округам: Архангельскому - 1000 хозяйств, Вологодскому 2500 хозяйств, Няндомскому - 1200 хозяйств, Северо-Двинскому - 800 хозяйств, Коми области - 500 хозяйств). Оставшуюся часть кулацких хозяйств предполагалось выселить за пределы районов, на худшие земли. В остальных районах края (несплошной коллективизации) намечалось к выселению за пределы округов до 3000 кулацких хозяйств, «противодействующих мероприятиям партии и советской власти в деревне, ведущих контрреволюционную агитацию, не выполняющих государственные обязательства, вредителей и т.д.» ${ }^{13}$. При этом планировалось кулаков из Вологодского округа выселить в СевероДвинский округ, из Северо-Двинского в Архангельский округ, из Няндомского и Архангельского округов - в Коми область, а кулаков Коми области направить в ее северную часть ${ }^{14}$. Однако данный проект утвержден не был.

5 февраля 1930 г. бюро Северного крайкома ВКП(б) приняло постановление по вопросу ликвидации кулачества как класса в Северном крае ${ }^{15}$. В соответствии с ним кулачество делилось на три категории. К первой была отнесена «контрреволюционная верхушка кулачества» ${ }^{16}$ (1 500 хозяйств или $0,3 \%$ от общего числа крестьянских хозяйств), ликвидацию которой намечалось завершить во всех районах края к 20 февраля. При этом кулаки по постановлениям тройки при Полномочном представительстве ОГПУ (ПП ОГПУ) Северного края осуждались к направлению в концлагерь, а наиболее активные из них - к высшей мере наказания. Их имущество конфисковывалось, а семьи выселялись с постоянного места жительства ${ }^{17}$.

Ко второй категории относились кулацкие хозяйства в районах сплошной коллективизации. После конфискации имущества данные хозяйства подлежали выселению через ПП ОГПУ в северные необжитые районы края. Количество таких хозяйств устанавливалось окружкомами, «исходя из фактического числа кулацких хозяйств каждого района» ${ }^{18}$, но не должно было превышать 3-5 \% от общего числа хозяйств района.

Кулацкие хозяйства, не вошедшие во вторую категорию, относились к третьей категории и подлежали расселению в пределах района, на новых, отво-

${ }^{13}$ Отдел документов социально-политической истории Государственного архива Архангельской области (ОДСПИ ГААО). Ф. 290. Оп. 1. Д. 378. Л. 40.

${ }^{14}$ ОДСПИ ГААО. Ф. 290. ОП. 1. Д. 378. Л. 41.

${ }^{15}$ ОДСПИ ГААО. Ф. 290. ОП. 1. Д. 378. Л. 35-39.

${ }^{16}$ ОДСПИ ГААО. Ф. 290. ОП. 1. Д. 378. Л. 35.

${ }^{17}$ Не имеющие в своем составе трудоспособных членов переселялись на худшие земли в пределах того же района, имеющие в своем составе трудоспособных членов - в северные необжитые и неосвоенные районы края.

18 ОДСПИ ГААО. Ф. 290. ОП. 1. Д. 378. Л. 35. 
димых им за пределами колхоза, землях. Начало выселения кулаков второй и третьей категорий планировалось начать 20 марта ${ }^{19}$. Кроме того, постановление бюро Севкрайкома от 5 февраля предусматривало не только принудительное выселение, но и «добровольное» переселение в северные районы края отдельных кулацких хозяйств, с оставлением им определенного количества средств и инвентаря ${ }^{20}$.

5 февраля 1930 г. вышел приказ ПП ОГПУ по Северному краю № 131 «О мероприятиях по ликвидации кулачества как класса на территории края», в соответствии с которым по округам Северного края подлежали репрессированию 1500 человек, в том числе по Архангельскому округу - 400 чел., Няндомскому - 200 чел., Вологодскому - 400 чел., Северо-Двинскому - 300 чел., Коми области -200 чел. $^{21}$

7 февраля приказом ПП ОГПУ по Северному краю № 14/7 для непосредственного руководства операцией по раскулачиванию и выселению кулацких семей создается соответствующая оперативная группа ${ }^{22}$. Однако, 27 февраля 1930 г. постановление крайкома ВКП(б) от 5 февраля было изменено. В связи с трудностями переселения и загрузкой края переселенцами комиссия крайкома ВКП(б) количество кулацких хозяйств, подлежащих раскулачиванию по II категории, сократила до 1 \%. Остальные кулацкие хозяйства были отнесены к III категории и подлежали расселению в пределах округов ${ }^{23}$.

Само же раскулачивание и выселение проводились с грубейшими нарушениями. В Вологодском округе данные мероприятия приобрели ярко выраженный военизированный характер. Так, при проведении раскулачивания в Свердловском районе привлекались отряды вооруженных красноармейцев и комсомольцев (100 человек). В г. Кадникове было введено военное положение (выставлены пикеты, оцеплены дома). Все проходящие и проезжающие по городу и селам задерживались и подвергались аресту. Неоднократно раскулачивались жители, не занимающиеся сельским хозяйством (рабочие, учителя, пенсионеры из числа бывших служащих). При раскулачивании отбиралось все имущество (продовольствие, одежда, посуда, обувь и т.п.), которое без описи сваливалось в кладовые, а ценные вещи присваивались работниками райкома, райисполкома и милиционерами.

${ }^{19}$ ОДСПИ ГААО. Ф. 290. ОП. 1. Д. 378. Л. 37.

${ }^{20}$ ОДСПИ ГААО. Ф. 290. ОП. 1. Д. 378. Л. 37. Данное положение содержится только в решениях Северного крайкома ВКП(б).

${ }^{21}$ Поморский мемориал: Книга памяти жертв политических репрессий. Т. 1 / ред.-сост. В.Т. Белов, О.И. Корытова и В.С. Цыварев. Архангельск: Поморский государственный университет, 1999. С. 785-786.

${ }^{22}$ Поморский мемориал: Книга памяти... Архангельск, 1999. С. 788.

${ }^{23}$ ОДСПИ ГААО. Ф. 290. Оп. 1. Д. 20. Л. 33-36. 
Типичным явлением были случаи грубого насилия над крестьянами, вплоть до угрозы применения оружия. Так, в Грибцовском сельсовете бригадир по раскулачиванию и милиционер инсценировали расстрел крестьян; в Рабангском сельсовете уполномоченный райисполкома, допрашивая арестованных крестьян, стрелял в потолок и угрожал им расправой. Аналогичными методами проводилось раскулачивание и в других районах округа - Вологодском, КубеноОзерском, Харовском, Сямженском, Шуйском, Тотемском, Толшменском и др. $^{24}$

Порядок проведения раскулачивания в Ленинградской области был определен циркуляром Ленинградского облисполкома от 24 марта 1930 г. «О порядке проведения раскулачивания и о ликвидации перегибов» ${ }^{25}$. Процедура раскулачиванияя ${ }^{26}$ выглядела следующим образом: 1) бедняцкие и колхозные собрания принимали предварительное решение о раскулачивании и выселении; 2) каждый случай выселения и конфискации имущества кулацкого хозяйства рассматривался райисполкомом (утверждение решения бедноты и колхозников); 3) фактическое выселение и конфискация имущества каждого хозяйства в отдельности осуществлялись только после утверждения окружным исполкомом.

Для оперативного руководства переселением и расселением была создана областная комиссия в составе представителей облплана, областного земельного управления, областного административного отдела с привлечением заинтересованных организаций. При окрисполкомах предписывалось создать аналогичные комиссии под председательством члена президиума окрисполкома, в составе представителей окружного земельного управления и окружного административного отдела.

Внеобластное расселение «контрреволюционной и открыто враждебной части кулачества» ${ }^{27}$ производилось органами ОГПУ, а внутриобластное (крестьянских хозяйств, отнесенных к числу кулацких) - советскими административными органами.

Мероприятия органов ОГПУ осуществлялись по основным направлениям: 1) немедленная ликвидация «контрреволюционной агентуры, особенно кадров действующих контрреволюционных и повстанческих организаций, группиро-

${ }^{24}$ Государственный архив Вологодской области (ГАВО). Ф. 407. Оп. 1. Д. 98. Л. 122-123; Ф. 22. Оп. 2. Д. 10. Л. 79-79 об., 108-109.

${ }^{25}$ Коллективизация сельского хозяйства в Северо-Западном районе (1927-1937 гг.) / под ред. В.А. Ивницкого. Л.: Ленинградский государственный университет им. А.А. Жданова, 1970. С. $170-171$.

${ }^{26}$ Процедура аналогична существовавшей в Северном крае.

${ }^{27}$ Коллективизация сельского хозяйства в Северо-Западном районе... Л., 1970. С. 170171. 
вок и наиболее злостных махровых одиночек» ${ }^{28}$ (первая категория); 2) массовое выселение (в первую очередь из районов сплошной коллективизации и пограничной полосы) наиболее богатых кулаков и их семейств в отдаленные северные районы СССР и конфискация их имущества (вторая категория).

В соответствии с постановлением ЦК ВКП(б) от 30 января 1930 г. ОГПУ устанавливал по районам число лиц, подлежащих аресту. Арестованные должны были концентрироваться в окружных и областных отделах ОГПУ. Следствия по этим делам должны были рассматриваться в срочном порядке тройками по внесудебному разбирательству, которые создавались из представителей обкома ВКП(б), ОГПУ и прокуратуры. Основное количество арестованных заключалось в концлагеря. При этом, как правило, арестованный и осужденный органами ОГПУ «кулак» уже находился в концлагере, а сельсовет и райисполком еще только принимали решение о его раскулачивании и выселении. Так, например, Глеб Иванович Косов, 1867 года рождения, уроженец деревни Коротово Череповецкого района, проживавший в деревне Теплово Кадуйского сельсовета, был осужден 18 марта 1930 года тройкой ПП ОГПУ в Ленинградском военном округе по ст. 58-10 УК РСФСР к 5 годам исправильно-трудовых лагерей, а решение о его выселении было принято президиумом Кадуйского райисполкома 7 апреля 1930 года ${ }^{29}$.

Для внутриобластного расселения намечались юго-восточная часть Лодейнопольского и Ленинградского округов (районы Андомский, Ковжинский, Вытегорский, Винницкий, Оятский, Пикалевский, Копшинский и Тихвинский) и северо-восточная часть Череповецкого округа (районы Белозерский, Шольский, Вашкинский, Петропавловский и Кирилловский). Эти районы отличала небольшая численность населения, удаленность от государственной границы и главных железнодорожных магистралей. Здесь предполагалось использовать выселяемых кулаков как для работы в сельском хозяйстве, так и на лесоразработках и сплаве ${ }^{30}$. Однако, каких-либо архивных документов, свидетельствующих о претворении данных планов в жизнь, не обнаружено ${ }^{31}$.

${ }^{28}$ Г.Ф. Доброноженко, Л.С. Шабалова. Кулацкая ссылка в Коми области в первой половине 1930-х годов // Покаяние: мартиролог. Т. 4. Ч. 1. Сыктывкар: Коми книжное издательство, 2001. С. 138-142.

29 Архив УМВД России по Вологодской области (Архив УМВД России по ВО). Ф. 48. Дело о реабилитации Косова Г.И.

${ }^{30}$ Коллективизация сельского хозяйства в Северо-Западном районе... Л., 1970. С. 407.

${ }^{31}$ Архив УМВД России по ВО. Ф. 6. Оп. 1. Д. 148. Л. 119-119 об. Вместе с тем, судя по архивным документам, в Вытегорском районе выселение части крестьян, в том числе по приговорам народного суда Вытегорского района, производилось в пос. Известь Кудамозерского с/с, в Борисово-Судском районе - в пос. Каргозеро Ножемского с/с и пос. Пустынь Плосковского с/с. Однако, данные поселки в систему трудпоселений (спецпоселений) ОГПУ-НКВД Ленинградской области не входили. Фактически они представляли собой лесопункты мест- 
В 1930 году Северный край становится одним из регионов, куда в массовом порядке высылались раскулаченные крестьяне. Данный выбор не был случайным и обуславливался рядом причин. Огромный по своей площади регион, малонаселенный, но располагавший богатыми природными ресурсами, в планах форсированной индустриализации рассматривался как один из крупнейших поставщиков валюты, необходимой для промышленного строительства. Депортированные из других регионов кулаки должны были компенсировать дефицит рабочей силы и обеспечить значительный прирост объемов лесозаготовки и производства экспортной продукции. Наличие в Северном крае транспортной сети (железнодорожные и водные пути) позволяло доставить раскулаченных крестьян в места их постоянного расселения, а размеры края - рассредоточить и изолированно разместить большие массы людей ${ }^{32}$.

31 января 1930 г. на заседании бюро Северного крайисполкома был утвержден план расселения депортированных кулаков, который предусматривал размещение 70 тыс. семей (350 тыс. человек), в том числе в Архангельском округе - 30 тыс. семей, Вологодском - 10 тыс., Северо-Двинском - 9,5 тыс., Няндомском - 9,5 тыс., Коми области - 12 тыс. семей ${ }^{33}$.

Первые эшелоны с раскулаченными стали прибывать в Северный край в конце февраля 1930 года. К 20 мая в край прибыло 46562 семьи (230 065 чел.), в том числе: из Украины - 19658 семей (93 461 чел.), из ЦентральноЧерноземной области - 8237 семей (42 837 чел.), из Нижневолжского края 7981 семья (40 001 чел.), из Средневолжского края - 5566 семей (29 211 чел.), из Белорусской ССР - 4763 семьи (22 810 чел.) и Крыма - 407 семей $(1745 \text { чел. })^{34}$.

Трудоспособных мужчин сразу же направляли на строительство бараков и лесозаготовки. Женщин, стариков и детей размещали в пересыльных тюрьмах, бывших монастырях, церквях, а также во временных бараках, построенных вдоль линии железной дороги Вологда - Вятка - Котлас - Архангельск. В Вологодском округе было размещено 53357 человек, в Северо-Двинском - 54 422, в Архангельском - 44 808, в Няндомском - 13 228. Вологда с ее пригородами стала местом наибольшего скопления депортированных кулаков (42 120 чел.).

ных леспромхозов, а проживавшие в них лица под надзором органов ОГПУ-НКВД не состояли. В соответствии с приказом УНКВД СССР по Ленинградской области от 7 августа 1935 г. № 439 в подчинение Отдела лагерей, мест заключения и трудовых поселений УНКВД по Ленинградской области входили Кировская районная комендатура, поселковые комендатуры Мурманская, трудпоселков «Нивастрой», «Карелгранит», «Диабаз» и «Синявинских торфоразработок».

32 Упадымев Н.В. ГУЛАГ на Европейском Север России: генезис, эволюция, распад. Архангельск: Поморский университет, 2007. С. 69.

33 ОДСПИ ГААО. Ф. 290. Оп. 1. Д. 378. Л. 11-12.

${ }^{34}$ ОДСПИ ГААО. Ф. 290. Оп. 1. Д. 98а. Л. 115; Д. 384. Л. 15. 
Крупные партии спецпереселенцев находились в Кадникове (5 331 чел.) и Великом Устюге (3 824 чел.) $)^{35}$. Положение их было ужасным: отсутствовали нормальные жилищные условия и продовольственное снабжение, свирепствовали инфекционные заболевания, имела место массовая смертность.

В соответствии с резолюцией Северного крайкома ВКП(б) от 1 апреля 1930 г. о размещении и устройстве кулацких переселенцев в Северном крае, в основу расселения была положена сельскохозяйственная колонизация преимущественно необжитых и слабо населенных районов. Первоначально, для руководства работой по расселению и хозяйственному устройству переселенческих кулацких семей, была организована краевая комиссия при Крайисполкоме, а для практической и оперативной работы по расселению - специальное Переселенческое управление, как орган Наркомзема. На местах данной работой занимались переселенческие партии округов. На каждый поселок органами ОГПУ был назначен комендант и милиционер, которые содержались за счет государственного бюджета ${ }^{36}$.

На заседании президиума крайисполкома 3 апреля 1930 г. на обсуждение был вынесен вопрос «О плане расселения кулаков». Для продолжения работы по переселению бывших кулаков создавалась комиссия в количестве трех человек: Комиссарова (председателя крайисполкома), Шейрона (заместителя ПП ОГПУ по Северному краю) и Лютикова (начальника управления НКВД) ${ }^{37}$.

После передачи краевому исполнительному комитету всей дальнейшей работы по расселению, хозяйственному устройству, снабжению, использованию, освоению земель кулаками, за органами ОГПУ, проводившими ее до этого, были оставлены функции общего наблюдения и содействия, чекистского обслуживания и перевозки членов семей к местам постоянного поселения. Для этих целей приказом по ПП ОГПУ Северного края от 5 мая 1930 г. № 32/20 при Полномочном Представителе ОГПУ была сформирована тройка из сотрудников секретного, экономического и информационного отделов, в окружных отделах - аналогичные тройки. Этим тройкам предписывалось, «ввиду необходимости максимального использования летнего периода для отправки кулацких семей в места постоянного поселения и их хозяйственного устройства, уделить исключительно серьезное внимание: постройке жилищ в поселках, отпуску и заготовке леса, отпуску и переброске к местам построек завозного стройматериала и инструментов, отводу земель, отпуску с/х орудий, семян, заброске их на места,

${ }^{35}$ Государственный архив Архангельской области (ГААО). Ф. 621. Оп. 2. Д. 26. Л. 603.

${ }^{36}$ Коллективизация сельского хозяйства в Северном районе (1927-1937 гг.). Вологда: Северо-Западное книжное издательство, 1964. С. 318-319.

${ }^{37}$ Шашков В.Я. Раскулачивание в СССР и судьбы спецпереселенцев (1930-1954 гг.): дис. ... д-ра ист. наук. Московский государственный университет им. М.В. Ломоносова, 1995. C. 153 . 
закупке лошадей и молочного скота, снабжению продовольствием, организации медпунктов и т.д.» ${ }^{38}$. Таким образом, практически все мероприятия, проводимые местными органами исполнительной власти, оставались под официальным контролем органов ОГПУ.

По данным ОГПУ в 1930 г. в Северный край было выслано 46623 семьи (230 370 чел.), из них в порядке внутрикраевого переселения - 61 семья (305 чел.) $)^{39}$.

Новый этап раскулачивания и депортации крестьян начался весной 1931 г. Именно в этом году процесс насильственного переселения работоспособной, предприимчивой части крестьянства достиг своего апогея. Зеленый свет новым, еще более массовым, чем в 1930 г., депортациям крестьянства фактически открыло принятое 1 февраля 1931 г. Постановление ЦИК и СНК СССР «О предоставлении краевым (областным) исполкомам и правительствам союзных республик права выселения кулаков из пределов сплошной коллективизации сельского хозяйства» ${ }^{40}$.

Опыт переселения (расселения) в 1930 г. показал, что центральные партийные и советские органы, приняв решение о кулацких хозяйствах третьей категории, их экспроприации и расселении, не подкрепили его ни материальнотехнически, ни организационно. Поэтому ОГПУ предлагал всех раскулаченных водворять в спецпоселки, использовать преимущественно в отдаленных, нуждающихся в рабочей силе районах на лесо- и торфоразработках, заготовке камня, разработке апатитов, на железнодорожном строительстве ${ }^{41}$.

К этому времени ОГПУ распоряжался по своему усмотрению огромными материальными и денежными ресурсами, контролировал распределение средств, отпущенных хозяйственными организациями на нужды спецпереселенцев. Этот карательный орган превратился в экономического монстра с развитой инфраструктурой, в состав которой входили и спецпоселки для депортированных крестьян. Кроме того, ОГПУ оказывало большое влияние и на специальную комиссию во главе с А.А. Андреевым, созданную Политбюро ЦК 11 марта 1931 г. для руководства выселением и расселением раскулаченных. В ее состав входил заместитель председателя ОГПУ Г.Г. Ягода. Данной комиссией решались все вопросы, связанные с раскулачиванием, расселением и использованием раскулаченных. Затем они утверждались Политбюро, принимая силу

38 Архив УМВД России по Архангельской области (Архив УМВД России по АО). Ф. 4. Оп. 1. Д. 2. Л. 41-43.

39 Политбюро и крестьянство: высылка, спецпоселение. 1930-1940. Кн. 2 / под ред. Н.Н. Покровского. М.: РОССПЭН, 2006. С. 312.

40 Полян П.М. Не по своей воле... История и география принудительных миграций в СССР. М.: ОГИ-Мемориал, 2001. С. 70.

${ }^{41}$ Ивниц̧кий Н.A. Коллективизация и раскулачивание (начало 30-х годов). М.: Интерпракс, 1994. С. 137. 
обязательного постановления для всех органов власти и партийного руководства ${ }^{42}$.

Новая волна депортаций фактически развернулась в середине марта 1931 г. Выселение производилось с 20 марта по 25 апреля и с 10 мая по 18 сентября 1931 г., то есть с традиционным перерывом на сев. Сценарий же самого процесса оставался прежним. Сначала решение о выселении принималось группой бедноты при сельском Совете, затем оно дублировалось президиумом сельсовета, а окончательный вердикт о выселении выносился на заседании районной тройки. Полностью вся процедура занимала от 3 до 5 дней.

Анализ архивных документов показывает, что крестьяне Ленинградской области, раскулаченные весной 1931 г., направлялись на спецпоселение в Сибирь и на Дальний Восток (Алданский район Якутской АССР, Амурскую, Иркутскую и Читинскую области, Хабаровский край), где они должны были работать на золотых приисках. Судьба многих из них трагична: одни умерли еще по дороге на спецпоселение, другие - в первые месяцы и годы нахождения в спецпоселках от голода, суровых погодных условий, ужасных условий труда, эпидемий и болезней.

Крестьян Ленинградской области, раскулаченных в конце весны - начале лета 1931 г., планировалось направить на спецпоселение в Казахстан. Однако, 30 мая 1931 г. «комиссия Андреева» приняла решение о внутреннем переселении 4000 кулацких семей в северные районы Ленинградской области. 5 июня 1931 г. данное решение было утверждено соответствующим постановлением Политбюро ЦК ВКП(б) ${ }^{43}$.

Процесс выселения в июне 1931 г. ничем не отличался от предыдущих. Практически все решения о раскулачивании, принятые общими собраниями бедноты и президиумами сельских Советов, утверждались райисполкомами 2324 июня. Кулаки и члены их семей в срочном порядке были направлены на Кольский полуостров (в то время территория Ленинградской области), где уже с июля приступили к работе на строительстве каскада Нивских ГЭС (Кандалакшский район) ${ }^{44}$. Также часть из них была направлена на апатитовые и никелевые разработки и проживала в г. Хибиногорске (ныне - Кировск) ${ }^{45}$.

${ }^{42}$ Ивниикий Н.А. Коллективизация и раскулачивание... М., 1994. С. 169.

${ }^{43}$ Адибеков Г.М. Спецпереселенцы - жертвы «сплошной коллективизации». Из документов «особой папки» Политбюро ЦК ВКП(б). 1930-1932 гг. // Исторический архив. 1994. № 4. C. $157-159$.

44 Архив УМВД России по ВО. Ф. 48. Дела о реабилитации семей Басковых, Воробьевых, Прозоровых и др.

45 В сентябре 1941 г. часть депортированных (1 259 чел.) была эвакуирована в г. УстьКаменогорск Восточно-Казахстанской области Казахской ССР (Государственный архив Восточно-Казахстанской области. Ф. 462. Оп. 4. Д. 1. Л. 1-18; Архив УМВД России по ВО. Ф. 48. Оп. 1. Д. 38. Л. 31). 
В 1931 г. в Северном крае также была проведена крупномасштабная операция по выселению раскулаченных крестьян из южных районов в северные. 11 февраля 1931 г. бюро Северного крайкома ВКП(б) приняло постановление о выселении 3000 кулацких семей (I и II категорий) из основных молочноживотноводческих и льноводческих районов, а также из районов с высоким процентом коллективизации ${ }^{46}$. В апреле 1931 г. Политбюро ЦК ВКП(б) согласилось с Севкрайисполкомом и санкционировало проведение операции по выселению кулацких семей. Для проведения организационной работы по раскулачиванию и выселению при Севкрайкоме ВКП(б) была создана специальная краевая комиссия по ликвидации кулачества, в состав которой вошли председатель Севкрайисполкома и представители от краевого земельного управления, краевой прокуратуры, суда и ОГПУ.

В середине апреля комиссия приняла инструкцию по выселению контрреволюционных кулацких семей в Северном крае, в которой были определены разверстка выселяемых семей, календарные сроки и намечены места их расселения в отдаленных районах края. Всего предполагалось выселить 2750 хозяйств (из Емецкого района - 26, Каргопольского - 53, Онежского - 35, ПавлиноВиноградовского - 71, Приморского - 64, Холмогорского - 200, Шенкурского 68 , Вологодского - 170, Вожегодского - 127, Верховажского - 25, Вельского 36 , Грязовецкого - 186, Кокшенгского - 41, Кубено-Озерского - 125, Леденгского - 54, Свердловского - 140, Сямженского - 30, Толшменского - 71, Тотемского - 66, Усть-Кубинского - 120, Харовского - 120, Чебсарского - 90, Шуйского - 83, Великоустюгского - 150, Вохомского - 103, КичменгскоГородецкого - 130, Котласского - 144, Лальского - 37, Никольского - 133, Опаринского - 26, Подосиновского - 51, Рослятинского - 20, Черевковского 40 , Вилегодского - 24 семьи). По-видимому, остальные 250 хозяйств планировалось выселить из южных районов Коми области ${ }^{47}$.

Во второй половине апреля в план расселения были внесены уточнения. В Мезенский, Лешуконский и Каргопольский районы выселялись кулаки из 5 северных районов Вологодского оперсектора и 11 южных районов Котласского оперсектора. В Удорский, Усть-Цилемский, Сторожевский и Усть-Куломский районы выселялись раскулаченные из 13 южных районов Вологодского оперсектора. Семьи раскулаченных крестьян из остальных районов выселялись на Печору - в Усть-Цилемский и Ижемский районы ${ }^{48}$.

${ }^{46}$ ОДСПИ ГААО. Ф. 296. ОП. 1. Д. 381. Л. 38-39.

47 Доброноженко Г.Ф., Шабалова Л.С. Кулацкая ссылка в Коми области... Сыктывкар, 2001. С. 47-48.

48 Доброноженко Г.Ф., Шабалова Л.С. Кулацкая ссылка в Коми области... Сыктывкар, 2001. C. 47-48. 
По данным ОГПУ в 1931 г. в Северный край было выслано 11648 семей (55 239 чел.), в том числе в порядке внутрикраевого переселения 3000 семей (15 000 чел.) $)^{49}$. Фактически же на момент завершения операции по внутрикраевому переселению кулацких хозяйств (август 1931 г.) из намеченных к высылке 3 тыс. семей было выселено чуть более 1,3 тыс., т.е. вдвое меньше. Полномочное представительство ОГПУ по Северному краю отмечало невозможность высылки в полном объеме, поскольку около 1 тыс. хозяйств скрылись с мест своего проживания, а более 1 тыс. хозяйств не имели в своем составе трудоспособных членов и потому не подлежали высылке ${ }^{50}$.

Летом 1931 г. произошли существенные изменения в функционировании системы спецпоселений для депортированных крестьян. Почти годичный опыт использования высланных кулаков показал, что хозяйственные органы оказались не способны наладить работу в такой «специфичной» для них сфере деятельности. Поэтому приказом ОГПУ № 285/162 от 3 июня 1931 г. все существующие хозяйственные и административные аппараты (комендатуры, спецпоселки) в районах вселения кулаков были переданы в ведение ОГПУ. Руководство всей работой в них возложено на ГУЛАГ, в составе которого появился отдел по спецпереселенцам (ОСП), аналогичные отделы были созданы и в ПП ОГПУ на местах ${ }^{51}$.

Первоначально приказом от 8 июня 1931 года № 161/60 в составе ПП ОГПУ Северного края была организована группа по хозяйственно-административному и организационному обслуживанию спецпереселенцев и ссыльных. Соответствующий отдел был сформирован приказом ПП ОГПУ Северного края от 22 июня 1931 года № 191/73 52 .

В каждом поселке предусматривалось в среднем размещать 100 семей. Административное управление поселком осуществлял специально назначенный комендант, в помощь которому придавалось от 2 до 5 стрелков охраны. Районному аппарату ОГПУ была придана дополнительная должность районного ин-

${ }^{49}$ Политбюро и крестьянство... М., 2006. С. 312.

${ }^{50}$ Политбюро и крестьянство... М., 2006. С. 1038.

${ }^{51}$ Кокурин А.И., Петров Н.В. ОГПУ (1929-1934 гг.) // Свободная мысль - ХХІ. 1998. № 8. C. 102 .

52 Архив УМВД России по АО. Ф. 4. Оп. 1. Д. 4. Л. 87, 92. В соответствии с приказом НКВД СССР № 0044 от 21 августа 1934 г. «О структурном построении и подчинении органов НКВД», отдел по спецпереселенцам бывшего ПП ОГПУ Северного края был переименован в Отдел трудовых поселений УНКВД по Северному краю (с декабря 1936 года - Северной области) (Кокурин А.И., Петров Н.В. ГУЛАГ: структура и кадры // Свободная мысль XXI. 1999. № 8. С. 116). До 1 сентября 1944 г. весь аппарат содержался за счет 5 \% отчислений с заработной платы трудпоселенцев, занятых в хозяйственных организациях (до августа 1931 г. эти отчисления составляли 25 \%, до февраля 1932 г. - 15 \%) (Архив УМВД России по ВО. Ф. 24. Оп. 1. Д. 1. Л. 49). 
спектора по спецпереселенцам, его помощника и делопроизводителя. Они обеспечивали систематический контроль за использованием спецпереселенцев на хозяйственных работах, их бытовое и чекистское обслуживание и правильный учет.

25 октября 1931 г. было утверждено «Временное положение о правах и обязанностях спецпереселенцев, об административных функциях и административных правах поселковой администрации в районах расселения спецпереселенцев» ${ }^{53}$. В соответствии с данным положением на комендатуры ОГПУ, кроме специальных оперативных и хозяйственных функций, возлагались и административные функции. Кроме того, им предоставлялись широкие права. Комендатуры вырабатывали правила внутреннего распорядка поселка в зависимости от его величины, хозяйственных задач и признаков; закрепляли за определенными домами определенные семьи (лиц), вели их точный поименный учет, производили контроль за наличием; определяли выбор места и характер работ спецпереселенцев, подчиненных данной комендатуре; давали разрешение на использование спецпереселенцев на тех или иных видах хозяйственных работ; принимали заявления, жалобы и просьбы от спецпереселенцев, разбирали их на месте и разрешали в пределах своей компетенции; отвечали за политический и общественный порядок в спецпоселках. В случае нарушения внутреннего распорядка комендатуры имели право на административные меры взыскания в отношении спецпереселенцев - подвергать аресту или денежному штрафу, переводить на менее удобные и хуже оплачиваемые работы, переводить в другие поселки.

К 1933 г. численность спецпоселенцев заметно превосходила численность заключенных в лагерях ОГПУ, вследствие чего возникла идея серьезной реорганизации управления местами заключения и спецпоселениями системы ОГПУ. Предполагалось создать самостоятельное Главное управление трудовыми спецпоселениями (ГУТС) ОГПУ. Приказом по УД ОГПУ № 48 от 27 февраля 1933 г. был даже введен временный штат ГУТС (250 человек), однако в дальнейшем это не привело к новым кадровым назначениям. В итоге, отдел спецпоселений, так же как и органы на местах, остался в структуре ГУЛАГа (последний до 1934 г. входил в систему ОГПУ, с 1934 г. - в систему НКВД) $)^{54}$.

Взамен этого 17 апреля 1933 г. было принято Постановление ЦК ВКП (б) «Об организации трудовых поселений ОГПУ», оформленное Постановлением СНК СССР № 775/146с от 20 апреля. Эти документы предписывали, во-первых, возложить на ОГПУ организацию трудовых поселений, по типу существующих спецпоселков, для размещения в них и хозяйственного освоения вновь пересе-

53 Спецпереселенцы в Западной Сибири: весна 1931 - начало 1933 года / под ред. В.П. Данилова и С.А. Красильникова. Новосибирск: ЭКОР, 1993. С. 68-74.

${ }^{54}$ Кокурин А.И., Петров Н.В. ОГПУ (1929 - 1934 гг.) // Свободная мысль - ХХІ. 1998. №8. C. 107. 
ляемых контингентов; во-вторых, реорганизовать Главное управление лагерей ОГПУ в Главное управление лагерей и трудовых поселений ОГПУ; в-третьих, осуществлять трудовое использование выселяемых контингентов путем организации в местах расселения сельского хозяйства, рыболовства, кустарных промыслов и других видов хозяйственной деятельности; в-четвертых, возложить на ОГПУ организацию жилищного, культурно-бытового и санитарномедицинского строительства в трудовых поселениях и обеспечения их всеми видами снабжения (продовольствие, промтовары, сельскохозяйственное оборудование, инвентарь и пр.); в-пятых, обязать наркоматы и хозорганы, обслуживающие спецпоселки старого расселения, до мая месяца передать ОГПУ весь аппарат, занятый обслуживанием спецпереселенцев; в-шестых, контингент вновь переселяемых приравнять во всех отношениях к спецпереселенцам, расселенным в 1930-1931 гг. и т.д. ${ }^{55}$

В 1932-1933 гг. раскулачивание крестьянских хозяйств и высылка на спецпоселение осуществлялись, как правило, в индивидуальном порядке - в порядке исключения или в виде чистки колхозов от кулацких элементов и саботажников. Так, в первую половину 1932 г. в Северный край было выслано 3260 кулаков $^{56}$, в 1933 году -16659 кулаков ${ }^{57}$.

Формально по Конституции 1936 г. спецпоселенцы получили гражданские права, однако они не могли покинуть мест высылки ${ }^{58}$. Репрессии против крестьян («бывших кулаков») не прекратились и после принятия Конституции 1936 г., которая провозгласила победу социализма в СССР.

В 1937-1938 гг. по Вологодской области, как и по всей стране, прокатился маховик «Большого террора». Как известно, репрессии разворачивались по двум направлениям: первое - так называемая «кулацкая» операция, второе операции «по инонациональностям» (полякам, немцам, финнам, грекам, болгарам, литовцам, румынам и др.). На основании решений специально созданных внесудебных органов - двоек, троек, - особых троек выносились приговоры, содержание которых было заранее определено ${ }^{59}$.

${ }^{55}$ Кокурин А.И., Петров Н.В. ГУЛАГ: структура и кадры // Свободная мысль - ХХІ. 1999. № 8. С. 116.

56 До 1934 г. они назывались спецпереселенцами, в 1934-1944 гг. - трудпоселенцами, с марта 1944 г. - спецпереселенцами контингента «бывшие кулаки».

57 Земсков В.Н. Судьба «кулацкой ссылки» (1930-1954 гг.) // Отечественная история. 1994. № 1. C. 122.

58 Только после войны, в 1946-1954 гг., все ограничения с депортированных крестьян были сняты. Однако, ни о какой реабилитации их, как политически репрессированных, не могло быть и речи.

59 Подробнее о подготовке и проведении массовых операций НКВД, деятельности тройки УНКВД по Вологодской области, Комиссии НКВД и Прокурора СССР, особой тройки УНКВД по Вологодской области см.: Кузьминых А.Л., Старостин С.И. Поляки в Вологод- 
При организации и проведении «кулацкой операции» все репрессируемые были разбиты на две категории. К первой категории относились «наиболее враждебные элементы», которые подлежали немедленному аресту и по рассмотрении их дел на тройках - расстрелу. Ко второй категории - «менее активные враждебные элементы». Они подлежали аресту и заключению в лагеря на срок от 8 до 10 лет, а наиболее злостные и социально опасные из них - заключению на те же сроки в тюрьмы, по определению тройки. Тройки вели протоколы своих заседаний, в которых записывали вынесенные ими приговоры в отношении каждого осужденного. Протоколы заседаний направлялись начальникам оперативной группы для приведения приговоров в исполнение. Как правило, приговоры выносились заочно - без вызова обвиняемого, без участия защиты и обвинения, и обжалованию не подлежали. Приговоры к расстрелу приводились «с обязательным полным сохранением в тайне времени и места приведения приговора в исполнение» ${ }^{60}$.

Одновременно с началом массового террора в стране проходили административно-территориальные преобразования. 23 сентября 1937 г. постановлением Центрального Исполнительного Комитета СССР Северная область была разделена на Вологодскую и Архангельскую области. В соответствии с приказом НКВД СССР № 00623 от 29 сентября 1937 г. было организовано Управление НКВД СССР по Вологодской области, в состав которого вошли: 2 районных отдела и 21 районное отделение из расформированного УНКВД по Северной области и 18 районных отделений, переданных из подчинения УНКВД по Ленинградской области ${ }^{61}$. Дальнейшее проведение «кулацкой» операции перешло к вновь сформированному управлению НКВД и тройке, в составе председателя Жупахина (начальник УНКВД) и членов Люстрова (2-й секретарь обкома ВКП(б) и Савгирова (заместитель прокурора Вологодской области по спецделам).

Тройка УНКВД по Вологодской области приступила к своей работе 2 ноября 1937 г. и завершила ее 22 сентября 1938 г. Всего на основании ее решений было репрессировано 4705 чел.: 2090 чел. (44,4 \%) приговорено к расстрелу, 2615 чел. $(55,6 \%)$ - к заключению в ИТЛ, из них по обвинению в контрреволюционных преступлениях - 4524 чел. (96,2 \%), из которых более 4000 чел. в протоколах тройки значились как «бывшие кулаки». Как уголовный элемент был репрессирован 181 чел. $(3,8 \%)^{62}$.

ской области: репрессии, плен, спецпоселение (1937-1953 гг.). Вологда: Древности Севера, 2014. С. 23-33.

${ }^{60}$ ГУЛАГ: Главное управление лагерей. 1918-1960 / под ред. А.Н. Яковлева; сост. А.И. Кокурин, Н.В. Петров. М.: МФД, 2000. С. 98, 103.

${ }^{61}$ Архив УМВД России по ВО. Ф. 6. Оп. 1. Д. 195. Л. 54-55 об.

${ }^{62}$ Архив УФСБ России по ВО. Ф. 10. Оп. 1. Д. 1, 3, 5, 7, 9, 11, 13, 15, 17, 19, 21, 23, 25, 27, 29, 31, 33, 54, 56, 60, 62, 64, 65, 67, 71. 
Естественно, в число репрессированных «бывших кулаков» попали и крестьяне, высланные на территорию Вологодской области в 1930-1933 гг. Всего тройкой УНКВД по Вологодской области в «кулацкую операцию» были репрессированы 135 трудпоселенцев, из которых 44 чел. приговорены к расстрелу, 91 чел. - к заключению в ИТЛ сроком на 10 лет.

При проведении операций этнического характера - против поляков, немцев, румын, латышей, эстонцев, финнов, греков, афганцев, иранцев, китайцев, болгар, македонцев и харбинцев ${ }^{63}$, которые рассматривались сталинским руководством как потенциальный ресурс для шпионажа и коллаборационизма ${ }^{64}$, был создан так называемый «альбомный» порядок осуждения. После окончания следствия на обвиняемого составлялась справка «с кратким изложением следственных и агентурных материалов, характеризующих степень виновности арестованного». Отдельные справки собирались, перепечатывались в виде списка, который представлялся на рассмотрение комиссии из двух человек - начальника УНКВД и прокурора («двойки»), в задачу которых входило отнесение обвиняемого к одной из двух категорий ${ }^{65}$ : первой (расстрел) или второй (заключение на срок от 5 до 10 лет). Затем список отсылался в Москву на рассмотрение и окончательное утверждение Комиссии НКВД и Прокурора СССР (Н.И. Ежова и А.Я. Вышинского). После утверждения список возвращался в Управление НКВД по Вологодской области с копией протокола Комиссии. Начальнику УНКВД предписывалось немедленно привести в исполнение приговоры на лиц, приговоренных к расстрелу, а дела на них, со справками об исполнении приговора, выслать в Москву. На лиц, приговоренных к заключению в ИТЛ, направлялись выписки из постановлений Особого Совещания при НКВД СССР, дела на них также высылались в Москву ${ }^{66}$. В ведение УНКВД по Вологодской области входило также исполнение постановлений Комиссии НКВД и Прокурора СССР по «альбомам», направленным в Москву Дорожно-транспортным отделом ГУГБ НКВД Северной железной дороги (ДТО ГУГБ НКВД СЖД).

Всего в ходе «национальных» операций по делам УНКВД по Вологодской области, представленным в Москву, были рассмотрены материалы по обвинению «в шпионской и диверсионной деятельности» в отношении 290 чел., из которых 221 чел. - осуждены к высшей мере наказания, 66 чел. - к 10 годам ИТЛ, в отношении 1 чел. дело передано на рассмотрение Военной Коллегии Верховного Суда СССР, в отношении 2 чел. - в суды общей юрисдикции ${ }^{67}$. При этом,

${ }^{63}$ К их числу относили бывших сотрудников Китайско-Восточной железной дороги, вернувшихся в СССР после ее продажи в 1935 г.

${ }^{64}$ Хлевнюк О.В. Большой террор 1937-1938 гг. как проблема научной историографии // Историческая наука и образование на рубеже веков. М.: Собрание, 2004. С. 438.

${ }^{65}$ Как и при «кулацкой операции».

${ }^{66}$ Архив УФСБ России по ВО. Ф. 10. Оп. 1. Д. 34, 35.

${ }^{67}$ Архив УФСБ России по ВО. Ф. 10. Оп. 1. Д. 34. 
все 22 чел., репрессированные в ходе «греческой» операции были крестьянами, депортированными в Вологодскую область в 1930 г. из Украинской ССР и Крыма, а 14 из 31 чел., репрессированных в ходе «румынской» операции трудпоселенцацми-кулаками, проживавшими в Харовском районе Вологодской области. В то же время, по делам ДТО ГУГБ НКВД СЖД были рассмотрены материалы в отношении 239 чел., из которых 100 чел. были осуждены к ВМН, 112 чел. - к 10 годам ИТЛ, 9 чел. - к 8 годам ИТЛ, 3 чел. - к 5 годам ИТЛ. В отношении 7 чел. дела были переданы на рассмотрение Военной Коллегии Верховного Суда СССР, в отношении 2 чел. - в Линейный суд СЖД, в отношении 6 чел. - направлены на доследование ${ }^{68}$. При этом, 11 из 14 чел., репрессированных в ходе «немецкой» операции, являлись крестьянами, высланными в 1930 году в Северный край из Украинской ССР.

С весны 1938 г. операции по национальным «линиям» стали основным направлением в массовых репрессиях. Однако, к сентябрю 1938 г. в Центральном аппарате НКВД СССР нерассмотренными оставались «альбомы» по национальным линиям на 126 тысяч человек. С августа 1938 г. было запрещено оформлять дела «в альбомном порядке». Для рассмотрения оставшихся нерассмотренными дел на арестованных по «контрреволюционным национальным контингентам» приказом НКВД СССР № 00606 в каждой области, крае или республике были созданы «особые тройки», в состав которых входили начальник УНКВД, первый секретарь обкома ВКП(б) и областной прокурор. Рассматривать дела они должны были только на тех, кто в рамках национальных операций был арестован до 1 августа 1938 г. Срок их работы определялся в два месяца. Немедленно следом за приказом № 00606 на места были возвращены все «альбомы» 69.

Особая тройка УНКВД по Вологодской области рассматривала дела как самого УНКВД, так и Дорожно-транспортного отдела (ДТО) СЖД. Она начала и завершила свою «работу» в течение октября 1938 г. За указанный период были рассмотрены дела по всем национальным «линиям» на 916 человек: 294 чел. приговорены к расстрелу, 465 чел. - к 10 годам ИТЛ, 46 чел. - к 8 годам ИТЛ, 13 чел. - к 5 годам ИТЛ. В отношении 71 чел. - дела направлены в Военный трибунал, 21 чел. - в Особое Совещание при НКВД СССР, 6 чел. - на доследование. Как и прежде, в число репрессированных попали и трудпоселенцыкулаки (150 чел.), из которых 77 чел. приговорены к ВМН, 69 чел. - к 10 годам ИТЛ, 1 чел. - к 8 годам ИТЛ. В отношении 3 человек дела были переданы на рассмотрение Военного трибунала. Из числа репрессированных по «болгар-

${ }^{68}$ Архив УФСБ России по ВО. Ф. 10. Оп. 1. Д. 34. Л. 42-45, 56-59; Д. 35.

${ }^{69}$ Охотин Н., Рогинский А. Из истории «немецкой операции» НКВД 1937-1938 гг. // Репрессии против российских немцев. Наказанный народ. М.: Звенья, 1999. С. 61-62. 
ской» линии (24 чел.) все являлись депортированными крестьянами, по «греческой» линии таковыми являлись 13 чел., по «немецкой» - 112 чел.

17 ноября 1938 г. все «массовые операции» были завершены, деятельность созданных в 1937-1938 гг. «троек», «особых троек», а также Комиссии НКВД и Прокурора СССР («альбомный порядок») официально прекращена. Далее решения по всем следственным делам, как и до августа 1937 г., должны были выноситься или судебными органами, или Особым Совещанием при НКВД $\mathrm{CCCP}^{70}$.

Крестьяне, находившиеся в «кулацкой ссылке» в других регионах страны, также оказались репрессированы в ходе «кулацкой операции». Так, более 50 чел., находившихся на спецпоселении в Кандалакшском районе Мурманской области, в 1937-1938 гг. были приговорены к $\mathrm{BMH}^{71}$.

В связи с образованием Вологодской области, функции по административно-хозяйственному обслуживанию трудпоселенцев были возложены на Отдел мест заключения и трудовых поселений УНКВД по Вологодской области, с 1 января 1939 г. - Отдел исправительно-трудовых колоний, исправительных работ и трудовых поселений УНКВД по Вологодской области. В районах, отошедших к Вологодской области из Ленинградской области, трудпоселенцев не находилось. На 1 июля 1938 г. на спецпоселении в Вологодской области находилось 9606 человек, размещенных в 45 поселках, обслуживаемых 8 комендатурами $^{72}$.

Необходимо отметить, что в период до 1941 г. некоторым спецпереселенцам из числа молодежи, отличившимся в работе на производстве и активно участвовавшим в общественной жизни, лояльно относившимся к мероприятиям со-

70 Данное решение было принято на основании постановления СНК СССР и ЦК ВКП(б). Приказом НКВД СССР от 26 ноября 1938 г. № 0062 приказы, циркуляры и распоряжения НКВД о проведении всех операций были признаны утратившими силу или отменены. Однако сами репрессии были продолжены. По данным Управления ФСБ России по Вологодской области всего в 1937-1940 гг. областным Управлением НКВД было арестовано 10405 чел. См. подробнее: Доверено охранять Отечество. (Из истории органов безопасности в Вологодском крае) / под ред. М.А. Безнина. Вологда: Вологодский государственный педагогический университет, 2008. С. 302.

${ }^{71}$ Подсчитано автором по Книге памяти: Российская Федерация, Мурманская область. Поименный список репрессированных жителей Кольского полуострова, а также иностранных граждан, проживавших в Мурманской области / сост. С.Н. Дащинский, В.В. Воронин, В.А. Нечушкин. Мурманск: Север, 1997. С. 13, 16, 19, 31, 35, 38, 43, 47, 55, 63, 66, 71, 76, 78, 80, 81, 89, 94, 96, 98, 103, 107, 109, 117, 123, 126, 132, 138, 139, 150, 151, 154, 159, 160, 164, $165,169,171,186,200,201,203,205,207,209,210,219,223,224,227,228,242,244,251,252$, 258, 263, 266, 272-275, 278, 285, 295, 299-300, 304, 311, 317, 323, 326, 328, 335-338, 340, 350, 353, 359, 364, 368-369, 379.

72 Земсков В.Н. Судьба «кулацкой ссылки» (1930-1954 гг.) // Отечественная история. 1994. № 1. C. 126. 
ветской власти, были предоставлены гражданские права. При этом часть их, довольно незначительная, смогла уехать из спецпоселков на учебу в средние и высшие учебные заведения.

Начало Второй мировой войны и раздел Польши между Германией и Советским Союзом дали новый толчок к расширению спецссылки за счет новых категорий спецпереселенцев. В 1940-1941 гг. около 320 тысяч польских граждан - жителей захваченных Советским Союзом восточных территорий довоенного польского государства и беженцев из Центральной Польши, оккупированной Германией, - были депортированы советскими органами в глубь СССР.

На территориях Республики Польша, занятых Советским Союзом в сентябpe 1939 г., были образованы пять западных областей Белорусской ССР (Вилейская, Барановичская, Белостокская, Брестская и Пинская) и шесть областей Украинской ССР (Волынская, Ровенская, Львовская, Тарнопольская, Дрогобычская и Станиславская). В 1940 г. советские власти осуществили три крупномасштабные операции по высылке жителей западный областей УССР и БССР в отдаленные северные и восточные районы СССР. Польские граждане ${ }^{73}$, депортированные в ходе каждой из этих операций, составили в учетах НКВД три отдельных категории: спецпереселенцы-осадники (140-141 тыс. человек, высылка 10 февраля 1940 г.); административно-высланные «члены семей репрессированных» (61 тыс. человек, высылка 13 апреля 1940 г.); спецпереселенцыбеженцы (78-79 тыс. человек, высылка 29 июня 1940 г. $)^{74}$.

Четвертая операция по высылке в глубь СССР, охватившая жителей Молдавской, Литовской, Латвийской и Эстонской ССР, а также западных областей УССР и БССР, была проведена в мае-июне 1941 г. Высланные составили в учетах НКВД категорию ссыльнопоселенцев. Число польских граждан среди них можно оценить в 34-44 тыс. человек ${ }^{75}$.

Депортированные польские граждане содержались на спецпоселении в 13 областях, 2 краях и 4 автономных республиках РСФСР, а также в 8 областях

73 К репрессированным в 1939-1941 гг. жителям восточных территорий довоенного польского государства применяется термин «польские граждане» или «польские спецпереселенцы» вне зависимости от их национальности и не вне их государственной принадлежности, которая в годы войны стала предметом спора между польским правительством в изгнании и советскими властями, отказывавшимися считать этих лиц иностранцами.

${ }^{74}$ Gurjanow A. Cztery deportacje 1940-41// KARTA: Niezależne pismo historyczne (Warszawa). 1994. Nr. 12. S. 114-136; Гурьянов A.Э. Польские спецпереселенцы в СССР в 19401941 гг. // Репрессии против поляков и польских граждан / сост. А.Э. Гурьянов. М.: Звенья, 1997. C. 114-136.

75 Гурьянов А.Э. Масштабы депортации населения в глубь СССР в мае-июне 1941 г. // Репрессии против поляков и польских граждан / сост. А.Э.Гурьянов. М.: Звенья, 1997. C. $137-175$. 
Казахской $\mathrm{CCP}^{76}$. Те из них, кого разместили в Вологодской области ${ }^{77}$, относились лишь к двум из четырех вышеперечисленных категорий - к спецпереселенцам-осадникам и спецпереселенцам-беженцам ${ }^{78}$.

Выселение семей осадников и лесников ${ }^{79}$ было проведено в один день 10 февраля 1940 г., одновременно во всех западных областях УССР и БССР. В тот же день первые железнодорожные эшелоны со спецпереселенцами начали отправляться в глубь СССР. Прибывшие в конце феврале - начале марта 1940 г. спецпереселенцы-осадники (более 7800 чел.) были расселены в

76 Гурьянов А. Польские спецпереселенцы в Сибири (1940-1941) // Сибирь в истории и культуре польского народа / сост. А. Кучинский и П.С. Романов. М.: Ладомир, 2002. С. 368 375.

77 Подробнее об истории нахождения польских спецпереселенцев на территории Вологодской области в 1940-1946 гг. см.: Кузьминых А.Л., Старостин С.И. Поляки в Вологодской области... Вологда, 2014. С. 300-327.

${ }^{78}$ Подробнее о процессе принятия решений о депортации осадников и беженцев, разработке проведения этих высылок и их результатах см.: Бугай Н.Ф. Иосиф Сталин - Лаврентию Берии: «Их надо депортировать...»: Документы, факты, комментарии. М.: Дружба народов, 1992; Гурьянов А.Э. Польские спецпереселенцы в СССР. М.: Звенья, 1997; Гурьянов А. Введение // Польские спецпереселенцы в Архангельской области. Ч. 1. Алфавитный список 9320 польских граждан, высланных в 1940 г. из Белостокской области / сост. Э. Рыбарска, А. Гурьянов, А. Рачинский и Т. Лозинская. Варшава, 2003. С. 756-773; Ч. 2. Алфавитный список 8559 польских граждан, высланных в 1940 г. из Барановичской и Вилейской областей. Индекс репрессированных. Вып. XIV / сост. Э. Рыбарска, А. Гурьянов, А. Рачинский и Т. Лозинская. Варшава, 2004. С. 718-738; Лебедева Н.С. Введение // Катынь: Пленники необъявленной войны: документы и материалы / под ред. Р.Г. Пихои, А. Гейштора. М.: Демократия, 1999. С. 29-30.

79 «Военными осадниками» в Польше называли колонистов из числа демобилизованных военнослужащих польской армии, участников польско-советской войны 1919-1920 гг., бесплатно получивших от польского государства земельные наделы в северо-восточных и восточных воеводствах - Виленском, Новогрудском, Белостокском, Полесском и Волынском. Их поселения - «осады» - находились по соседству с белорусскими или украинскими селами, население которых относилось к осадникам настороженно, а зачастую и враждебно. На восточных территориях Республики Польша (включая юго-восточные воеводства - Львовское, Тарнопольское и Станиславовское) были еще и «гражданские осадники», выкупившие у государства заброшенные земельные участки на льготных условиях. К ним относились как колонисты, прибывшие из других районов Польши, так и местные крестьяне, увеличившие таким образом свои прежние владения. Операция по выселению семей осадников охватила также и «лесников» - работников «сторожевой охраны лесов» вместе с их семьями. На поселении всех их причисляли к категории спецпереселенцев-осадников.

Категория спецпереселенцев-беженцев включала в себя жителей захваченной Германией части Польши, бежавших на территорию западных областей Украины и Белоруссии после 1 сентября 1939 г., а затем изъявивших желание выехать из СССР на территорию, занятую немцами, но не принятых германским правительством и вскоре высланных в северные и восточные районы Советского Союза. 
12 спецпоселках, расположенных в 7 районах Вологодской области ${ }^{80}$. Вскоре (предположительно в апреле 1940 г.) к ним добавился еще один - спецпоселок Явенга (Явенгский), куда была переведена часть спецпереселенцев из спецпоселков Зеленоборский и Жаровский Вожегодского района ${ }^{81}$. Первоначально в Явенгском мехлесопункте (МЛП) планировалось разместить добровольных переселенцев из западных областей Украины и Белоруссии, в основном беженцев, завербованных представителями треста «Вологдалес» для работы на лесозаготовках ${ }^{82}$. Однако завербованных приехало гораздо меньше, чем предполагалось, а поселки спецпереселенцев-осадников, особенно Зеленоборский, оказались переполненными ${ }^{83}$. По-видимому в связи с этим, завербованных перевели в другие леспромхозы и лесопункты треста «Вологдалес», а в Явенгский МЛП переместили спецпереселенцев-осадников.

Следующая волна депортированных польских граждан поступила в Вологодскую область в первой половине июля 1940 г. Значительное большинство в ней составляли спецпереселенцы-беженцы. Операция по их выселению была проведена 29 июня 1940 г., одновременно во всех западных областях УССР и БССР. Одновременно с беженцами в Вологодскую область прибыла крупная группа спецпереселенцев-осадников, которые по тем или иным причинам не были депортированы в ходе основной операции по высылке осадников 10 февраля 1940 г.

Для размещения спецпереселенцев-беженцев в Вологодской области были заранее организованы 14 спецпоселков: Потеряха и Вожемка в Нюксенском районе, Комарица и Чуриловский в Тотемском районе, Полдарский и Терехино

${ }^{80}$ Архив УМВД России по ВО. Ф. 29. Оп. 2. Д. 18. Л. 2-19, 21-54, 56-82, 84-98, 100-161.

${ }^{81}$ Приказ об организации спецпоселка Явенга (Явенгский) не обнаружен. В архивных личных делах основной массы спецпереселенцев, находившихся в этом спецпоселке, в качестве даты прибытия указано 24 февраля 1940 г. Поскольку все спецпереселенцы-осадники, прибывшие с основной волной и затем содержавшиеся в этом спецпоселке, по состоянию на 15-16 марта 1940 г. находились в спецпоселках Зеленоборский или Жаровский (Архив УВМД России по ВО. Ф. 29. Оп. 2. Д. 18. Л. 56-82), можно заключить, что 24 февраля 1940 г. они прибыли именно в эти два спецпоселка, а спецпоселок Явенга был организован позже, между 25 марта 1940 г. - датой смерти в спецпоселке Зеленоборский спецпереселенцаосадника Мороза Николая, чья семья впоследствии попала в спецпоселок Явенга, и 4 мая 1940 г. - датой рождения в спецпоселке Явенга двух детей (вскоре умерших) в семье спецпереселенцев-осадников Муха.

82 По-видимому, именно завербованные подразумевались в спецсообщении начальника УНКВД по ВО П.П. Кондакова от 21 марта 1940 г., упоминавшем о прибытии в Вологодскую область (одновременно со спецпереселенцами) 2004 беженцев.

${ }^{83}$ ГАВО. Ф. 1727. Оп. 2. Д. 1240. Л. 231, 239-240 об. О кампании по вербовке беженцев, находившихся в западных областях УССР и БССР, на работу на предприятиях в восточных областях см. также: Гурьянов А. Введение // Польские спецпереселенцы в Архангельской области... Ч. 1. С. 757-758; Ч. 2. С. 719-720; Ч. 3. С. 811-812. 
в Велико-Устюгском районе, Муржа в Никольском районе, Стеклянка в Лежском районе, Ужла в Ковжинском районе, Ялегский в Андомском районе, Мегорский и Коштугский в Оштинском районе, Иткольский в Кирилловском районе и Ковжезаводской в Шольском районе. Вселение спецпереселенцевбеженцев в спецпоселки началось 6 июля и завершилось 13 июля 1940 г.

Для размещения дополнительно прибывших в июле спецпереселенцевосадников были организованы три новых спецпоселка: Ветка в Вытегорском районе, Средняя Шима в Ковжинском районе и Турнега в Андомском районе. Вселение в эти спецпоселки происходило, в основном, 10 и 15 июля 1940 г.

Еще одно место содержания спецпереселенцев в Вологодской области появилось в связи с тем, что в составе семей депортированных польских граждан прибыло много нетрудоспособных (стариков и инвалидов), ставших серьезной обузой как для лесозаготовительных организаций, так и для органов НКВД. Решением Совнаркома РСФСР Вологодскому облисполкому и Народному комиссариату социального обеспечения РСФСР было предложено организовать в Вологодской области дом для инвалидов-польских граждан на 300 мест. Выполняя это предложение, суженное заседание Вологодского облисполкома 13 августа 1940 г. решило организовать дом для инвалидов в Семигороднем сельсовете Харовского района. Инвалидов из числа польских граждан начали принимать в Харовский спецдом со 2 октября 1940 г. По состоянию на 1 января 1941 г., в нем на обеспечении числилось 102 человека, в том числе 40 женщин $^{84}$ (по другим данным 103 человека - 49 осадников и 54 беженца ${ }^{85}$ ).

В конце октября 1940 года в Вологодскую область были переселены 605 спецпереселенцев-осадников (108 семей) из спецпоселков Шарьинского района Горьковской области ${ }^{86}$. Для их размещения были организованы еще два спецпоселка - Онежский и Саминский (Десяток) в Андомском районе ${ }^{87}$.

Таким образом, к ноябрю 1940 г. в Вологодской области окончательно сформировалась система мест поселения для польских спецпереселенцев, состоявшая из 34 спецпоселков (20 - для осадников и 14 - для беженцев) и одного инвалидного спецдома, находившихся в 17-ти из 43-х существовавших тогда административных районов области ${ }^{88}$. Поселковые комендатуры спецпоселков

${ }^{84}$ ГАВО. Ф. 2491. Оп. 6. Д. 1. Л. 145-146.

${ }^{85}$ ГАРФ. Ф. 9479. Оп. 1. Д. 75. Л. 5; Д. 88. Л. 88-89.

${ }^{86}$ ГАРФ. Ф. 9479. Оп. 1. Д. 75. Л. 5-5 об.

${ }^{87}$ Приказом начальника Управления НКВД по Вологодской области № 367 от 14 октября 1940 г. (Архив УМВД России по ВО. Ф. 39. Оп. 1. Д. 1. Л. 508).

${ }^{88}$ Расположение всех спецпоселков см. на карте и в каталоге «Спецпоселки в Вологодской области. 1940-1941 гг.» (Гурьянов А., Старостин С. Введение // Польские спецпереселенцы в Вологодской области. Алфавитный список 14226 польских граждан, высланных в 1940 г. из западных областей БССР и УССР / сост. А. Дзенкевич, Э. Рыбарска, А. Гурьянов, А. Рачинский и С. Старостин. Варшава, 2005. С. 661-662, 688-693). 
Тотемского, Леденгского (переименованного в конце февраля 1941 г. в Бабушкинский), Вожегодского, Харовского, Нюксенского и Андомского районов (всего 20 спецпоселков в 6 районах) подчинялись своим районным комендатурам, а поселковые комендатуры остальных 14 спецпоселков - непосредственно ОИТК (Отделу исправительно-трудовых колоний, имевшему в своем составе Отделение трудовых поселений) областного УНКВД. Правда, Андомская райкомендатура, учрежденная в октябре 1940 г. тем же приказом начальника УНКВД по Вологодской области, что и спецпоселки Онежский и Саминский, так и не была утверждена приказом НКВД СССР, и с 3 июня 1941 г. ее пришлось сократить ${ }^{89}$.

К началу 1941 года на спецпоселении в Вологодской области находилось 13139 спец-переселенцев (осадников - 9 270, беженцев - 3 869), которые проживали в 34 спецпоселках ${ }^{90}$, еще 103 человека проживали в инвалидном доме и 20 - в детских домах (16 детей беженцев и 4 ребенка осадников) ${ }^{91}$, всего 13262 польских гражданина. Трудпоселенцев, содержавшихся в трудпоселках в Вологодской области, по состоянию на 1 января 1941 г. было заметно меньше - 9979 человек $^{92}$.

В это время по числу польских спецпереселенцев Вологодская область находилась на шестом месте после Архангельской (53 021 чел.), Свердловской (26 819 чел.), Новосибирской (19 594 чел.) областей, Коми АССР (18 722 чел.) и Красноярского края (14989 чел.) по состоянию на 1 января 1941 г. $^{93}$

Пребывание лиц, депортированных из западных областей УССР и БССР, на поселении в Вологодской области закончилось их освобождением на основании Указа ПВС СССР от 12 августа 1941 г. «О предоставлении амнистии польским гражданам, содержащимся в заключении на территории СССР» ${ }^{94}$. После применения амнистии польским гражданам было предоствлено «право свободного передвижения по территории Советского Союза, за исключением пограничной полосы вдоль всей границы СССР, режимных местностей 1-й и 2-й категории и запретной зоны и местностей объявленных на военном положении» ${ }^{95}$.

${ }^{89}$ ГАРФ. Ф. 9479. ОП. 1. Д. 75. Л. 55.

${ }^{90}$ Архив УФСБ России по ВО. Ф. 1п/х. Оп. 4. Д. 7. Л. 6 об; ГАРФ. Ф. 9479. Оп. 1. Д. 75. Л. 5.

${ }^{91}$ ГАРФ. Ф. 9479. Оп. 1. Д. 75. Л. 5; Д. 88. Л. 88, 89.

${ }^{92}$ ГАРФ. Ф. 9479. Оп. 1. Д. 62. Л. 69; Д. 88. Л. 95.

${ }^{93}$ ГАРФ. Ф. 9479. Оп. 1. Д. 62. Л. 68-69.

94 Указ ПВС СССР от 12.08.1941 г. «О предоставлении амнистии польским гражданам, содержащимся в заключении на территории СССР»: Русский архив: Великая Отечественная. СССР и Польша: 1941-1945. М.: ТЕРРА, 1994. Т. 14 (3-1). С. 24.

95 Архив УМВД России по ВО. Ф. 6. Оп. 1. Д. 429. Л. 34. 
Процесс освобождения спецпереселенцев с поселения начался 28 августа 1941 г. и практически закончился 6 октября 1941 г. ${ }^{96} 13$ февраля 1942 г. начальник УНКВД майор госбезопасности Л.Ф. Галкин ${ }^{97}$ доложил заместителю наркома внутренних дел В.Н. Меркулову, что в Вологодской области «все польские граждане, за исключением единиц, амнистированы» ${ }^{98}$.

После проведения амнистии, в соответствии с приказом НКВД СССР № 001187 от 31 августа 1941 г. $^{99}$, все районные и поселковые комендатуры НКВД по обслуживанию спецпереселенцев-осадников, лесников и беженцев были ликвидированы, а сами спецпоселки переданы в ведение местных леспромхозов.

По данным на 1 октября 1941 г., в Вологодской области продолжали находиться в трудпоселках, под надзором органов НКВД, 9880 трудпоселенцев (мужчины - 3331 чел., женщины - 3136 чел., подростки от 14 до 16 лет 823 чел., дети до 14 лет - 2590 чел.) ${ }^{100}$. По их количеству область находилась на восемнадцатом месте среди республик, краев и областей $\mathrm{CCCP}^{101}$.

Великая Отечественная война не только стала самым суровым и жестоким испытанием для нашей страны, но и оказала огромное влияние на систему спецпоселений. Для одних депортированных - трудпоселенцев («бывших кулаков») и спецпереселенцев (польских граждан) - война и первые послевоенные годы ознаменовались освобождением из-под надзора органов НКВД, для других - «наказанных народов» (немцев, чеченцев, ингушей, калмыков, крымских татар и др.) - массовым выселением с мест постоянного проживания.

28 августа 1941 г. в составе центрального аппарата НКВД СССР был образован Отдел спецпоселений ${ }^{102}$, созданный исключительно для приема и размещения перемещаемых немцев ${ }^{103}$. В этот же день вышел Указ Президиума Верховного Совета СССР «О переселении немцев, проживающих в районах Поволжья», который положил начало цепи депортаций граждан немецкой нацио-

96 До 15 февраля 1942 г. были освобождены еще несколько человек.

97 Занимал этот пост с февраля 1941 г.

98 Архив УФСБ России по ВО. Ф. 1пх. Оп. 5. Д. 1. Л. 42-42 об. Согласно этому сообщению, кроме спецпереселенцев, еще 100 польских граждан были освобождены из тюрем Вологодской области и 39 - из колоний.

${ }^{99}$ Архив УМВД России по ВО. Ф. 6. Оп. 1. Д. 416. Л. 103.

100 Земсков В.Н. Спецпоселенцы в СССР. 1930-1960. М.: Наука, 2005. С. 98-99. Со ссылкой на: ГАРФ. Ф. 9479. Оп. 1. Д. 89. Л. 189-191.

101 Всего в 35 субъектах и лагерях НКВД СССР содержалось 936547 чел., из них мужчин - 272 473, женщин - 285 197, подростков от 14 до 16 лет - 73 280, детей до 14 лет - 305597.

102 Архив УМВД России по ВО. Ф. 6. Оп. 1. Д. 415. Л. 95.

103 Отдел действовал параллельно с Отделом трудовых и специальных поселений ГУЛАГа НКВД СССР, был упразднен 14 ноября 1942 г., его функции переданы Отделу трудовых и специальных поселений ГУЛАГа НКВД СССР (См.: ГУЛАГ: Главное управление лагерей... M., 2000. C. 31, 270-271). 
нальности. Немцев в СССР депортировали практически отовсюду, откуда это было возможно по обстоятельствам войны. К началу 1942 г. на спецпоселении числилось 1 031,3 тыс. немцев, из них 800 тыс. составляли те, кого депортировали из европейской части СССР, а 231,3 тыс. - «местные» немцы (те, кого депортации подвергать не стали: переведя в спецконтингент, их оставляли на месте).

Следует отметить, что в данный период депортированные немцы на спецпоселение в Вологодскую область не поступали и с ее территории в другие регионы СССР не переселялись, а абсолютное большинство из проживающих немцев являлись трудпоселенцами («бывшими кулаками») ${ }^{104}$.

В соответствии с приказом НКВД СССР от 16 марта 1942 г. № 00530 «С объявлением штатов отделений-инспекций и поселковых комендатур и спецпоселений», в УНКВД по Вологодской области функции по надзору за спецпоселенцами стало осуществлять Отделение трудовых и спецпоселений 105 со штатом в 3 человека: начальник отделения, старший инспектор и инспектор. В подчинении указанного отделения находились Тотемская (штат - 6 человек: райкомендант, 4 поселковых коменданта и делопроизводитель-статистик) и Вожегодская (штат - 5 человек: райкомендант, 3 поселковых коменданта и делопроизводитель-статистик) районные комендатуры и Тарногская, Сямженская, Чебсарская, Бабушкинская, Нюксенская и Харовская поселковые комендатуры, в штат которых входили лишь поселковые коменданты ${ }^{106}$.

В местах нового расселения немцев особую остроту приобрел вопрос их трудового использования. Одним из способов его решения стала трудовая мобилизация немцев и формирование на время войны так называемой трудовой армии, «бойцы» которой призывались (мобилизовались) через военкоматы Народного Комиссариата Обороны и направлялись для трудового использования в районы, как правило, удаленные от мест, где на спецпоселении пребывали их семьи $^{107}$.

${ }^{104}$ В сентябре 1941 г. был подготовлен проект постановления ГКО СССР о переселении в период с 20 сентября по 10 октября 1941 г. в Казахскую ССР немцев общей численностью в 302288 чел. из 41 региона СССР, в том числе 696 чел. из Вологодской области. Однако данный проект был отвергнут. Вместо этого была издана серия постановлений, охватывающих каждым лишь ограниченный набор регионов. Вологодская область в их число не попала (См.: Сталинские депортации. 1928-1953 / под общ. ред. А.Н. Яковлева; сост. Н.Л. Поболь, П.М. Полян. М.: МФД: Материк, 2005. С. 334-337).

105 Фактически в Вологодской области продолжали существовать только трудпоселки для «бывших кулаков».

${ }^{106}$ Архив УМВД России по ВО. Ф. 6. Оп. 1. Д. 433. Л. 45.

107 Фактически трудовая армия начала формироваться с сентября 1941 г., когда строительные батальоны НКВД были реорганизованы в рабочие колонны с казарменным проживанием и лагерным распорядком. Одними из первых мобилизованных в нее немцев стали отозванные из действующей армии немцы-красноармейцы. Начиная с сентября 1941 г., их 
Специальные постановления Государственного комитета обороны СССР о мобилизации выселенного немецкого населения в трудовую армию от 10 января, 14 февраля и 7 октября 1942 г. и 26 апреля, 2 и 19 августа 1943 г. означали практически сплошную «мобилизацию» трудоспособного немецкого населения в трудармию ${ }^{108}$. При этом если в первых двух постановлениях речь шла только о мужчинах от 17 до 50 лет, то в третьем - уже о мужчинах от 15 до 55 лет, а также о женщинах от 16 до 45 лет, кроме беременных и имеющих малолетних (до 3-х лет) детей. За неявку по мобилизации, отказ от работы или саботаж карали сурово, вплоть до расстрела ${ }^{109}$.

С самого начала по ведомственной принадлежности военизированные рабочие колонны и отряды из мобилизованных немцев разделились на два типа. Первые - создавались и размещались при лагерях и стройках ГУЛАГа НКВД СССР, подчинялись лагерному начальству, охранялись и обеспечивались по нормам, установленным для заключенных. Вторые - образовывались при гражданских наркоматах и ведомствах, подчинялись их руководству, но контролировались органами НКВД. Административный режим этих формирований был менее строгим, чем колонн и отрядов, функционировавших внутри самого НКВ ${ }^{110}$. Как показывают архивные документы, немцы, мобилизованные на территории Вологодской области, направлялись в колонны, относящиеся к первому типу, а колонны из мобилизованных немцев, находившихся в Вологодской области, относились ко второму.

Так, в феврале-марте 1942 г., в соответствии с распоряжением заместителя Наркома внутренних дел СССР С.Н. Круглова была проведена мобилизация 278 немцев, постоянно проживающих на территории Вологодской области ${ }^{111}$. Все мобилизованные немцы были направлены для трудового использования в Северный железнодорожный ИТЛ ${ }^{12}$ НКВД СССР.

зачисляли в спецпоселенцы, но не демобилизовали, а направляли в трудовую армию, сочетавшую в себе элементы военных формирований, трудовой деятельности и гулаговского режима содержания. К началу 1942 г. трудармия фактически насчитывала 20,8 тыс. немцев. См. подробнее: Сталинские депортации... М., 2005. С. 374.

108 Официального употребления термин «трудармия» не имел, призыв осуществлялся в «рабочие колонны НКВД».

${ }^{109}$ Полян П.М. Не по своей воле... М., 2001. С. 114.

${ }^{110}$ Курочкин А.Н. Трудармейские формирования из граждан СССР немецкой национальности в годы Великой Отечественной войны (1941-1945 гг.): автореф. дис. ... канд. ист. наук. Саратовское ракетное училище, 1998. С. 66.

${ }^{111}$ Архив УФСБ России по ВО. Ф. 1пх. Оп. 5. Д. 15. Л. 28-28об.

112 Северный железнодорожный ИТЛ (Севжелдорлаг) был организован 10 мая 1938 г., закрыт 24 июля 1950 г. (объединен с Северо-Печорским ИТЛ с образованием Печорского ИТЛ), дислокация - пос. Княж-Погост Усть-Вымского района Коми АССР. Лагерь осуществлял строительство железной дороги Котлас-Воркута, в частности участков Котлас-УстьКожва (728 км), Коноша--Котлас, Вельск-Котлас-Кожва и др. Рабочие колонны немцев на 
Согласно постановлению Государственного комитета обороны от 7 октября 1942 г. № 2383сс на заготовку леса для треста «Нефтетара» в Вологодскую область планировалось направить 300 немцев ${ }^{113}$. Мобилизованные немцы прибыли на предприятия Вологодской области зимой 1943 года: 150 чел. - из Архангельской области (100 чел. - в Междуреченский МЛП (ст. Вохтога), 50 чел. - на Сокольский лесопильный завод); 103 чел. - из Ивановской области (53 немца в Междуреченский МЛП (ст. Вохтога), 50 немок - на Сокольский завод «Нефтетара») $)^{114}$.

В соответствии с приказом НКВД СССР от 21 июня 1943 г. № 01021 на ГУЛАГ НКВД СССР возлагался контроль за организацией режима и трудового использования, а также учет мобилизованных немцев, работающих на предприятиях наркоматов ${ }^{115}$.

По данным Управления исправительно-трудовых лагерей и колоний УНКВД по Вологодской области на 1 января 1944 года в Вологодской области находилось 238 мобилизованных немцев (мужчин - 34, женщин - 204) ${ }^{116}$. К 1 сентября 1945 г. в Вологодской области их число увеличилось до 329 чел., причем подавляющее большинство из них составляли женщины (см. табл. 1).

Как таковая трудармия была ликвидирована только в январе-марте 1946 г. ${ }^{117}$. Освободившиеся при этом трудармейцы (мобилизованные немцы) остались прикрепленными к тем же самым предприятиям, где они до этого работали, но получили право выписывать к себе семьи.

Численность трудпоселенцев за годы Великой Отечественной войны сократилась, прежде всего, вследствие их мобилизации в Красную Армию. Уже в первые военные месяцы в ряде краев и областей военкоматы частично призвали трудпоселенцев в строительные батальоны и кадровые части. Всего было призвано 3761 чел., в том числе по Вологодской области - 391 чел. $^{118}$

01.07.1942 г. состояли из 4954 чел., на 01.11.1942 г. - 5411 чел., на 01.01.1947 г. - 1130 чел. бывших трудмобилизованных немцев, переведенных на спецпоселение. См.: Система исправительно-трудовых лагерей в СССР. 1923-1960: справочник / сост. М.Б. Смирнов. М.: Звенья, 1998. С. 380-381.

${ }^{113}$ Бугай Н.Ф. Мобилизовать немцев в рабочие колонны... М., 1998. С. 80. Со ссылкой: ГАРФ. Ф. 9479. Оп. 1. Д. 111. Л. 43.

${ }^{114}$ Бугай Н.Ф. Мобилизовать немцев в рабочие колонны... М., 1998. С. 212-213, 215. Со ссылкой: ГАРФ. Ф. 9479. Оп. 1. Д. 111. Л. 47, 85.

115 Архив УМВД России по ВО. Ф. 24. Оп. 1. Д. 1. Л. 10.

116 Архив УМВД России по ВО. Ф. 24. Оп. 1. Д. 17. Л. 46.

117 Архив УМВД России по ВО. Ф. 24. Оп. 1. Д. 2. Л. 13.

118 Земсков В.Н. Спецпоселенцы в СССР... М., 2005. С. 102. Со ссылкой на: ГАРФ. Ф. 9479. Оп. 1. Д. 113. Л. 4-5. 


\section{Дислокация мобилизованных в промышленность немцев по состоянию на 1 сентября 1945 года ${ }^{119}$}

\begin{tabular}{|c|c|c|c|c|c|}
\hline \multirow{2}{*}{$\begin{array}{c}\text { Наименование } \\
\text { района и его } \\
\text { административ- } \\
\text { ного центра }\end{array}$} & \multirow{2}{*}{$\begin{array}{c}\text { Наименование } \\
\text { пункта расселения } \\
\text { (расстояние } \\
\text { до райцентра, км) }\end{array}$} & \multicolumn{3}{|c|}{ Количество } & \multirow{2}{*}{$\begin{array}{c}\text { Выполняемые } \\
\text { работы }\end{array}$} \\
\hline & & всего & мужчин & женщин & \\
\hline \multirow[t]{2}{*}{$\begin{array}{c}\text { Сокольский, } \\
\text { г. Сокол }\end{array}$} & $\begin{array}{c}\text { завод «Нефтетара» } \\
\text { (0 км) } \\
\text { завод «Имени } \\
\text { Свердлова» (0 км) }\end{array}$ & $\begin{array}{l}52 \\
78\end{array}$ & 1 & $\begin{array}{l}51 \\
78\end{array}$ & $\begin{array}{l}\text { заготовка клепки } \\
\text { заготовка древе- } \\
\text { сины }\end{array}$ \\
\hline & Итого & 130 & 1 & 129 & \\
\hline $\begin{array}{c}\text { Лежский, } \\
\text { с. Сидорово }\end{array}$ & $\begin{array}{c}\text { Завод «Нефтетара» } \\
\text { Междуреченского } \\
\text { МЛП (60 км) }\end{array}$ & 91 & 23 & 68 & заготовка клепки \\
\hline $\begin{array}{c}\text { Вытегорский, } \\
\text { г. Вытегра }\end{array}$ & $\begin{array}{c}\text { п. Белоручейский } \\
\text { (23 км) }\end{array}$ & 108 & - & 108 & $\begin{array}{l}\text { горно- } \\
\text { топографические } \\
\text { работы }\end{array}$ \\
\hline \multicolumn{2}{|c|}{ Всего по области } & 329 & 24 & 305 & \\
\hline
\end{tabular}

11 апреля 1942 г. Государственный комитет обороны СССР принял постановление № 1575 cс, согласно которому в период с 15 апреля по 15 мая 1942 г. надлежало призвать в Красную Армию 35 тыс. чел. из числа переселенцев призывного возраста. Постановлением ГКО № 2100сс от 22 июля 1942 г. этот план был увеличен до 50 тыс. чел. К 1 ноября 1942 г. мобилизация трудпоселенцев в Красную Армию завершилась. Всего с начала войны в армию было призвано 60747 трудпоселенцев (из них 57324 - в 1942 г.), в том числе 679 человек из Вологодской области $(20,4$ \% от общего числа трудпоселенцев-мужчин призывного возраста, проживавших на территории области) ${ }^{120}$.

В соответствии с приказом НКВД СССР № 002303 от 22 октября 1942 г. все призванные трудпоселенцы и члены их семей подлежали снятию с учета, получали паспорта и освобождались от пятипроцентных отчислений от их заработной платы. По состоянию на 21 июня 1943 г. в Вологодской области было снято с учета 677 семей (2 648 чел.), из них 995 мужчин, 489 женщин, 1164 ребенка $^{121}$. Судя по докладным запискам и спецсообщениям Управления НКВД по Вологодской области, призыв бывших трудпоселенцев в действующую армию повсеместно проходил организованно. Явка на призывные пункты была свое-

${ }^{119}$ Архив УМВД России по ВО. Ф. 24. Оп. 1. Д. 17. Л. 129.

120 Земсков В.Н. Судьба «кулацкой ссылки» в 1940-1954 гг. // Население России в ХХ веке. М.: РОССПЭН, 2001. Т. 2. 1940-1959. С. 297-298; ГАРФ. Ф. 9479. Оп. 1. Д. 113. Л. 215.

${ }^{121}$ ГАРФ. Ф. 9479. Оп. 1. Д. 113. Л. 211. 
временной. Большинство призывников отнеслись к мобилизации положительно, расценивая ее как выражение доверия со стороны властей. При этом многие выказывали патриотические чувства и готовность биться с врагом.

Как и остальные защитники Родины, «бывшие кулаки» не щадили своей жизни в борьбе с врагом. Многие не вернулись с полей сражений, многие были отмечены за ратные подвиги орденами и медалями. Двое из бывших трудпоселенцев - Берестовенко Михаил Порфирьевич (призван из пос. Харовск Харовского района) и Красник Иван Яковлевич (призван из пос. Зимняк Нюксенского района) стали Героями Советского Союза ${ }^{122}$.

В 1943 г. на основании распоряжения НКВД СССР от 13 апреля 1943 г. № 52/в-761 были мобилизованы 240 «бывших кулаков» ${ }^{123}$, их направили в Вятский ИТЛ ${ }^{124}$ НКВД СССР (Кировская область) ${ }^{125}$. Осенью 1943 года еще 98 трудпоселенцев были вывезены в Архангельскую область для работ по отгрузке крепежного леса на Усть-Шоношский лесоперевалочный комбинат Главснаблеса при СНК СССР (ст. Усть-Шоноша Северо-Печорской железной дороги $)^{126}$.

В марте 1944 г. Отдел трудовых и специальных поселений был выведен из состава ГУЛАГа и переименован в Отдел спецпоселений (ОСП) НКВД СССР. В итоге, трудпоселенцы в ведомственных документах стали именоваться спецпоселенцами (спецпереселенцами) ${ }^{127}$. Функции ОСП НКВД СССР и его территориальных органов заключались в следующем: а) содействие трудовому и хозяйственно-бытовому устройству спецпоселенцев; б) оперативно-чекистское обслуживание спецпоселенцев; в) учет спецпоселенцев и административный надзор за ними в местах их расселения.

122 Вологжане - Герои Советского Союза / сост. П.К. Перепеченко, Г.И. Соколов. Вологда: Северо-Западное книжное издательство, 1970. С. 54-55, 176-178.

${ }^{123}$ В их состав вошли как немцы, так и представители других национальностей.

${ }^{124}$ Вятский ИТЛ (Вятлаг) был организован 5 февраля 1938 года. В настоящее время на месте лагеря действует одно из учреждений УФСИН России по Кировской области (дислокация - п. Лесное Кировской области). Вятлаг специализировался на лесозаготовках, деревообработке, строительстве и обслуживании лесовозных железнодорожных веток и др. Отряды из мобилизованных немцев были сформированы 12 января 1942 года. См. подробнее: Система исправительно-трудовых лагерей в СССР / сост. М.Б. Смирнов. М.: Звенья, 1998. С. 200201.

${ }^{125}$ К июлю 1945 г. в Вятлаге осталось 140 чел., остальные либо умерли, либо были возвращены в Вологодскую область. См. Архив УМВД России по ВО. Ф. 24. Оп. 1. Д. 17. Л. 110-110 об.

${ }^{126}$ На основании распоряжения НКВД СССР от 5 июня 1944 г. № 1/10401 переданы на учет в Отдел спецпоселений УНКВД по Архангельской области. См. Архив УМВД России по ВО. Ф. 24. Оп. 1. Д. 17. Л. 110; Бугай Н.Ф. «Мобилизовать немцев в рабочие колонны... М., 1998. С. 228-229.

${ }^{127}$ Архив УМВД России по ВО. Ф. 6. Оп. 1. Д. 454. Л. 195. 
Приказом НКВД СССР от 16 августа 1944 года № 0170 была введена в действие инструкция по учету спецпоселенцев ${ }^{128}$. Необходимо было установить численность семей и количество спецпоселенцев, обеспечить контроль за их движением в границах районов расселения, выявить трудоспособных и контролировать их трудоустройство. Учет должен был способствовать также своевременному выявлению побегов, удовлетворению запросов органов НКВД, НКГБ, контрразведки НКО и НКВМФ, СМЕРШ, партийных и советских органов.

Учету подлежали все контингенты спецпоселенцев и каждый человек в отдельности в спецкомендатурах, районных отделениях НКВД и в ОСП УНКВД по специальным карточкам: № 1 - семейная, для учета глав семей; № 2 - персональная, для учета каждого спецпоселенца, за исключением глав семей и детей до 16 лет; № 3 - суммарная, для учета детей, не достигших 16-летнего возраста. Карточки (стандартный размер 95х140 мм) заполнялись на основании паспортов (при этом старые паспорта изымались и в городах выдавались новые, с отметкой о разрешении проживания в пределах данного района), свидетельств о браке, рождении, эшелонных списков, актов приема спецпоселенцев, постановлений или приговоров судебных органов, других официальных документов. В случае их отсутствия - путем опроса спецпоселенцев, с пометкой «заполнено со слов». Карточки заполнялись в двух экземплярах: один для картотеки районных отделений НКВД, второй - для справочной картотеки ОСП УНКВД ВО. На основе карточек в ОСП создавалась единая алфавитная картотека.

Семейная карточка содержала на первом и последнем листах сведения о главе семьи, а внутри - о ее членах. Указывались данные о времени и месте рождения спецпоселенца, его отношении к главе семьи, национальности и специальности, роде занятий до переселения, дате прибытия на место поселения, делалась отметка о трудоспособности.

В результате проведенного учета было установлено, что на 1 октября 1944 г. на спецпоселении в Вологодской области находилось 4858 «бывших кулаков», 362 немца, 1357 чеченцев и ингушей ${ }^{129}$.

Спецпоселенцы с Северного Кавказа прибыли в Вологодскую область осенью 1944 года из Казахской ССР, где были мобилизованы местными райвоенкоматами для работы на лесозаготовках. По прибытии в Вологодскую область они были сразу же направлены для трудового использования в трест «Череповецлес» Наркомлеспрома СССР и Монзенский леспромхо ${ }^{130}$.

${ }^{128}$ Архив УМВД России по ВО. Ф. 6. Оп. 1. Д. 455. Л. 288-295.

${ }^{129}$ Кокурин А.И. Спецпереселенцы в СССР в 1944 году, или Год большого переселения // Отечественные архивы. 1993. № 5. С. 109-110. Со ссылкой: ГАРФ. Ф. 9401. Оп. 2. Д. 86. Л. 64-65 об.

${ }^{130}$ Архив УМВД России по ВО. Ф. 8. Оп. 1. Д. 55. Л. 10. 
Еще летом для их размещения и оперативного обслуживания приказом начальника УНКВД по Вологодской области от 20 июля 1944 года № $0063^{131}$ были созданы 4 временных комендатуры: Белоручейская (Вытегорский район, пос. Белый Ручей), Коневская (Шольский район, пос. Конево), Ковжинская (Ковжинский район, пос. Анненский мост) и Вохтогская (Лежский район, ст. Вохтога). Кроме сотрудников НКВД Вологодской области обслуживание данных комендатур производилось воинскими группами из числа красноармейцев войск НКВД. На 1 квартал 1945 г. их численность составляла 12 человек: Белоручейская - 4 чел. (спецпоселенцев - 475 чел.), Ковжинская - 2 чел. (спецпоселенцев - 289 чел.), Коневская - 3 чел. (спецпоселенцев - 189 чел.) и Монзенская - 3 чел. (спецпоселенцев - 170 чел.) ${ }^{132}$.

Спецпоселенцы абсолютно не были готовы для работы на лесозаготовках, они не имели ни теплой одежды и обуви, ни опыта работы в лесу. Леспромхозы все необходимое также предоставить не могли. Вследствие этого установленные нормы выработки выходцы с Северного Кавказа не выполняли и получали весьма скудное питание. Данные факторы, а также суровые климатические условия, пагубно отразились на физическом состоянии спецпоселенцев и привели к массовым простудным заболеваниям, дистрофии и большой смертности (см. табл. 2).

Таблийа 2

Динамика смертности спецпоселенцев с Северного Кавказа ${ }^{133}$

\begin{tabular}{|c|c|c|c|}
\hline Квартал & $\begin{array}{c}\text { Количество на на- } \\
\text { чало квартала }\end{array}$ & Количество умерших & $\begin{array}{c}\text { В \% к общему } \\
\text { количеству }\end{array}$ \\
\hline 4 квартал 1944 года & 1358 чел. & 186 чел. & 13,7 \\
\hline 1 квартал 1945 года & 1123 чел. & 331 чел & 29,4 \\
\hline 2 квартал 1945 года & 774 чел. & 92 чел. & 11,8 \\
\hline Всего за весь период & 1358 чел. & 609 чел. & 44,8 \\
\hline
\end{tabular}

К началу 1945 г. из общего числа спецпоселенцев (1 123 чел.), трудоспособными являлись 556 чел. (49,5\%), из них работали только 186 чел. (18\%) ${ }^{134}$. По состоянию на 25 января 1945 г. большая часть спецпоселенцев (705 чел.) была крайне истощена и болела тяжелой степенью дистрофии. Только в марте 1945 г. произошло некоторое улучшение материально-бытовых условий спецпоселенцев. В частности, в два раза были увеличены нормы снабжения основными видами продуктов (мясом и крупой), налажена бесперебойная доставка жиров и

\footnotetext{
${ }^{131}$ Архив УМВД России по ВО. Ф. 7. Оп. 1. Д. 11. Л. 86-87.

${ }^{132}$ Архив УМВД России по ВО. Ф. 24. Оп. 1. Д. 17. Л. 22.

${ }^{133}$ Архив УМВД России по ВО. Ф. 8. Оп. 1. Д. 55. Л. 10; Д. 56. Л. 23-24.

${ }^{134}$ Архив УМВД России по ВО. Ф. 8. Оп. 1. Д. 54. Л. 25-26.
} 
сахара. К 1 апреля случаи заболевания дистрофией прекратились, однако смертность продолжала оставаться высокой (за 1 квартал умерло 92 чел.), имелось 284 больных ${ }^{135}$.

Массовый характер приобрели побеги из мест поселения, хищения продуктов, овощей и скота у местного населения. С момента прибытия до 1 апреля 1945 г. совершили побег 34 спецпоселенца, из низ 33 чел. были задержаны (30 чел. привлечены к уголовной ответственности) ${ }^{136}$.

Данная ситуация не устраивала ни руководство областного УНКВД, ни Отдел спецпоселений НКВД СССР. Вопрос о неудовлетворительном состоянии спецпоселенцев с Северного Кавказа неоднократно ставился перед дирекцией леспромхозов, областными органами исполнительной власти и партийными органами, однако никакой реакции не последовало. В конечном итоге, НКВД $\mathrm{CCCP,} \mathrm{в} \mathrm{лице} \mathrm{Отдела} \mathrm{спецпоселений,} \mathrm{принял} \mathrm{решение} \mathrm{о} \mathrm{возвращении} \mathrm{остав-}$ шихся к тому времени в живых 678 спецпоселенцев обратно в Казахскую ССР.

Первоначально погрузку и отправку эшелона планировалось осуществить 8 апреля 1945 г. Однако доставка спецпоселенцев из Вытегорского, Шольского и Ковжинского районов на ст. Череповец из-за весенней распутицы и значительного расстояния (около 300 км) оказалась невозможной. Отправка была отложена до начала навигации ${ }^{137}$. Лишь 30 мая 1945 г. эшелон со спецпоселенцами с Северного Кавказа (641 чел.) был направлен из Вологды в Алма-Ату. В Вологодской области остались лишь лица, отбывающее наказание в местах лишения свободы, и госпитализированные больные $\left(37\right.$ чел.) ${ }^{138}$. По освобождении и выздоровлении они также направлялись в Казахстан, одиночным порядком.

Постановлением СНК СССР № 34-14с от 8 января 1945 г. было утверждено «Положение о спецкомендатурах НКВД» ${ }^{139}$. Целями создания спецкомендатур являлись: обеспечение государственной безопасности, охраны общественного порядка и предотвращения побегов спецпереселенцев с мест их поселения; контроль за хозяйственно-трудовым устройством спецпереселенцев. Спецкомендатуры должны были создаваться в районах расселения спецпереселенцев и дислоцироваться в центре территории, на которой были расселены депортированные. Непосредственное руководство деятельностью спецкомендатур осуществляли районные отделы НКВД по территориальной принадлежности.

На комендантов спецкомендатур возлагались следующие обязанности: учет спецпереселенцев и надзор за ними, в целях предотвращения побегов с мест

${ }^{135}$ Архив УМВД России по ВО. Ф. 24. Оп. 1. Д. 17. Л. 47.

${ }^{136}$ Архив УМВД России по ВО. Ф. 24. Оп. 1. Д. 17. Л. 31.

${ }^{137}$ Архив УМВД России по ВО. Ф. 24. Оп. 1. Д. 17. Л. 41-42.

${ }^{138}$ Архив УМВД России по ВО. Ф. 24. Оп. 1. Д. 17. Л. 98.

${ }^{139}$ Сталинские депортации... М., 2005. С. 561-562. 
поселения и выявления среди них антисоветских и уголовно-преступных элементов; организация и производство розыска бежавших спецпереселенцев; предупреждение и пресечение беспорядков в местах поселения; осуществление контроля за хозяйственным и трудовым устройством спецпереселенцев в местах их расселения; прием от спецпереселенцев жалоб, заявлений и обеспечение по ним необходимых мероприятий; выдача спецпереселенцам разрешений на право временного выезда за пределы района расселения, обслуживаемого данной спецкомендатурой, без права выезда из района.

Комендантам предоставлялось право наложения административных взысканий (штраф до 100 рублей или арест до 5 суток) на спецпереселенцев, нарушивших режим и общественный порядок. Кроме того, комендантам вменялись в обязанность расследования по делам о побегах и других преступлениях спецпереселенцев.

Правовой статус спецпоселенцев (спецпереселенцев) был окончательно определен Постановлением СНК СССР от 8 января 1945 г. № 35. За ними признавались все права граждан СССР, за исключением ограничений, предусмотренных указанным постановлением. Они не могли без разрешения коменданта спецкомендатуры НКВД отлучаться за пределы района расселения. Самовольная отлучка за пределы района расселения рассматривалась как побег и влекла за собой ответственность в уголовном порядке. Главы семей (или лица их заменяющие) были обязаны в трехдневный срок сообщать в спецкомендатуру НКВД обо всех изменениях в составе семьи (рождение ребенка, смерть члена семьи, побег и т.д.). Спецпоселенцы должны были строго соблюдать установленный для них режим и общественный порядок в местах поселения и подчиняться всем распоряжениям спецкомендатур НКВД ${ }^{140}$.

В 1945 г. численность спецпоселенцев (спецпереселенцев) в Вологодской области значительно изменилась. Как указывалось выше, на основании распоряжений НКВД СССР все чеченцы и ингуши были возвращены на спецпоселение в Казахскую ССР. В апреле и июле 1945 г. на спецпоселение в Вологодскую область прибыли члены семей «оуновцев» (участников украинских националистических организаций ОУН и УПА) ${ }^{141}$. С октября 1945 г. стали поступать эшелоны с советскими немцами, вывезенными в годы Великой Отечественной войны в Австрию, Германию, Польшу и Чехословакию. В соответствии с директивой НКВД СССР № 181 от 11 октября 1945 г., все репатриированные

\footnotetext{
${ }^{140}$ Сталинские депортации... М., 2005. С. 563.
}

141 Самих участников организации в данном контингенте не было. Среди прибывших, в основном, были женщины и дети. Так, 23 апреля 1945 г. на спецпоселение в Череповецкий район Вологодской области прибыло 155 семей «оуновцев» в количестве 379 чел., в том числе 91 мужчина, 163 женщины, 125 детей до 16 лет. См. Архив УМВД России по ВО. Ф. 24. Оп. 1. Д. 17. Л. 48-49. 
советские граждане немецкой национальности подлежали направлению на спецпоселение под надзор органов НКВД ${ }^{142}$ (см. табл. 3).

Таблица 3

Прибытие спецпоселенцев в Вологодскую область в 1945-1946 гг. ${ }^{143}$

\begin{tabular}{|c|c|c|c|c|c|}
\hline $\begin{array}{c}\text { Номер } \\
\text { эшелона }\end{array}$ & $\begin{array}{c}\text { Дата и } \\
\text { станция } \\
\text { убытия } \\
\text { (область } \\
\text { выселения) }\end{array}$ & $\begin{array}{c}\text { Дата и } \\
\text { станция } \\
\text { прибытия }\end{array}$ & Контингент & $\begin{array}{c}\text { Количество } \\
\text { (человек) }\end{array}$ & $\begin{array}{c}\text { Предприятия } \\
\text { (районы), } \\
\text { в которые } \\
\text { направлены для } \\
\text { размещения и } \\
\text { трудоустройства } \\
\end{array}$ \\
\hline 1 & 2 & 3 & 4 & 5 & 6 \\
\hline 47467 & $\begin{array}{c}- \\
\text { Львовская }\end{array}$ & $\begin{array}{l}\text { 23.04.1945 г. } \\
\text { ст. Черепо- } \\
\text { вец }\end{array}$ & «оуновцы» & 379 & $\begin{array}{c}\text { совхоз «Комсомо- } \\
\text { лец» (Череповец- } \\
\text { кий район) }\end{array}$ \\
\hline- & $\begin{array}{c}- \\
\text { Львовская }\end{array}$ & $\begin{array}{c}24.07 .1945 \text { г. } \\
\text { ст. Котлас }\end{array}$ & «оуновцы» & 434 & $\begin{array}{c}\text { Удимский ЛПХ } \\
\text { треста «Устюглес» } \\
\text { (Великоустюгский } \\
\text { район) } \\
\end{array}$ \\
\hline 96582 & $\begin{array}{c}26.09 .1945 \text { г. } \\
\text { г. Брест }\end{array}$ & $\begin{array}{c}08.10 .1945 \text { г. } \\
\text { ст. Вологда }\end{array}$ & немцы & 2107 & $\begin{array}{c}\text { ЛПХ треста «Воло- } \\
\text { гдобумлес» (То- } \\
\text { темский, Бабуш- } \\
\text { кинский, } \\
\text { Биряковский, Ме- } \\
\text { ждуреченский рай- } \\
\text { оны) }\end{array}$ \\
\hline 97153 & $\begin{array}{c}07.10 .1945 \text { г. } \\
\text { г. Брест }\end{array}$ & $\begin{array}{c}20.10 . \\
1945 \text { г. } \\
\text { ст. Вологда }\end{array}$ & немцы & 2174 & $\begin{array}{c}\text { ЛПХ треста «Воло- } \\
\text { гдобумлес» (Ха- } \\
\text { ровский, Вожегод- } \\
\text { ский районы) }\end{array}$ \\
\hline 97156 & $\begin{array}{c}10.10 .1945 \text { г. } \\
\text { г. Брест }\end{array}$ & $\begin{array}{l}21.10 .1945 \text { г. } \\
\text { ст. Черепо- } \\
\text { вец }\end{array}$ & немцы & 2233 & $\begin{array}{c}\text { Шекснинский ЛПХ } \\
\text { Шекснинское па- } \\
\text { роходство Сухо- } \\
\text { нское пароходство } \\
\text { Наркомречфлота }\end{array}$ \\
\hline 97146 & $\begin{array}{c}15.10 .1945 \text { г. } \\
\text { г. Гродно }\end{array}$ & $\begin{array}{c}24.10 . \\
1945 \text { г. } \\
\text { ст. Котлас }\end{array}$ & немцы & 2167 & $\begin{array}{c}\text { Удимский ЛПХ } \\
\text { треста «Устюглес» } \\
\text { (Великоустюгский } \\
\text { район) } \\
\end{array}$ \\
\hline
\end{tabular}

142 Архив УМВД России по ВО. Ф. 24. Оп. 1. Д. 2. Л. 72-74.

${ }^{143}$ Архив УМВД России по ВО. Ф. 24. Оп. 1. Д. 17. Л. 48-49, 116, 133-134, 138, 140, $144-$ 147, 150, 157-158, 161-162; Д. 4. Л. 51, 56. 
Продолжение табл. 3

\begin{tabular}{|c|c|c|c|c|c|}
\hline 1 & 2 & 3 & 4 & 5 & 6 \\
\hline $\begin{array}{c}97 \\
153^{144}\end{array}$ & $\begin{array}{c}07.10 .1945 \text { г. } \\
\text { г. Брест }\end{array}$ & $\begin{array}{c}03.11 .1945 \text { г. } \\
\text { ст. Вологда }\end{array}$ & немцы & 138 & $\begin{array}{l}\text { ЛПХ треста «Вологдо- } \\
\text { бумлес» (Харовский, } \\
\text { Вожегодский районы) }\end{array}$ \\
\hline $\begin{array}{l}97149 / \\
97147\end{array}$ & $\begin{array}{l}29.10 .1945 \text { г. } \\
\text { г. Волковыск }\end{array}$ & $\begin{array}{l}05.11 .1945 \text { г. } \\
\text { ст. Черепо- } \\
\text { вец }\end{array}$ & немцы & 1859 & $\begin{array}{c}\text { Белоручейский ЛПХ } \\
\text { треста «Череповецлес» } \\
\text { (Вытегорский район) }\end{array}$ \\
\hline 97132 & $\begin{array}{c}26.10 .1945 \text { г. } \\
\text { г. Брест }\end{array}$ & $\begin{array}{c}11.11 .1945 \text { г. } \\
\text { ст. Вохтога }\end{array}$ & немцы & 2343 & $\begin{array}{c}\text { Монзенский ЛПХ Нар- } \\
\text { комлеса СССР (Лежский } \\
\text { район) }\end{array}$ \\
\hline 51579 & - & $\begin{array}{c}15.11 .1945 \text { г. } \\
\text { ст. Вологда }\end{array}$ & немцы & 1411 & Вологодский район \\
\hline 50209 & $\begin{array}{c}- \\
\text { г. Гродно }\end{array}$ & $\begin{array}{c}28.03 .1946 \text { г. } \\
\text { ст. Котлас }\end{array}$ & немцы & 1316 & $\begin{array}{c}\text { Красавинский текстиль- } \\
\text { ный комбинат (Велико- } \\
\text { устюгский район) }\end{array}$ \\
\hline 97079 & $\begin{array}{c}- \\
\text { Ровенская }\end{array}$ & $\begin{array}{c}28.03 .1946 \text { г. } \\
\text { ст. Котлас }\end{array}$ & «оуновцы» & 533 & $\begin{array}{c}\text { Красавинский текстиль- } \\
\text { ный комбинат (Велико- } \\
\text { устюгский район) }\end{array}$ \\
\hline
\end{tabular}

В связи с прибытием «оуновцев» и репатриированных немцев организуются новые спецкомендатуры в Великоустюгском, Бабаевском, Биряковском, Вытегорском, Кадуйском, Кирилловском, Лежском, Междуреченском и Череповецком районах, а также дополнительные в Бабушкинском, Вожегодском, Тотемском и Харовском районах Вологодской области ${ }^{145}$. В марте 1946 г. для спецпоселенцев, склонных к побегам, в Сямженском районе был организован поселок $^{146}$ особого режима.

На 1 января 1946 г. в Вологодской области на спецпоселении находилось 19835 чел. (кулаков - 4 424, репатриированных немцев - 14 371, «оуновцев» 708, мобилизованных немцев - 332), большинство из которых составляли женщины и дети (см. табл. 4). Спецпоселенцы проживали в 171 населенном пункте, подконтрольном 29 спецкомендатурам НКВД ${ }^{147}$.

144 Три вагона эшелона № 97153, отцепленные в пути следования по техническим причинам.

145 Архив УМВД России по ВО. Ф. 7. Оп. 1. Д. 12. Л. 112, 304, 379-380, 398; Д. 13. Л. $28-$ 29, 46, 49, 149.

${ }^{146}$ Архив УМВД России по ВО. Ф. 7. Оп. 1. Д. 13. Л. 45.

147 Спецпоселенцы, проживавшие в Устюженском и Ковжинском районах, находились под контролем районных отделов НКВД, проживавшие в Вологодском районе - Отдела спецпоселений УНКВД по Вологодской области (Архив УМВД России по ВО. Ф. 24. Оп. 1. Д. 4. Л. 32-38). 
Численность спецпоселенцев в Вологодской области на 1 января 1946 года

\begin{tabular}{|c|c|c|c|c|c|}
\hline Категория учета & $\begin{array}{c}\text { Количество } \\
\text { семей }\end{array}$ & $\begin{array}{c}\text { Количество } \\
\text { человек }\end{array}$ & Мужчин & Женщин & Детей до 16 лет \\
\hline Кулаки & 2176 & 4424 & 1462 & 1826 & 1136 \\
\hline Немцы & 4108 & 14371 & 2246 & 5661 & 6464 \\
\hline $\begin{array}{c}\text { Мобилизованные } \\
\text { немцы }\end{array}$ & - & 332 & 24 & 308 & - \\
\hline «Оуновцы» & 283 & 708 & 149 & 304 & 255 \\
\hline Итого & 6567 & 19835 & 3881 & 8099 & 7855 \\
\hline
\end{tabular}

В июне 1947 года бывшие кулаки, кроме этнических немцев ${ }^{148}$, на основании приказов МВД СССР от 16 мая 1947 г. № $00519^{149}$ и УМВД по Вологодской области от 27 мая 1947 г. № 0047 и от 31 мая 1947 г. № $0050^{150}$, были освобождены из спецпоселений Вологодской области.

Постановлением Совета Министров СССР от 22 февраля 1948 г. $^{151}$ предусматривалось выселение в Сибирь и Казахскую ССР в общей сложности 82,5 тыс. чел. из числа депортированных, находившихся на спецпоселении в европейской части СССР, в том числе 10297 чел. из Вологодской области. Однако, секретарь Вологодского обкома ВКП(б) и председатель Вологодского облисполкома обратились с ходатайством об оставлении спецпереселенцев в Вологодской области. Данное обращение было поддержано министром внутренних дел СССР С.Н. Кругловым, и спецпереселенцы были оставлены на мес$\mathrm{Te}^{152}$.

На основании Указа Президиума Верховного Совета СССР от 26 ноября 1948 г. спецпоселенцам - репатриированным немцам, немцам, выселенным и мобилизованным в период Великой Отечественной войны, а также «оуновцам», - предписывалось оставаться на спецпоселении навечно, без права возврата на прежнее место жительства ${ }^{153}$.

По состоянию на 1 февраля 1949 г. в Вологодской области насчитывалось 23 спецкомендатуры: в Тотемском районе - 3 (Тотемская, Шахто-Печенгская и

148 На спецпоселении было оставлено 105 немцев - бывших кулаков. См. Сталинские депортации... М., 2005. С. 758-759.

${ }^{149}$ Архив УМВД России по ВО. Ф. 6. Оп. 1. Д. 493. Л. 766.

${ }^{150}$ Архив УМВД России по ВО. Ф. 7. Оп. 1. Д. 14. Л. 106, 110-111.

${ }^{151}$ Бугай Н.Ф. Л. Берия - И. Сталину: «Согласно Вашему указанию...». М.: АИРО-ХХ, 1995. С. 224. Со ссылкой на: ГАРФ. Ф. 9479. Оп. 1. Д. 371. Л. 4.

${ }^{152}$ Бугай Н.Ф. Иосиф Сталин - Лаврентию Берии: «Их надо депортировать...» М., 1992. C. $82-83$.

${ }^{153}$ Сборник законодательных и нормативных актов о репрессиях и реабилитации жертв политических репрессий / сост. Е.А. Зайцев. М.: Республика, 1993. С. 124. 
Чуриловская), в Бабушкинском - 1 (Обирковская), в Нюксенском - 1 («Зимняк»), в Великоустюгском - 4 (Северная, Приводинская, Красавинская и Тоземская), в Вожегодском - 2 (Енальская и Пигомская), в Харовском - 2 (Семигородненская и Митинская), в Междуреченском - 1 (пос. Шиченга), в Лежском 2 (Лежская и Восьевская), и по одной в Череповецком, Вытегорском, Биряковском, Бабаевском, Кирилловском, Ковжинском и Вологодском районах.

В марте 1949 г. в соответствии с приказом МВД СССР № 00165 от 19 февраля 1949 г. «Об организации персонального учета выселенцев, спецпереселенцев по новой системе» ${ }^{154}$, проводился переучет всех спецпоселенцев, проживающих в Вологодской области. Все спецпоселенцы, подвергшиеся переселению по национальному признаку, были отнесены к категории «выселенцев». С этого времени устанавливались следующие виды их учета: в спецкомендатурах - посемейный учет всех лиц, по специальным книгам, и персональный учет для бежавших с территории спецкомендатуры, временно убывших и временно прибывших. Кроме книг учета коменданты вели журналы регистрации явок выселенцев. В посемейные книги не вносились члены семей выселенцев, сами выселенцами не бывшие, но вступившие с ними в брак (данные о них вносились в отдельный список); выселенки, вышедшие замуж за невыселенцев, с учета не снимались. В книге обязательно делалась отметка об убытии, в том числе детей, выехавших на учебу. Последние после окончания школы могли быть направлены на работу лишь в регионы, являвшиеся местом спецпоселения данного контингента, с обязательной постановкой на учет.

Городским и районным отделениям МВД поручался персональный карточный учет по форме № 5 (краткая). Здесь же хранились агентурно-розыскные дела на выселенцев, бежавших с территории района. На всех взрослых выселенцев, начиная с 16 лет, заводились учетные (личные) дела, в основание которых, кроме уже имевшихся данных, были положены составленные в ходе переучета анкеты.

В отделах УМВД по Вологодской области сосредоточивался весь посемейный и персональный (по форме № 6 - подробная) учет выселенцев, а в 1-м спецотделе МВД СССР - картотека специализированного персонального учета. Сюда высылались алфавитные и учетные карточки на вновь прибывших на спецпоселение, выбывших в другие места, освободившихся, умерших, подвергшихся аресту, бежавших, переведенных в дома инвалидов. В результате было установлено, что на спецпоселении проживает 9364 человека взрослых и детей, из них немцев - 8818 человек, украинцев-«оуновцев»-546 человек.

${ }^{154}$ Архив УМВД России по ВО. Ф. 6. Оп. 1. Д. 529. Л. 85-104. 
Численность и состав спецпоселенцев в Вологодской области в 1941-1950 гг. (на 1 января каждого года) ${ }^{155}$

\begin{tabular}{|c|c|c|c|}
\hline Год & Категории & Количество человек & Всего \\
\hline 1941 & $\begin{array}{c}\text { Трудпоселенцы } \\
\text { Спецпереселенцы }\end{array}$ & $\begin{array}{c}9978 \\
13139 \text { (9270 осадников } \\
\text { и } 3869 \text { беженцев) }\end{array}$ & 23117 \\
\hline 1942 & Трудпоселенцы & - & - \\
\hline 1943 & Трудпоселенцы & 5835 & 5835 \\
\hline 1944 & Трудпоселенцы & 5051 & 5051 \\
\hline 1945 & $\begin{array}{c}\text { C/п - бывшие кулаки } \\
\text { С/п - Северный Кавказ } \\
\text { «Мобилизованные немцы» }\end{array}$ & $\begin{array}{r}4699 \\
1123 \\
354^{156}\end{array}$ & 6176 \\
\hline 1946 & $\begin{array}{c}\text { С/п - бывшие кулаки } \\
\text { «Мобилизованные немцы» } \\
\text { Репатриированные немцы } \\
\text { «оуновцы» } \\
\end{array}$ & $\begin{array}{c}4424 \\
332 \\
14371 \\
708 \\
\end{array}$ & 19835 \\
\hline 1947 & $\begin{array}{c}\text { C/п - бывшие кулаки } \\
\text { Немцы } \\
\text { (мобилизованные и } \\
\text { репатриированные) } \\
\text { «оуновцы» }\end{array}$ & $\begin{array}{c}3954 \\
15132 \\
(14932+200) \\
1184\end{array}$ & 20270 \\
\hline 1948 & $\begin{array}{c}\text { Немцы } \\
\text { «оуновцы» }\end{array}$ & $\begin{array}{c}12016 \\
988 \\
\end{array}$ & 13004 \\
\hline 1949 & $\begin{array}{c}\text { Немцы } \\
\text { «оуновцы» }\end{array}$ & $\begin{array}{c}9520 \\
843 \\
\end{array}$ & 10363 \\
\hline 1950 & $\begin{array}{c}\text { Немцы (репатриированные, } \\
\text { мобилизованные, кулаки, } \\
\text { местные) } \\
\text { «оуновцы» } \\
\text { «власовцы» }\end{array}$ & $\begin{array}{c}9339 \\
(9069+141+116+13) \\
824 \\
2\end{array}$ & 10165 \\
\hline
\end{tabular}

${ }^{155}$ Архив УФСБ России по ВО. Ф. 1пх. Оп. 4. Д. 7. Л. 6 об; ГАРФ. Ф. 9479. Оп. 1. Д. 62. Л. 69; Д. 75. Л. 5; Д. 88. Л. 95; Земсков В.Н. Спецпоселенцы в СССР... М., 2005. С. 106; Архив УМВД России по ВО. Ф. 8. Оп. 1. Д. 54. Л. 28-30; Д. 57. Л. 19; Д. 62. Л. 6; Д. 66. Л. 13; Ф. 24. Оп. 1. Д. 4. Л. 8; Д. 5. Л. 39; Д. 6. Л. 26; Д. 7. Л. 7; Д. 9. Л. 139, 142, 145.

${ }^{156}$ Н.Ф. Бугай в предисловии к сборнику документов, посвященному истории принудительных мобилизаций немецкого населения в годы Великой Отечественной войны («Мобилизовать немцев в рабочие колонны... И. Сталин». С. 11) указывает, что на лесоразработках Вологодской области трудились 6665 мобилизованных в рабочие колонны и батальоны немцев. Фактически же в годы войны их максимальное число (на 1945 г.) составляло 354 чел., а в последующие годы только уменьшалось. Возможно, автор включил в число мобилизованных немцев немцев-репатриантов, направленных для трудового использования в лесозаготовительные организации области. 
В 1950 году спецпоселенцы - «оуновцы» по распоряжению МВД СССР были переселены в Иркутскую область. В Вологодской области остались только больные, инвалиды и вступившие в брак с местными жителями ${ }^{157}$.

Решением Совета Министров СССР от 14 июля 1950 г. № 3077-1286сс Отдел спецпоселений (ОСП) МВД СССР и его структурные подразделения на местах были переданы в ведение МГБ СССР (9-е Управление), на которое возлагалось руководство работой по спецпоселенцам ${ }^{158}$. После объединения МВД и МГБ приказом МВД СССР от 25 апреля 1953 г. № 00153 вместо 9-го Управления МГБ СССР в составе МВД СССР был создан отдел «П», на который возлагались: организация учета и регистрации ссыльных и высланных спецпоселенцев и ссыльно-поселенцев; обеспечение режима и чекистского надзора, проверка первичных материалов, получаемых от агентуры о вражеской деятельности спецконтингентов; предотвращение побегов и розыск бежавших ${ }^{159}$.

В соответствии с постановлением Совета Министров СССР от 13 августа 1954 г. и приказом МВД СССР № 00713 от 20 августа 1954 г. спецпоселенцынемцы - бывшие кулаки и мобилизованные в промышленность - были сняты с учета спецпоселения ${ }^{160}$. В результате данных мероприятий число спецкомендатур сократилось до 20, а количество спецпоселенцев уменьшилось до 5711 человек ${ }^{161}$.

30 октября 1954 г. отдел «П» был переименован в 4-й спецотдел МВД СССР. Аналогичные преобразования проводятся на местах. Отделения спецотдела осуществляли руководство и контроль за организацией режима и надзора в местах поселений, рассматривали дела, жалобы и заявления о снятии с учета спецпоселений, вели статистический учет и отчетность, оперативносправочные картотеки, осуществляли контроль за законностью содержания в местах поселений и за исполнением решений об освобождении из спецпоселений, производили выдачу нарядов для направления на спецпоселение и в ссылку, рассматривали дела на инвалидов, из числа особо опасных государственных

157 В апреле-мае 1950 г. в Иркутскую область было направлено 265 семей «оуновцев» (572 чел., из них 117 мужчин, 309 женщин, 146 детей до 16 лет). На 1 января 1952 г. на учете спецпоселения состояло 168 «оуновцев» (51 мужчина, 117 женщин). При этом непосредственно проживали на спецпоселении 6 чел., находились в инвалидных домах -20 чел., числился в бегах 1 чел., содержалось в местах лишения свободы - 141 чел. См. Архив УМВД России по ВО. Ф. 24. Оп. 1. Д. 9. Л. 142-143; Д. 10. Л. 226.

${ }^{158}$ Архив УМВД России по ВО. Ф. 6. Оп. 1. Д. 548. Л. 267-270.

159 Лубянка. ВЧК-ОГПУ-НКВД-НКГБ-МГБ-МВД-КГБ. 1917-1960 / под ред. Р.Г. Пихоя, сост. А.И. Кокурин, Н.В. Петров: справочник. М.: МФД, 1997. С. 73.

${ }^{160}$ Всего был снят с персонального учета 191 спецпоселенец (бывших кулаков - 67 чел., мобилизованных - 114 чел., местных - 9 чел.), также с посемейного учета были сняты дети спецпоселенцев в количестве 3264 чел. (Архив УМВД России по ВО. Ф. 24. Оп. 1. Д. 15. Л. 70, 79).

${ }^{161}$ Архив УМВД России по ВО. Ф. 24. Оп. 1. Д. 20. Л. 22-31. 
преступников, о передаче их под опеку родственников или помещения в дома инвалидов $^{162}$.

Оставшиеся на спецпоселении немцы, репатриированные из Германии и выселенные в годы Великой Отечественной войны, в количестве 5644 человек (взрослых) были сняты с учета спецпоселения и освобождены из-под административного надзора органов внутренних дел в январе-феврале 1956 года, на основании Указа Президиума Верховного Совета СССР от 13 декабря 1955 г. и приказа МВД СССР № 0601 от 16 декабря 1955 года ${ }^{163}$. В связи с этим, имевшиеся на тот момент в Вологодской области 20 спецкомендатур в феврале 1956 года были ликвидированы, а 4-й спецотдел УМВД по Вологодской области расформирован.

\section{Заключение}

В период «хрущевской» оттепели власть осудила культ личности И.В. Сталина и приоткрыла истинные масштабы политических репрессий. Начался постепенный процесс реабилитации лиц, пострадавших от государственного произвола в годы сталинизма. В середине 1950-х гг. снимается клеймо «врага народа» с сотен тысяч граждан нашей страны, осужденных по надуманным обвинениям. Тем не менее, массовые депортации населения по классовым, социальным, национальным, религиозным и иным признакам продолжали рассматриваться официальными властями как историческая закономерность, обусловленная историческим развитием советского государства.

Только с принятием Закона Российской Федерации от 18 октября 1991 г. № 1761-1 «О реабилитации жертв политических репрессий» насильственное выселение в административном порядке на спецпоселение под надзор органов ОГПУ-НКВД-МГБ-МВД СССР сотен тысяч крестьян и представителей «наказанных народов», а также членов их семей, было признано политической репрессией. УМВД России по Вологодской области за 1992-2017 гг. рассмотрено 24877 заявлений граждан о реабилитации, по результатам проверки которых было выдано 10899 справок о реабилитации граждан из числа репрессированных в административном порядке, а также членов их семей (см. табл. 6).

162 Смыкалин А.С. Колонии и тюрьмы в Советской России. М.: Юстиция, 2016. С. 195.

163 Начальник УМВД по Вологодской области полковник Н.Ф. Шеваров доложил 18 февраля 1956 г. в 4-е Спецотделы МВД СССР и МВД РСФСР, что УМВД по Вологодской области сняты с учета спецпоселения и освобождены из-под надзора органов МВД: репатриированные немцы - 5425 чел.; немцы, выселенные на спецпоселение в годы Великой Отечественной войны - 92 чел.; репатриированные немцы, отбывающие сроки наказания за контрреволюционные и другие преступления - 127 чел. Кроме немцев, были освобождены 7 «оуновцев», проживавших в домах инвалидов. См. Архив УМВД России по ВО. Ф. 24. Оп. 1. Д. 16. Л. 29-30. 
Таблииа 6

Деятельность УМВД России по Вологодской области по реабилитации жертв политических репрессий (1992-2017 гг.) ${ }^{164}$

\begin{tabular}{|c|c|c|c|c|}
\hline Год & $\begin{array}{c}\text { Количество } \\
\text { заявлений }\end{array}$ & $\begin{array}{c}\text { Реабилитировано } \\
\text { (чел.) }\end{array}$ & $\begin{array}{c}\text { Признано } \\
\text { пострадавшими } \\
\text { от политических } \\
\text { репрессий (чел.) }\end{array}$ & $\begin{array}{c}\text { Отказано в } \\
\text { реабилитации } \\
\text { (чел.) }\end{array}$ \\
\hline 1 & 2 & 3 & 4 & 5 \\
\hline 1992 & 892 & 535 & - & 66 \\
\hline 1993 & 1902 & 756 & 138 & 148 \\
\hline 1994 & 4516 & 1450 & 961 & 359 \\
\hline 1995 & 5999 & 1614 & 432 & 2140 \\
\hline 1996 & 3964 & 3043 & 14 & 697 \\
\hline 1997 & 1677 & 988 & 21 & 450 \\
\hline 1998 & 981 & 490 & 22 & 338 \\
\hline 1999 & 437 & 233 & 3 & 158 \\
\hline 2000 & 375 & 182 & 4 & 103 \\
\hline 2001 & 530 & 340 & - & 80 \\
\hline 2002 & 517 & 244 & - & 137 \\
\hline 2003 & 401 & 163 & - & 103 \\
\hline 2004 & 325 & 107 & - & 63 \\
\hline 2005 & 245 & 87 & - & 54 \\
\hline 2006 & 193 & 64 & - & 41 \\
\hline 2007 & 189 & 69 & - & 57 \\
\hline 2008 & 213 & 89 & - & 38 \\
\hline 2009 & 178 & 85 & - & 29 \\
\hline 2010 & 287 & 73 & - & 68 \\
\hline 2011 & 233 & 88 & - & 89 \\
\hline 2012 & 179 & 34 & - & 45 \\
\hline 2013 & 183 & 51 & - & 49 \\
\hline 2014 & 162 & 43 & - & 31 \\
\hline 2015 & 138 & 37 & - & 10 \\
\hline 2016 & 119 & 30 & - & 18 \\
\hline 2017 & 42 & 4 & - & 11 \\
\hline Итого & 24877 & 10899 & 1595 & 5382 \\
\hline
\end{tabular}

Таким образом, в начале $30-\mathrm{x}$ годов XX века с территории современной Вологодской области, в ходе насильственной коллективизации сельского хозяйства, были осуществлены массовые депортации крестьян в отдаленные районы страны (Коми АССР, Мурманская область, Сибирь, Дальний Восток). В то же

164 Текущий архив Информационного центра УМВД России по Вологодской области. Д. 50. Т. 2. Л. 120. 
время Вологодская область стала одним из регионов Советского Союза, где была сформирована сеть спецпоселений, в которых под надзором органов внутренних дел, в условиях ограничения прав и свобод, провели долгие годы своей жизни тысячи репрессированных советских и иностранных граждан и членов их семей. Дальнейшее изучение депортаций и судеб депортированных в Вологодской области позволит уточнить число жертв сталинского режима в нашем регионе и будет способствовать их реабилитации.

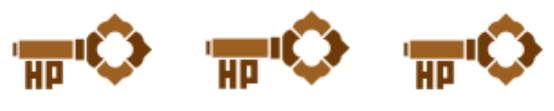

\section{Introduction}

Mass deportations of various groups of population to the remote areas of the USSR in the 1930s-1950s were an integral part of the repressive policy of the state.

The history of special settlements (special settlers) embraces more than three decades, of which for 14 years special settlements were a constituent part of the Main Administration of Camps and Places of Detention (GULAG) of the OGPU-NKVD of the USSR. Within the period of 1931-1959 special settlements were under the authority of the same department, the name and subordination of which changed several times: in 1931-1934 it was the Department of GULAG Special Resettlers of the OGPU of the USSR; in 1934-1940, the Department of GULAG Labor Settlements of the NKVD of the USSR; in 1940-1941, the Administration of GULAG Labor Settlements of the NKVD of the USSR; in 1940-1941, the Administration of GULAG Corrective Labor Colonies and Labor Settlements of the NKVD of the USSR; in 1941-1944, GULAG Department of Labor and Special Settlements of the NKVD of the USSR; in 1944-1950, the Department of Special Settlements of the NKVDMVD of the USSR; in 1950-1953, the Ninth Department of the MGB of the USSR; in 1953-1954, Department "P" of the MVD of the USSR; in 1954-1959, the Fourth Special Department of the MVD of the USSR (which was closed down in 1959; the persons in special settlements were transferred under the jurisdiction of the Main Directorate of Militsiya of the MVD of the USSR). ${ }^{1}$

The distinguishing feature of this kind of repression was that it was extrajudicial (administrative) and "on the rolls" (directed at a particular contingent). The repression was aimed not at a particular person but at a group of individuals, sometimes quite numerous, corresponding to the criteria sent down "from above"; as a rule, the

\footnotetext{
${ }^{1}$ Gosudarstvennyi arkhiv Rossiiskoi Federatsii (GARF) f. 9479. Historical note.
} 
decision was made by the leaders of the party and the government on the initiative of security bodies and other agencies.

For sending people to special settlements definite criteria (attributes) were necessary. They were different for different categories of special settlers and during different periods of deportations. The main attributes were the following: 1) class attribute (dispossessed kulaks, former nobility, Cossacks); 2) confessional attribute (clergy, true orthodox Christians, Jehovists, et al.); 3) political attribute (members of the forbidden parties, members of the families of the betrayers of the country, members of the families of the Organization of Ukrainian Nationalists - the Ukrainian Insurgent Army (OUN-UPA), Vlasovites); 4) ethnic attribute ("the punished peoples": Germans, Karachai, Kalmyks, Ingush, Chechens, Balkars, Crimean Tatars, et al.).

The legal status of special settlers was defined by the punitive agencies, mainly, on the basis of some formal characteristic, the latter being the document in compliance with which this or that category of citizens was brought to special settlement. The official statistics of the OGPU-NKVD-MVD-MGB used different terms for the groups of population under repression such as special resettlers, labor settlers, deportees, convict settlers, etc. However, basic "specific" rules (features) remained unchanged: 1) forced residence with the families in a certain locality which, as a rule, was an alien harsh environment difficult to survive in; 2) forced observing of all the rules connected with the legal position; 3) forced labor; 4) absence of the defined term of punishment.

A considerable number of scientific works and collections of documents on the history of special settlements have been published in the post-Soviet period. Russian and foreign authors and compilers have covered the history of developing and implementing anti-peasantry repressive policy in the course of forced collectivization in the USSR in the form of banishing and moving to special settlements (labor settlements) hundreds of thousands of peasant families as well as ethnic deportation campaigns and operations that took place in the $30 \mathrm{~s}-50 \mathrm{~s}$ of the $20^{\text {th }}$ century. ${ }^{2}$

${ }^{2}$ G.M. Adibekov, "Special settlers, the victims of 'wholesale collectivization'. From the documents in the 'special folder' of the Politburo of the Central Committee of VKP(b)", Istoricheskii arkhiv, no. 4 (1994): 145-80; L.P. Belkovets, Administrative and legal status of Russian Germans in special settlements, 1941-1955 (Moscow: ROSSPEN, 2008); V.A. Berdinskikh, Special settlers. Political exile of peoples of Soviet Russia (Kirov: Kirovskaya oblastnaya tipografiya, 2003); V.A. Berdinskikh, I.V. Berdinskikh, and V.I. Verem'ev, The system of special settlements in the Soviet Union in the 1930s-1950s (Moscow: ROSSPEN, 2017); N.F. Bugai, Joseph Stalin - Lavrenti Beria: "They are to be deported": documents, facts, commentary (Moscow: Druzhba narodov, 1992); N.F. Bugai, L. Beria - J. Stalin: "According to your Orders": On deportation of peoples in the USSR in 1930s-1940s (Moscow: AIRO-XX, 1995); N.F. Bugai, "Mobilize Germans into labor columns... J. Stalin”: collection of documents (Moscow: Gotika, 1998); N.F. Bugai, Deportations of Crimean peoples: documents, facts, commentary (Moscow: INSAN, 2002); N.F. Bugai and A.V. Gonov. Caucasus: peoples in special trains (1920s-1930s) (Moscow: INSAN, 1998); N.E. Vashkau, "Russian Germans in 'Labor Army': contribution to the Victory", in Feat of arms of 
the defenders of the Fartherland: tradition, continuity, innovation. Proceedings of the international scientific and practical conference. Part 3 (Vologda: Vologodskii institut razvitiya obrazovaniya, 2000), 200-07; N.E. Vashkau, "A woman in the Labor Army”, in Problems of the history of the Second World War: a collection of research papers (Vologda: Vologda State University, 2000), 8298; Lynne Viola, The Unknown Gulag. The Lost World of Stalin's Special Settlements (Moscow: ROSSPEN, 2010); L.I. Gintsberg, "Following the pages of the 'special folders' of the Pulitburo of the Central Committee of VKP(b)", Voprosy istorii, no. 8 (1996): 16-30; L.I. Gintsberg, "Mass deportations of peasants in 1930-1931 and the history of their existence in the Northern Regions (based on the materials in 'special folders' of the Politburo of the Central Committee of VKP(b) and the 'Andreev Commission”, Otechestvennaya istoriya, no. 2 (1998): 190-96; A.E. Gur'yanov, "Polish special settlers in the USSR in 1940-1941", in Repression against ethnic Poles and Polish citizens (Moscow: Zven'ya, 1997), 114-36; V.N. Zemskov, Special Settlers in the USSR, 19301960 (Moscow: Nauka, 2005); V.N. Zemskov, "Kulak exile in 1930s: numbers, settlement, composition", in Population of Russia in the $20^{\text {th }}$ century, ed. Yu.A. Polyakov, vol. 1 (Moscow: ROSSPEN, 2000), 277-310; V.N. Zemskov, "Deportation of population. Special settlers and exiles. Prisoners", in Population of Russia in the $20^{\text {th }}$ century, ed. Yu.A. Polyakov, vol. 2 (Moscow: ROSSPEN, 2000), 166-96; V.N. Zemskov "The fate of 'kulak exile' in 1940-1954", in Population of Russia in the 20 $0^{\text {th }}$ century, ed. Yu.A. Polyakov, vol. 2 (Moscow: ROSSPEN, 2001), 291-311; N.A. Ivnitskii, Collectivization and dekulakization. The early 1930s (Moscow: Interpraks, 1994); N.A. Ivnitskii, Repressive policy of Soviet rule in the countryside (Moscow: Institut rossiiskoi istorii RAN, 2000); N.A. Ivnitskii, The fate of dispossessed kulaks in the USSR (Moscow: Sobranie, 2004); S.A. Krasil'nikov, Sickle and moloch. Peasant exile in Western Siberia in 1930s (Moscow: ROSSPEN, 2003); S.A. Krasil'nikov, M.S. Salamatova, and S.N. Ushakova, Roots and chips. A peasant household in special settlement in Western Siberia in 1930s - early 1950s (M.: ROSSPEN, 2010); P. Polian, Against Their Will: The History and Geography of Forced Migrations in the USSR (Moscow: OGI-Memorial, 2001); A.B. Suslov, Special contingent in Perm Oblast (1929-1953) (Moscow: ROSSPEN, 2010); T. Chebykina, "Deportation of German population from the European USSR to Western Siberia", in Repression against Soviet Germans. A punished people (Moscow: Zven'ya, 1999), 118-27; A.A. Shevyakov, "The mysteries of the post-war repatriation", Sotsiologicheskie issledovaniya, no. 8 (1993): 3-12; A.A. Shevyakov, "Repatriation of Soviet civilian population and prisoners of war from the zones of occupation of Anti-Hitler Coalition states", in Population of Russia in 1920s-1950s: numbers, losses, migrations (Moscow: Institut rossiiskoi istorii RAN, 1994), 195-222; A.A. Shevyakov, "Hitler's genocide and repatriation of Soviet population", in Human losses of the USSR in the period of the Second World War (St Petersburg: Russko-Baltiiskii informatsionnyi tsentr "Blits", 1995), 178-81; T.V. Tsarevskaya, comp., History of Stalin's GULAG, vol. 5, Special settlers in the USSR (Moscow: ROSSPEN, 2004); N.N. Pokrovskii, ed., Politburo and peasantry: exile, special settlement. 1930-1940, vol. 1 (Moscow: ROSSPEN, 2005); N.N. Pokrovskii, V.P. Danilov, S.A. Krasil'nikov, and L. Viola, Politburo and peasantry: exile, special settlement. 1930-1940, vol. 2 (Moscow: ROSSPEN, 2006); A.N. Yakovleva, ed., Stalin's deportations. 1928-1953 (Moscow: MFD: Materik, 2005); D. Dahlmann, ""Operation erfolgreich durchgeführt". Die Deportationen der Wolgadeutschen 1941", in Flucht und Vertreibung: zwischen Aufrechnung und Verdraengung (Vienna: PicusVerlag, 1994), 201-26; A. Eisfeld and V. Herdt, Deportation, Sondersiedlung, Arbeitsarmee: Deutsche in der Sowjetunion 1941 bis 1956 (Köln: Wissenschaft und Politik, 1996); S. Merl, "Das System der Zwangsarbeit und die Opferzahl im Stalinismus", Geschichte im Wissenschaft und Unterricht, Jg. 46. Heft 5/6 (1995): 277-301; J.O. Pohl, The Stalinist Penal System. A Statistical History 
Historical literature of our region (the Republic of Karelia and Komi Republic, Arkhangelsk, Vologda and Murmansk Regions) was quick to cover the issues of both the history of political repression as a whole and subjecting the deported citizens of the USSR and other countries to limited rights and freedoms. It was our region that saw the publication of the first collections of archival documents which reflected the processes of "dekulakization", functioning of the GULAG, and using forced labor of special settlers on the regional scale. ${ }^{3}$

The research works exploring the history of special settlement and the regional collections of documents cover a wide range of problems under consideration. The works by L.I. Vavulinskaya, G.F. Dobronozhenko, N.M. Ignatova, O.A. Nikitina, M.B. Rogachev, L.S. Shabalova, V.Ya. Shashkov ${ }^{4}$ should be pointed out. They reveal

of Soviet Repression and Terror, 1930-1953 (Jefferson, NC: McFarland, 1997); T. Martin "The Origin of Soviet Ethnic Cleansing", The Journal of Modern History, vol. 70, no. 4 (1998): 812-61.

${ }^{3}$ L.I. Drazdovich, et al., eds., From the history of dekulakization in Karelia, 1930-1931: documents and materials (Petrozavodsk: Kareliya, 1991); A.Yu. Zhukov, ed., GULAG in Karelia: a collection of documents and materials (1930-1941) (Petrozavodsk: Karel'skii nauchnyi tsentr RAN, 1992); Timber industry of Komi ASSR: a collection of documents, 1917-1960 (Syktyvkar: Komi knizhnoe izdatel'stvo, 1989).

${ }^{4}$ L.I. Vavulinskaya, Special settlers and foreign prisoners of war in Karelia in the mid-1940s mid-1950s (Petrozavodsk: Karel'skii nauchnyi tsentr RAN, 2013); A.E. Gur'yanov, "Introduction", in Polish special settlers in Arkhangelsk Oblast. Part 1. Index of the victims of repression. Issue XIV (Warsaw: Tsentr Karta; Informatsionnyi tsentr UVD Arkhangel'skoi oblasti; Memorial, 2003), 754-810; G.F. Dobronozhenko, "Conducting wholesale collectivization in the Northern Krai (1929-1932)" (PhD diss., Pertozavodsk, 1993); G.F. Dobronozhenko, Collectivization in the North. 1929-1932 (Syktyvkar: Syktyvkar University, 1994); G.F. Dobronozhenko and L.S. Shabalova, "Kulak exile in Komi Oblast in the first half of 1930s", in Penance: martyrology, vol. 4, part 1 (Syktyvkar: Komi knizhnoe izdatel'stvo, 2001), 15-123; N.M. Ignatova, "Special settlers in Komi Republic in 1930s-1940s: settlement and living conditions", in Roots of the grass: a collection of papers by young historians (Moscow: Zven'ya, 1996), 23-35; N.M. Ignatova, "Periodization of the process of special resettlement", in Pressing issues of Komi Republic local studies (Syktyvkar: Obshchestvo izucheniya Komi kraya; Ministerstvo po delam natsional'nostei Respubliki Komi, 1997), 32-33; N.M. Ignatova, "Social protest of special settlers in the Northern Krai in 19301936", in Dvina land: proceedings of interregional Stephen of Perm readings in social sciences and local history (Kotlas: Pravda Severa, 2002), 81-89; N.M. Ignatova, "Social protest of special settlers in Arkhangelsk Oblast and Komi Republic in 1941-1945", in Defenders of the Fatherland: proceedings of the $15^{\text {th }}$ regional readings in social sciences on military history (Arkhangelsk: Pravda Severa, 2004), 148-56; N.M. Ignatova, Special settlers in Komi Republic in 1930s-1950s (Syktyvkar: Komi nauchnyi tsentr Instituta yazyka, literatury i istorii, 2009); N.M. Ignatova, "Mortality rate of special settlers in the Northern Krai in 1930s: causes, scale, statistical records", The New Historical Bulletin, no. 2 (28), (2011): 42-52; N.M. Ignatova, "Forced labor of special settlers as a systematic factor for industrial reclamation of the northern regions in 1930s-1950s", in History of Stalinism: Forced labor in the USSR. Economics, policies, memory: proceedings of the international scientific conference. Moscow, 28-29 October, 2011, eds. L.I. Borodkin, S.A. Krasil'nikov, and O.V. Khlevnyuk (Moscow: ROSSPEN, 2013), 433-49; N.M. Ignatova, "Conscripting labor settlers of the USSR to the front in 1942", Voprosy istorii, no. 11, (2013): 97-103; O.A. Nikitina, "Collec- 
the causes and stages of the deportations to the European North, reception and settling of special settlers, their economic status, social and domestic conditions, using their labor, the activities of OGPU-NKVD-MVD-MGB organs to establish and maintain the operation of special settlements in the territories of the present Republic of Karelia, Komi Republic, Arkhangelsk and Murmansk Regions.

V.B. Konasov and V.V. Sudakov ${ }^{5}$ who were the first to tackle the history of the deported USSR citizens staying in Vologda Region described the position of special settlers in Vologda Region during the years of the Great Patriotic War. In our opinion, however, this subject is still on the fringes of research and has been considered only in several publications, ${ }^{6}$ the history of Polish special settlers in Vologda Region having been studied in most detail. ${ }^{7}$

tivization and dekulakization in Karelia" (PhD thesis, Institute of Russian History of Russian Academy of Sciences, 1993); M.B. Rogachev, "Deportation of Polish citizens to Komi ASSR (19401941)", in Poles in Russia: history of exile and deportation: abstracts and materials (St. Petersburg, 1995), 31-46; M.B. Rogachev, "Pages of Polish tragedy: facts and documents", in Penance: martyrology, vol. 5 (Syktyvkar: Komi knizhnoe izdatel'stvo, 2002), 14-463; N.V. Upadyshev, GULAG in European North: genesis, evolution, decline (Arkhangelsk: Pomorskii universitet, 2007); V.Ya. Shashkov, Special settlers in Murman. The role of special settlers in the development of productive forces in the Kola Peninsula (Murmansk: Murmanskii gosudarstvennyi pedagogicheskii universitet, 1993); V.Ya. Shashkov, "Dekulakization in the USSR and the fate of special settlers (1930-1954)" (Doctorate diss., Lomonosov Moscow State University, 1995); V.Ya. Shashkov, Repression against peasants in the USSR and the fate of special settlers in Karelia and Murmansk regions (Murmansk: Murmanskii gosudarstvennyi pedagogicheskii universitet, 2000); V.Ya. Shashkov, S.S. Kozlov, and L.N. Lobchenko. The GULAG system of the Northern Krai special settlements for the "former kulaks" (Murmansk: Murmanskii gosudarstvennyi pedagogicheskii universitet, 2008); etc.

${ }^{5}$ V.B. Konasov and V.V. Sudakov, Echo of the past war: from the history of Vologda Oblast (Vologda: Institut povysheniya kvalifikatsii i professional'noi perepodgotovki kadrov, 1994), 5766.

${ }^{6}$ S.I. Starostin, "Tragic pages in history. The $i$ 's haven't been dotted yet", in Historical local studies and archives: proceedings of $5^{\text {th }}$ and $6^{\text {th }}$ scientific and practical conferences, is. 5 (Vologda: Poligrafist, 1999), 67-76; S.I. Starostin, "The history of Soviet exile in the European North: 19301956", in History and prospects of Russian penitentiary system: proceedings of the scientific and practical seminar (Vologda, 4 April 2002) (Vologda: Vologodskii institut prava i ekonomiki Minyusta Rossii, 2002), 98-106; S.I. Starostin, "Structure and functions of the administration of the special settlements in Vologda Ovlast in 1930-1956", in Historical local studies and archives: a collection of articles. Issue 9 (Vologda: Poligrafist, 2003), 109-25; S.I. Starostin, "Documents from the archive of Vologda Oblast Internal Affairs Administration about the fate of the deported citizens of the USSR and other countries", in Historical local studies and archives: proceedings of the interregional scientific conference. 20.03.2003. Issue 10 (Vologda: Poligrafist, 2004), 184-96; S.I. Starostin, "Deported Soviet and foreign citizens during the years of the Great Patriotic War (case study of Archangelsk Region and Vologda Region)", in 1941-1945: history Lessons are the Lessons of truth, courage and patriotism: proceedings of the international scientific conference (Vologda, 24-25 February 2005) (Vologda: Rus', 2006), 101-12; S.I. Starostin, "Resettling Poles from Vologda Region (1944)", in Historical local studies and archives: proceedings of the regional 
Based on the documents form the state archives and the archives of particular agencies of Vologda and Arkhangelsk Regions, this article will consider the issue of forcible deportations of population from the territory of the present Vologda Region and the presence of different groups of special settlers in its territory in 1930-1956 as well as the issue of the number and the geography of settling the citizens subjected to repression.

\section{Main body}

According to the data of N.A. Ivnitskii, not less than a million farms with the population of 5-6 million people underwent dekulakization (by means of administrative and repressive or economic measures) during collectivization in the USSR and only an insignificant part of them belonged to the exploitative stratum of the village. More than one third of the dekulakized peasants or 2 million 140 thousand persons were deported (forcibly transferred from their permanent place of residence to the remote districts of the USSR) in 1930-1933. ${ }^{8}$

The tragedy of mass collectivization did not spare Vologda Region, a part of which at the time was included into the Northern Krai (the center of which was the city of Arkhangelsk) and another part belonged to Leningrad Region.

The implementation of the policy "of the liquidation of the kulak as a class" began in the middle of the winter of 1930 after the adoption of CC VKP(b) decree of 30 January 1930 "On Measures for the Liquidation of Kulak Farms in Raions of Wholesale Collectivization", ${ }^{9}$ the decree of the Central Executive Committee (CEC)

scientific and practical conference. Issue 17 (Vologda: Poligrafist, 2010), 138-45; A.L. Kuzminykh and S.I. Starostin, "Polish prisoners of war and special settlers in Vologda Region (1939-1941)", in Russia - Poland: philological and historical and cultural discourse: collected papers of the participants of the international scientific conference (Magnitogorsk, 18-19 November 2005) (Magnitogorsk: Magnitogorskii gosudarstvennyi universitet, 2005), 104-11; Dzenkevich, A., E. Rybarska, A. Gur'yanov, A. Rachinskii, and S. Starostin (comps.), Polish special settlers in Vologda Oblast. Alphabetical list of 14226 Polish citizens deported from the western oblasts of the Belorussian SSR and Ukrainian SSR. Index of repression victims. Issue 17 (Warsaw: Tsentr KARTA; Informatsionnyi tsentr UVD Arkhangel'skoi oblasti; Memorial, 2005); O.V. Artemova, "Special settlers in Vozhega district (the 1930s)", in Vozhega: an almanac of regional studies (Vologda: Rus', 1995), 195-220; S.N. Tsvetkov, "On the attitudes of the USSR citizens of German ethnicity who returned from abroad to reside in Vologda Oblast after the Great Patriotic War", in Feat of arms of the defenders of the Fartherland: tradition, continuity, innovation. Proceedings of the interregional scientific and practical conference, part 3 (Vologda: Vologodskii institut razvitiya obrazovaniya, 2000), 200-07.

${ }^{7}$ A.L. Kuzminykh and S.I. Starostin, Poles in Vologda Oblast: repression, captivity, special settlement (1937-1953) (Vologda: Drevnosti Severa, 2014).

${ }^{8}$ N.A. Ivnitskii, Collectivization and dekulakization. The early 30s (Moscow: Interpraks, 1994), 257.

${ }^{9}$ G.F. Vesnovskaya (ed.), A collection of legislative and statutory acts on repression and rehabilitation of the victims of political repression, part 1 (Kursk: Kursk, 1999), 293-99. 
and the Council of People's Commissars (SNK) of the USSR of 1 February 1930 "On Measures for enforcing socialist reorganization of agriculture in raions of wholesale collectivization and for struggle against the kulak" ${ }^{\prime 10}$ and the issue of the order of the OGPU of the USSR No. 44/21 of 2 February $1930^{11}$ which determined the mechanism of applying repressive measures to those under dekulakization. The order stressed that to solve the task entrusted by the party to the OGPU organs the latter would need "exceptionally intense effort, determination, and perseverance, an exceptionally rigorous class line, and efficient and swift action". ${ }^{12}$

Initially, the Northern Kraikom of $\operatorname{VKP}(b)$ planned to dekulakize and exile about 6000 kulak farms in raions of wholesale collectivization (1 000 farms in Arkhangelsk Okrug, 2500 farms in Vologda Okrug, 1200 farms in Nyandoma Okrug, 800 farms in Northern Dvina Okrug, 500 farms in Komi Region). The remaining kulak farms were to have been transferred outside the borders of the raions to worse lands. In the other raions of the krai (those of non-wholesale collectivization) up to 3000 kulak households that "counteract the measures of the party and Soviet rule in the country, are engaged in counterrevolutionary agitation, do not fulfill their obligations to the state, are saboteurs, etc." 13 were to have been removed outside the borders of the okrugs. It was planned to resettle the kulaks from Vologda Okrug to Northern Dvina Okrug; from Northern Dvina Okrug, to Arkhangelsk Okrug; from Nyandoma and Arkhangelsk okrugs, to Komi Region; and to send the kulaks from Komi Region to its northern part. ${ }^{14}$ However, the draft plan was not approved.

On 5 February 1930 the bureau of the Northern Kraikom of VKP(b) adopted the decree on the liquidation of the kulak as a class in the Northern Krai. ${ }^{15}$ According to the decree the kulaks were subdivided into three categories. The first category included "the counterrevolutionary top of the kulaks"" (1 500 farms or $0.3 \%$ of the total number of peasant farms) which was to be liquidated in all raions of the krai by 20 February. By the decisions of the troika at the OGPU Plenipotentiary Representative Office (PP OGPU) of the Northern Krai, the kulaks were condemned to incarceration in concentration camps, and the most active of them were sentenced to death penalty.

${ }^{10}$ Collection of laws and regulations of the Workers' and Peasants' Government of the Union of Soviet Socialist Republics, no. 9, (Moscow: Upravlenie delami Soveta Narodnykh Komissarov Soyuza SSR i Soveta Truda i Oborony, 1930), st. 105.

${ }^{11}$ Tragedy of the Soviet village. 1927-1939. Vol. 2. November, 1929 - December, 1930 (Moscow: ROSSPEN, 2000), 163-167.

${ }^{12}$ Tragedy of the Soviet village, 163.

${ }^{13}$ Otdel dokumentov sotsial'no-politicheskoi istorii Gosudarstvennogo arkhiva Arkhangel'skoi oblasti (ODSPI GAAO) f. 290, op. 1, d. 378, 1. 40.

${ }^{14}$ ODSPI GAAO f. 290, op. 1, d. 378, 1. 41.

${ }^{15}$ ODSPI GAAO f. 290, op. 1, d. 378, 11. 35-39.

${ }^{16}$ ODSPI GAAO f. 290 , op. 1, d. 378, 1. 35. 
Their property was confiscated and their families were exiled from the permanent place of residence. ${ }^{17}$

The second category included kulak farms in the raions of wholesale collectivization. After confiscation of their property, they were subject to resettlement to the sparsely populated northern raions of the krai through PP OGPU. The number of such farms was determined by the Okrug Committee "on the basis of the actual number of kulak farms in each raion" 18 but was not to exceed 3-5\% of the total number of farms in a raion.

Kulak farms which were not included into the second category belonged to the third category and were subject to resettlement within the raion on new land plots allotted to them outside collective farm lands. It was planned to begin the expulsion of the kulaks of the second and third categories on 20 March. ${ }^{19}$ Besides, the decree of the bureau of the Northern Kraikom made provisions not only for forcible exile but also for "voluntary" resettlement of individual kulak farms to the northern raions of the krai allowing them to keep certain means and implements. ${ }^{20}$

On 5 February 1930 PP OGPU of the Northern Krai issued the order No. 131 "On Measures for the Liquidation of the Kulak as a Class in the territory of the Krai" according to which 1500 persons were subject to repression in the okrugs of the krai including 400 persons in Arkhangelsk Okrug, 200 persons in Nyandoma Okrug, 400 persons in Vologda Okrug, 300 persons in Northern Dvina Okrug, and 200 persons in Komi Region. ${ }^{21}$

According to the order of PP OGPU of the Northern Krai No. 24/7 of 7 February, an operational group was formed for the immediate command of the operation to dispossess and exile kulak households. ${ }^{22}$ However, on 27 February the decree of the Northern Kraikom of VKP(b) of 5 February was changed. Because of "the difficulties in resettlement and overloading the krai with resettlers" the commission of $\operatorname{VKP}(b)$ kraikom reduced the number of kulak farms subject to dekulakization under the second category to $1 \%$. The remaining kulak farms were attributed to the third category and were subject to relocation within the borders of the okrugs. ${ }^{23}$

${ }^{17}$ Households with no able-bodied members were moved to worse lands within the borders of the same raion. Households which included able-bodied members were moved to the scarcely populated wilderness of the northern raions of the krai.

${ }^{18}$ ODSPI GAAO f. 290, op. 1, d. 378, 1. 35.

${ }^{19}$ ODSPI GAAO f. 290, op. 1, d. 378, 1. 37.

${ }^{20}$ ODSPI GAAO f. 290, op. 1, d. 378, 1. 37. This provision is found in the decisions of the Northern Kraikom of VKP(b) only.

${ }^{21}$ V.T. Belov, O.I. Korytova, and V.S. Tsyvarev, eds., Pomor memorial. Book of memory of the victims of political repression, vol. 1 (Arkhangelsk: Pomorskii gosudarstvennyi universitet, 1999), 785-86.

${ }^{22}$ V.T. Belov, O.I. Korytova, and V.S. Tsyvarev, Pomor memorial, 788.

${ }^{23}$ ODSPI GAAO f. 290, op. 1, d. 20, 1. 33-36. 
Dekulakization and dispossession themselves were implemented with gross violations. In Vologda Okrug these measures were distinctly militarized. Thus, detachments of armed Red Army soldiers and Komsomol members (100 persons) were involved in dekulakization operations in Sverdlov raion. In the town of Kadnikov martial law was introduced (pickets were posted and houses were cordoned off). Everyone walking or travelling through the town was detained and arrested. On repeated occasions, the residents not engaged in agriculture (workers, teachers, pensioners from among the former office workers) were dekulakized. During dekulakization all their belongings (food, clothes, tableware, footwear, etc.) were taken away from them and dumped into storerooms without ant inventory being made while valuable things were appropriated by the officials of the raion committee, raion executive committee and militsiya.

Typical were the instances of using major violence against peasants and threatening them with weapons. In such a way, a foreman responsible for dekulakization and a militsiya officer feigned shooting of peasants in Gribtsovo Village Soviet; in Rabanga Village Soviet, while questioning the arrested peasants, a representative of the raion executive committee shot at the ceiling and threatened them with violence. Similar methods were used for dekulakization in other raions of the Okrug: Vologda Raion, Kubeno-Ozersky Raion, Kharovsk Raion, Syamzha Raion, Shuiskoe Raion, Totma Raion, Tolshmensky Raion, et al. ${ }^{24}$

The procedure of dekulakization in Leningrad Region was determined by the directive of the Leningrad Region Executive Committee of 24 March 1930 "On the procedure of Dekulakization and Liquidation of Excesses". ${ }^{25}$ The procedure of dekulakization ${ }^{26}$ was as follows: 1) the meetings of the village poor and collective farmers made preliminary decisions about dekulakization and exile; 2) each case of exile and confiscation of the property of a kulak farm was considered by a raion executive committee (approval of the decisions of the poor and collective farmers); 3 ) actual eviction and confiscation of the property of each particular kulak farm was performed only after it had been approved by the executive committee of the okrug.

For operational management of resettlement and relocation a Region commission was formed. It included the representatives from the planning department, land management department, administrative department, and the organizations concerned. Okrug executive committees were ordered to from similar commissions which were to be chaired by a member of the okrug executive committee presidium and to com-

${ }^{24}$ Gosudarstvennyi arkhiv Vologodskoi oblasti (GAVO) f. 407, op. 1, d. 98, 1. 122-123; f. 22, op. 2, d. 10, 11. 79-79 ob., 108-109.

${ }^{25}$ N.A. Ivnitskii ed., Collectivization of agriculture in the North-Western area (1927-1937): collection of documents (Leningrad, 1970), 170-71.

${ }^{26}$ It was similar to the procedure in the Northern Krai. 
prise representatives of land management department and administrative department of the okrug.

Resettling "counterrevolutionary and openly hostile part of the kulak" 27 outside the Region was conducted by the OGPU organs while resettling peasant farms considered as kulaks within the Region was the responsibility of the Soviet administrative bodies.

The measures taken by the OGPU organs followed two basic lines: 1) immediate liquidation of "the cadre of active counterrevolutionary and insurrectionist organizations and groups, and the most inveterate, diehard individuals" 28 (category 1); 2) mass exile from the raions of wholesale collectivization and the border zone of the richest kulaks and their families to remote northern areas of the USSR and confiscation of their property (category 2).

According to the decree of CC VKP(b) of 30 January 1930, the OGPU established the number of persons to be arrested by raions. Arrestees were to be concentrated in okrug and Region departments of the OGPU. Their cases were to be considered on an urgent basis by the troikas for the extrajudicial consideration of cases, comprising the representatives of the VKP(b) Region committee, the OGPU, and public prosecution office. The majority of the arrestees were incarcerated in concentration camps. Moreover, usually a kulak, arrested and convicted by the OGPU organs, had already been placed in the camp while the village soviet and the raion executive committee were still taking the decision on dekulakization and exile of that particular kulak. For instance, Gleb Ivanovich Kosov, born in 1867 in the village of Korotovo of Chetepovets Raion, who resided in the village of Teplovo of the Kadui Village Soviet, was sentences to 5 years of corrective labor camp under article 58-10 of the Criminal Code of the RSFSR on 18 March 1930 but the presidium of Kadui raion executive committee took the decision to exile him on 7 April 1930. ${ }^{29}$

The south-eastern part of Lodeinoe Pole Okrug and Leningrad Okrug (Andomsky, Kovzhinsky, Vytegra, Vinnitsy, Oyatsky, Pikalevo, Kapshino and Tikhvin raions) and the north-eastern part of Cherepovets Okrug (Belozersk, Sholsky, Vashkinsky, Petropavlovskoe and Kirillov raions) were intended for resettlement inside the Region. Those raions were sparsely populated and remote from the state border and main railways. It was planned that the exiled kulaks should be used both for agricultural work and for felling, trimming, and floating timber. ${ }^{30}$ However, no archival documents to testify to the implementation of those plans have been found as

${ }^{27}$ N.A. Ivnitskii, Collectivization of agriculture in the North-Western area, 170-71.

${ }^{28}$ Dobronozhenko, G.F., and L.S. Shabalova. "Kulak exile in Komi Oblast in the first half of 1930s", in Penance: martyrology, vol. 4, part 1, 138-42 (Syktyvkar: Komi knizhnoe izdatel'stvo, 2001).

${ }^{29}$ Arkhiv UMVD Rossii po Vologodskoi oblasti (Arkhiv UMVD Rossii po VO) f. 48. Rehabilitation case of G.I. Kosov.

${ }^{30}$ N.A. Ivnitskii, Collectivization of agriculture in the North-Western area, 407. 
yet. ${ }^{31}$ In 1930 the Northern Krai became one of the regions of destination for wholesale exile of the dekulalized peasants. The choice was not random and was accounted for by a number of reasons. In the context of predesigned rapid industrialization this region with its vast area, sparse population and rich natural resources was considered as a major supplier of currency necessary for industrial engineering. The kulaks deported from the other regions were to compensate the deficiency of labor force and provide a significant increase in logging and manufacture of export products. The availability of transportation network (railways and water ways) in the Northern Krai made it possible to transport the dispossessed kulaks to the locations of their permanent settlement and the size of the krai allowed settling large masses of people. ${ }^{32}$

On 31 January 1930 the meeting of the bureau of the Northern Krai Executive Committee approved the plan of settling the deported kulaks according to which 70 thousand households (350 thousand people) were to be accommodated. Of them, 30 thousand households was planned for Arkhangelsk Okrug; 10 thousand, for Vologda Okrug; 9.5 thousand, for North Dvina Okrug; 9.5 thousand, for Nyandoma Okrug; 12 thousand, for Komi Region. ${ }^{33}$

First special trains with dispossessed kulaks started to arrive in the Northern Krai at the end of February 1930. By 20 May 46562 families (230 065 people) had arrived, of which 19658 families (93 461 people) were from Ukraine; 8237 families (42 837 people), from the Central Black Earth Region; 7981 families (40 001 people), from the Low Volga Krai; 5566 families (29 211 people), from the Middle Volga Krai; 4763 families (22 810 people), from the Belorussian SSR; 407 families (1 745 people) from Crimea. ${ }^{34}$

Able-bodied men were immediately assigned to the construction of barracks and timber harvesting. Women, children and the elderly were housed in transit prisons,

${ }^{31}$ At the same time, judging by the archival documents, expulsion of some peasants (including those exiled under the sentences of the People's Court of Vytegra Raion) took place in Vytegra Raion (the village of Izvest of Kudamozero Village Soviet) and in Borisovo-Sudskoe Raion (the village of Kargozero of Nozhema Village Soviet and the village of Pustyn of Ploskovsky Village Soviet). However, these villages were not included into the system of labor settlements (special settlements) of the Leningrad Oblast OGPU-NKVD. In fact, they were logging depots of the local logging enterprises and the persons who resided there were not under the supervision of the OGPUNKVD organs. According to the order of the Leningrad Oblast NKVD Administration No. 49 of 7 August 1935, Kirovsk Raion commandant's office and the commandant's offices of the village of Murmanskaya and of the labor settlements "Nivastroi", "Karelgranit", "Diabaz" and "Sinyavinskikh Torforazrabotok" were placed under the authority of the Department of Camps, Places of Detention and Labor Settlements of the Leningrad Oblast NKVD Administration. See Arkhiv UMVD Rossii po VO f. 6, op. 1, d. 148, 11. 119-119 ob.

${ }^{32}$ N.V. Upadyshev, GULAG in the European North: genesis, evolution, decline (Arkhangelsk: Pomorskii gosudarstvennyi universitet, 2007), 69.

${ }^{33}$ ODSPI GAAO f. 290, op. 1, d. 378, 11. 11-12.

${ }^{34}$ ODSPI GAAO f. 290. op. 1. d. 98a. 1. 115; d. 384. 1. 15. 
former monasteries, churches and temporary barracks built along Vologda-VyatkaKotlas-Arkhangelsk railway lines. Vologda Okrug accommodated 53357 people; Northern Dvina Okrug, 54422 people; Arkhangelsk Okrug, 44808 people; Nyandoma Okrug, 13228 people. Vologda with its suburbs was the site of the largest concentration of the deported kulaks 42120 people. Large groups of special settlers were located in Kadnikov (5 331 people) and Veliky Ustyug (3 824 people). ${ }^{35}$ Their situation was terrible: there was a lack of normal housing and food supply while infectious diseases were rampant and deaths were massive.

In compliance with the resolution of the Northern Kraikom of $\operatorname{VKP}(b)$ of 1 April 1930 on settling and accommodating kulak migrants in the Northern Krai, the resettlement plan was based on agricultural colonization of uninhabited and sparsely populated areas. Initially, the Krai Commission at the Krai Executive Committee was formed to guide the work on settling and accommodating the exile kulak families and a special Resettlement Office was established as a body of Narkomzem [People's Commissariat for Agriculture] for conducting practical and operational work on resettlement. A commandant and a militsiya officer whose upkeep was funded out of the state budget were appointed to each settlement by the OGPU. ${ }^{36}$

On 3 April 1930 the issue "on the Plan of Settling the Kulaks" was brought up for discussion at the meeting of the Krai Executive Committee Presidium. To continue the work on settling former kulaks a committee consisting of three persons was formed. It included Komissarov (head of the Krai Executive Committee), Sheiron (deputy OGPU plenipotentiary representative) and Lyutikov (head of the NKVD department). ${ }^{37}$

Upon transferring to the Krai Executive Committee all further work connected with settling, accommodating, supplying, and using the kulaks, and land reclamation and cultivation by the kulaks, the OGPU organs, which had been conducting that work before, retained the function of general supervision and assistance, cheka services, and transportation of family members to the sites of their permanent settlement. For that purpose, in compliance with the Northern Krai OGPU PP order of 30 May 1930 No. 32/20 a troika which included officials of the secret, economic and information departments was formed at the Northern Krai PP OGPU Office. Similar troikas were formed at Okrug OGPU departments. "In view of the necessity to use summer season for dispatching kulak families to the sites of permanent settlement and accommodating them" these troikas were ordered "to pay exceptional attention to building residential structures, distribution and harvesting of timber, distribution and

${ }^{35}$ Gosudarstvennyi arkhiv Arkhangel'skoi oblasti (GAAO) f. 621, op. 2, d. 26, 1. 603.

${ }^{36}$ Collectivization of agriculture in the Northern area (1927-1937): a collection of documents (Vologda: Severo-Zapadnoe knizhnoe izdatel'stvo, 1964), 318-19.

${ }^{37}$ V.Ya. Shashkov, "Dekulakization in the USSR and the fate of special settlers (1930-1954)" (doctorate diss. Lomonosov Moscow State University, 1995), 153. 
transportation of the delivered building materials and tools to the construction sites, allotment of land, distribution of agricultural implements and seeds and dispatching them on the sites, purchase of horses and dairy cattle, food supplies, setting up firstaid posts, and so on." ${ }^{38}$ Thus, nearly all the activities conducted by the local executive bodies remained under the official control of the OGPU organs.

According to OGPU statistics, 46623 households (230 370 people) were exiled to the Northern Krai, of them 61 households (305 people) were resettled inside the krai. $^{39}$

A new stage of dekulakization and deportation of peasants started in the spring of 1931. It was the year when the process of forcibly transferring the able-bodied, most enterprising part of the peasantry reached its climax. The decree of the Central Executive Committee and SNK of the USSR of 1 February 1931 "On Granting Krai (Region) Executive Committees and the Governments of Union Republics the Right to Exile Kulaks from the Areas of Wholesale Collectivization of Agriculture" ${ }^{, 4}$ actually gave the green light to the new deportations of peasants that were even more extensive than those of 1930 .

The experience of population transfer (resettlement) of 1930 showed that, having made the decision on kulak farms of category 3, their expropriation and resettlement, the central party and soviet agencies supported it with neither material and technical nor organizational and logistical recourses. That is why the OGPU suggested that all dispossessed kulaks should be placed in special settlements and used predominantly in remote raions in need of labor force for timber harvesting, peat extraction, rock extraction, apatite mining, and railway construction. ${ }^{41}$

By that time OGPU had been handling immense material and financial resources at its own discretion and controlling allocation of funds assigned to economic administrative agencies for the needs of special resettlers. This punitive organ had turned into an economic monster with well-developed infrastructure which, among other things, included special settlements for the deported peasants. Moreover, the OGPU exerted great influence on the special commission headed by A.A. Andreev established by the CC Politburo on 11 March 1931 for the guidance of exile and resettlement of dispossessed kulaks. It included OGPU deputy chairman G.G. Yagoda. The commission dealt with all the issues connected with dekulakization, resettlement, and using dispossessed kulaks. After that its decisions were approved by the Politburo

${ }^{38}$ Arkhiv UMVD Rossii po Arkhangel'skoi oblasti (Arkhiv UMVD Rossii po AO) f. 4, op. 1, d. 2, 1. 41-43.

${ }^{39}$ N.N. Pokrovskii et al., eds., Politburo and peasantry: exile, special settlement. 1930-1940, bk. 2 (Moscow: ROSSPEN, 2006), 312.

${ }^{40}$ P. Polian, Against their will: the history and geography of forced migrations in the USSR (Moscow: OGI-Memorial, 2001), 70.

${ }^{41}$ N.A. Ivnitskii, Collectivization and dekulakization. The early 1930s ( Moscow: Interpraks, 1994), 137. 
and came into effect in the form of decrees, obligatory for all bodies of authority and party leaders. ${ }^{42}$

The new wave of deportation actually surged in the middle of March 1931. The eviction was conducted from 20 March till 25 April and from 10 May till 18 September with the traditional break for sowing. The scenario remained the same. First, the decision on exile was taken by the group of poor peasants under the village soviet, then it was repeated by the village soviet's presidium, and the final verdict of exile was issued at the session of the local troika. The whole procedure took from 3 to 5 days.

The analysis of archival documents shows that the peasants from Leningrad Region who were dekulakized in the spring of 1931 were sent to special settlements in Siberia and in the Far East (Aldan Raion of the Yakut ASSR, Amur, Irkutsk and Chita Regions and Khabarovsk Krai) where they were to work at gold mines. Many of them suffered a tragic fate: some died en route to special settlement and others died during the first months and years of being there of hunger, harsh weather conditions, terrible working conditions, epidemics and illness.

The peasants from Leningrad Region who were dekulakized in the late spring and early summer of 1931 were to have been sent for special settlement in Kazakhstan. However, on 30 May the "Andreev's Commission" made the decision to move 4000 kulak households to the northern raions of Leningrad Region. On 5 June 1931 the decision was approved by the corresponding decree of the Politburo of the Central Committee of VKP(b). ${ }^{43}$

The procedure of exile in June 1931 was no different from the previous ones. Nearly all the decisions on dekulakization taken by the general meetings of poor peasants and by the presidia of village soviets were approved by the raion executive committees on 23-24 June. The kulaks and their family members were expeditiously sent to the Kola Peninsula (the territory of Leningrad Region at the time) where they started working at the construction of the Niva River hydroelectric power plants (Kandalaksha Raion). ${ }^{44}$ Besides, some of them were sent to apatite and nickel mines and resided in the town of Khibinogorsk (now Kirovsk). ${ }^{45}$

${ }^{42}$ N.A. Ivnitskii, Collectivization and dekulakization. The early 1930s ( Moscow: Interpraks, 1994), 169.

${ }^{43}$ G.M. Adibekov, "Special settlers, the victims of 'wholesale collectivization'. From the documents in the 'special folder' of the Politburo of the Central Committee of VKP(b)", Istoricheskii arkhiv, no. 4 (1994): 157-59.

44 Arkhiv UMVD Rossii po VO f. 48. Rehabiliation cases of the families of Baskovy, Vorob'evy, Prozorovy, et al.

45 In September 1941 a group of the deportees (1 259 people) were evacuated to UstKamenogorsk in the Eastern Kazakh Region of the Kazakh SSR, see Arkhiv UMVD Rossii po VO f. 48, op. 1, d. 38, 1. 31; Gosudarstvennyi arkhiv Vostochno-Kazakhstanskoi oblasti f. 462, op. 4, d. $1,1.1-18$. 
In 1931 a large-scale operation to move dispossessed kulaks form the southern raions to the north was conducted in the Northern Krai as well. On 11 February 1931 the Bureau of the Northern Kraikom of VKP(b) adopted the decree on exiling 3000 kulak households (categories 1 and 2) from the main dairy cattle raising and flax growing raions as well as from the raions with the high percentage of collectivization. ${ }^{46}$ In April 1931 the Politburo of the CC VKP(b) agreed with the Northern Krai Executive Committee and authorized the operation to exile kulak households. In order to perform organizational work on dekulakization and eviction a special krai commission was established at the Northern Kraikom of VKP(b). The commission included the chair of the Northern Krai Executive Committee and representatives of the krai land management department, the krai prosecutor's office, the court and the OGPU.

In the middle of April the commission adopted the instruction on evicting counterrevolutionary kulak households of the Northern Krai which defined "the expropriation from the households being exiled", calendar dates and the locations for settling the kulaks in the remote raions of the krai. In total, it was planned to evict 2750 households (by raion, as follows: Yemets Raion, 26; Kargopol Raion, 53; Onega Raion, 35; Pavlin Vinogradov Raion, 71; Primorsky (Arkhangelsk) Raion, 64; Kholmogory Raion, 200; Shenkursk Raion, 68; Vologda Raion, 170; Vozhega Raion, 127; Verkhovazhye Raion, 25; Velsk Raion, 36; Gryazovets Raion, 186; Kokshengsky Raion, 41; Kubeno-Ozersky Raion, 125; Ledengskoye Raion, 54; Sverdlovsky Raion, 140; Syamzha Raion, 30; Tolshmensky Raion, 71; Totma Raion, 66; Ust-Kubensky Raion, 120; Kharovsk Raion, 120; Chyobsara Raion, 90; Shuiskoe Raion, 83; Veliky Ustyug Raion, 150; Vokhma Raion, 103; Kichmengsky Gorodok Raion, 130; Kotlas Raion, 144; Lalsk Raion, 37; Nikolsk Raion, 133; Oparino Raion, 26; Podosinovets Raion, 51; Roslyatino Raion, 20; Cherevkovo Raion, 40; Vilegodsky Raion, 24). Apparently, the remaining 250 households were those to be exiled from the southern raions of Komi Region. ${ }^{47}$

In the second half of April the plan of resettlement was amended. The kulaks from 5 northern raions of the Vologda operational sector and from 11 southern raions of the Kotlas operational sector were to be moved to Mezen, Leshukonskoye and Kargopol raions. The dispossessed kulaks from 13 southern raions of the Vologda operational sector were to be moved to Udora, Ust'-Tsyl'ma, Storozhevsk, and Ust'Kulom raions. The households of the other dispossessed kulaks were to be moved to the Pechora river area to Ust'-Tsyl'ma and Izhma raions. ${ }^{48}$

According to OGPU statistics, 11648 households (55239 people) were exiled to the Northern Krai, of them 3000 households (15000 people) were moved under the

\footnotetext{
${ }^{46}$ ODSPI GAAO f. 296, op. 1, d. 381, 1. 38-39.

${ }^{47}$ G.F. Dobronozhenko and L.S. Shabalova, Kulak exile in Komi Region, 47-48.

${ }^{48}$ G.F. Dobronozhenko and L.S. Shabalova, Kulak exile in Komi Region, 47-48.
} 
resettlement inside the krai. ${ }^{49}$ In fact, by the time of termination of resettling kulak households inside the krai (August 1931), of 3000 households to be exiled a little more than 1.3 thousand, i.e. twice as little, had been evicted. The OGPU Plenipotentiary Representative Office in the Northern Krai noted the impossibility of the fullscale exile due to the fact that about a thousand households had left their permanent residence and fled and more than a thousand households did not include any ablebodied members and so they were not subject to exile. ${ }^{50}$

The summer of 1931 saw significant changes in the functioning of the system of special settlements for deported peasants. Almost a year-long experience of using the exiled kulaks showed that economic administrative agencies proved to be incapable of organizing the work in such "specific" field of activity. That is why on the order of the OGPU No. 285/162 of 3 June 1931 all existent economic and administrative agencies and personnel (commandant's offices and special settlements) in raions kulaks were brought under the authority of the OGPU. Management and control of all operations was assigned to the GULAG which comprised a recently established Department of Special Resettlers. Similar departments were formed at the local OGPU plenipotentiary representatives' offices. ${ }^{51}$

Initially, in compliance with the order No. 161/60 of 8 June 1931 a group was formed at the Northern Krai OGPU plenipotentiary representative office to provide economic, administrative and organizational service to special settlers and exiles. The corresponding department was established under the order of the Northern Krai OGPU plenipotentiary representative No. 191/73 of 22 June $1931 .^{52}$

Each settlement was to accommodate about a hundred households. Administrative governance of a settlement was the responsibility of a specially appointed commandant. From 2 to 5 riflemen of the guard were assigned to assist him. Additional positions of raion inspector for special resettlers, assistant inspector and clerk were introduced in the OGPU raion departments. They provided regular supervision over

${ }^{49}$ N.N. Pokrovskii, Politburo and peasantry, 312.

${ }^{50}$ N.N. Pokrovskii, Politburo and peasantry, 1038.

${ }^{51}$ A.I. Kokurin and N.V. Petrov, "OGPU (1929-1934)", Svobodnaya mysl' - XXI, no. 8 (1998): 102.

52 Arkhiv UMVD Rossii po AO. f. 4, op. 1, d. 4, 11. 87, 92. According to the order of the USSR NKVD No. 0044 of 21 August 1934 "On Structural Arrangement and Subordination of the NKVD organs" the Department of Special Settlers of the former NKVD Plenipotentiary Representative Office in the Northern Krai was renamed "the Department of Labor Settlements of the NKVD Administration in the Northern Krai (since December 1936, the Northern Region), see A.I. Kokurin and N.V. Petrov, "GULAG: structure and personnel”, Svobodnaya mysl'- XXI, no. 8 (1999): 116. Until 1 September 1944 the upkeep of the whole personnel was funded by 5\% deduction from the salary of labor settlers employed by economic organizations (until August 1931, 25\% was deducted and until February 1932 the deduction amounted to 15\%), see Arkhiv UMVD Rossii po VO f. 24, op. 1, d. $1,1.49$. 
the use of special resettlers in general labor activities, "everyday and cheka service and proper registration".

On 25 October 1931 "Temporary Regulations on Rights and Duties of Special Resettlers and on Administrative Functions and Administrative Rights of Settlement Administration in Raions of Resettling Special Settlers" ${ }^{, 53}$ was approved. According to the regulations, in addition to their special operational and economic functions, the OGPU commandant's offices took charge of the administrative functions as well. Besides, they were granted ample rights. Commandant's offices drew up internal rules of conduct for a settlement depending on its size, economic tasks and characteristics; assigned certain houses to certain households (persons), kept accurate record of their names and conducted roll-calls; defined the sites and type of work to be done by special resettlers subordinate to the commandant's office; granted permission for using special resettlers for different kinds of economic activities; accepted applications, complaints and requests of special resettlers, considered them on-site and resolved them within the limits of their authority; bore responsibility for political and public order in special settlements. In the event of violation of the internal rules of conduct commandant's offices were entitled to impose administrative punishment on special resettlers, such as arrest, amercement, transfer to less comfortable and less paid work, or removal to other settlements.

By 1933 the number of special settlers had become appreciably greater than the number of those confined in the OGPU camps, which gave rise to the idea of substantial reorganization of the administration of detention facilities and special settlements of the OGPU system. It was proposed to establish an independent Main Administration of Special Labor Settlements of the OGPU. The order of the OGPU Administrative Office No. 48 of 27 February 1933 assigned temporary personnel (250 persons) to the administration but any further appointments did not follow. Eventually, the Department of Special Settlements as well as the local bodies was left within the structure of the GULAG (until 1934 the latter was included in the OGPU system and since 1934 it belonged to the NKVD system). ${ }^{54}$

Instead of this, on 17 April 1933 CC VKP(b) issued the decree of "On Organizing OGPU Labor Settlements" which was approved by the decree of the SNK of the USSR No. 775/146 of 20 April. These documents ordered, firstly, to entrust the OGPU with the organization of labor settlements upon the model of the existing special settlements for housing and economic use of the contingents being resettled; secondly, to reorganize the Main Administration of Camps of the OGPU into the Main Administration of Camps and Labor Settlements of the OGPU; thirdly, to use the labor of the contingents being exiled by means of organizing agricultural, fishing,

${ }^{53}$ V.P. Danilov and S.A. Krasil'nikov, eds., Special settlers in Western Siberia. 1933: a collection of documents (Novosibirsk: EKOR, 1993), 68-74.

${ }^{54}$ A.I. Kokurin and N.V. Petrov, "OGPU (1929-1934)", Svobodnaya mysl' - XXI, no. 8 (1998): 107. 
handicraft and other kinds of economic activities in the places of resettlement; fourthly, to entrust the OGPU with the organization of residential, utility and cultural, and sanitary and medical construction in labor settlements and with the provision of all kinds of supplies (food, manufactured goods, agricultural implements, tools, at al.); fifthly, to oblige people's commissariats and economic agencies servicing special settlements of the previous resettlement to transfer all the personnel engaged in servicing special settlers to the OGPU until May; sixthly, to equalize in all respects the contingent of those being resettled to the special settlers who were resettled in 19301931 , etc. ${ }^{55}$

In 1932-1933 dekulakization and exile of peasant households were conducted predominantly on case-by-case basis, that is by way of exception or while purging collective farms of kulak elements and saboteurs. In such a way 3260 kulaks were exiled to the Northern Krai during the first half of $1932^{56}$ and 16659 kulaks were exiled in $1933 .{ }^{57}$

In compliance with the Constitution of 1936 special settlers were granted civil rights but they were not allowed to leave the place of exile. ${ }^{58}$ The repression against peasants ("the former kulaks") did not stop after the adoption of the 1936 Constitution which proclaimed the victory of socialism in the USSR.

In 1937-1938 the wheel of the Great Terror swept through Vologda Region just like it swept through the whole country. As is known, the repression unfolded along two lines. The first was the so-called "Kulak Operation" and the second was the "ethnicity" operation (against Poles, Greeks, Bulgarians, Lithuanians, Romanians and others). Based on the decision of specially established extrajudicial organs (dvoikas, troikas, special troikas) sentences were passed, their contents being premeditated. ${ }^{59}$

While organizing and conducting "the kulak operation", all those to undergo repression were divided into two categories. The first category included "the most hostile elements" subject to immediate arrest and, on consideration of their cases by troikas, to execution by shooting. The second category included "less active elements".

55 A.I. Kokurin and N.V. Petrov, "GULAG: structure and personnel”, Svobodnaya mysl' - XXI, no. 8 (1999): 116.

${ }^{56}$ Until 1934 they were called "special resettlers", in 1934-1935 the term was "labor settlers" and since March 1944 they were referred to as "special resettlers of 'the former kulak' contingent".

57 V.N. Zemskov, "The fate of "kulak exile" (1930-1954)", Otechestvennaya istoriya, no. 1 (1994): 122.

${ }^{58}$ Only after the war, in 1946-1954, all restrictions previously imposed on the deported peasants were lifted. However, rehabilitation of peasants as victims of political repression was still out of the question.

${ }^{59}$ For more details on the preparation and conduction of the NKVD mass operations, the activities of the troika of the Vologda Oblast NKVD Administration, the Commission of the NKVD and the prosecutor of the USSR, and the special troika of the Vologda Oblast NKVD Adminisrtation, see A.L. Kuzminykh and S.I. Starostin, Poles in Vologda Oblast: repression, captivity, special settlement (1937-1953) (Vologda: Drevnosti Severa, 2014), 23-33. 
They were subject to arrest and incarceration in camps for the term of 8 to 10 years and the most inveterate and socially dangerous of them were to be incarcerated in prisons for the same term by the decision of a troika. Troikas kept minutes of their sessions where they recorded the sentences they passed for each convicted person. The minutes were sent to the heads of operational groups in order to execute the sentences. As a rule, sentences were passed by default, without the accused being present, without the defense and the prosecution, and were not subject of appeal. Executions by shooting were conducted, with "the obligatory secrecy as for the time and place of the execution". 60

Administrative territorial changes of the country were simultaneous with the commencement of the mass terror. On 23 September 1937 a decree of the Central Executive Committee of the USSR divided the Northern Region into Vologda Region and Arkhangelsk Region. The order of the USSR NKVD No. 00623 of 29 September 1937 established the Vologda Region NKVD Administration which comprised 2 raion departments and 21 raion offices of the disbanded Northern Region NKDV Administration and 18 raion offices transferred from the jurisdiction of the Leningrad Region NKVD Administration. ${ }^{61}$ Further conduct of "the kulak operation" was passed over to the newly established NKVD administration and the troika including the chair, Zhupakhin (head of the NKVD administration) and the members, Lyustrov (second secretary of the Region executive committee of VKP(b)) and Savgirov (deputy prosecutor of Vologda Region in charge of special cases).

The Vologda Region NKVD Administration Troika started its work on 2 November 1937 and finished it on 22 September 1938. The total number of people who were subjected to repression was 4 075. Of them 2090 (44.4\%) were sentenced to execution by shooting and 2615 (55.6\%) were sentences to incarceration in corrective labor camps. The number of persons charged with counterrevolutionary crimes was $4524(96.2 \%)$ and more than 4000 of them were listed in the troika's records as "the former kulaks". The number of persons who underwent repression as criminal offenders was $181(3.8 \%)^{62}$

It was quite natural that the peasants exiled to Vologda Region in 1930-1933 were found among the "former kulaks" under repression. In total, 135 labor settlers were subjected to repression by the Vologda Region NKVD Administration Troika, 44 of whom were sentences to execution by shooting and 91 were sentenced to incarceration in labor camps for 10 years.

${ }^{60}$ A.N. Yakovlev, ed., GULAG: Main Administration of Camps. 1918-1960 (Moscow: MFD, 2000), 98, 103.

${ }^{61}$ Arkhiv UMVD Rossii po VO f. 6, op. 1, d. 195, 11. 54-55 ob.

${ }^{62}$ Arkhiv UFSB Rossii po VO f. 10, op. 1, dd. 1, 3, 5, 7, 9, 11, 13, 15, 17, 19, 21, 23, 25, 27, $29,31,33,54,56,60,62,64,65,67,71$. 
For ethnic operations against Poles, Germans, Romanians, Letts, Estonians, Finns, Greeks, Afghans, Iranians, Chinese, Bulgarians, Macedonians and Harbin Russians $^{63}$, who were considered by Stalin's administration as a potential resource of espionage and collaborationism ${ }^{64}$, the so-called "album" procedure of conviction was devised. After the inquest had been finished, an information note on the accused was compiled which included a brief account of the evidence and agent's reports defining the degree of culpability of the arrested person. Separate notes were collected and retyped as a list to be submitted for consideration to the commission comprising two persons (the head of the NKVD administration and the prosecutor) or "dvoika" whose task was to put the accused into one of the two categories: ${ }^{65}$ the first category (execution by shooting) or the second category (incarceration for 5 to 10 years). Then the list was sent to Moscow to be considered and finally approved by the Commission of the NKVD and Prosecutor General of the USSR (N.I. Ezhov and A.Y. Vyshinsky). On approval, the list was returned to the Vologda Region NKVD Administration together with the copy of the minutes of the session of the Commission. The head of the NKVD administration was ordered to execute the persons sentenced to shooting and to send their case files together with certificates of execution to Moscow. Extracts from the minutes of the Special Board of the NKVD of the USSR were sent with regard to the persons sentenced to incarceration in corrective labor camps and their files were also sent to Moscow. ${ }^{66}$ The Vologda Region NKVD Administration was also responsible for executing the decrees of the NKVD Commission and Prosecutor General of the USSR on the "albums" sent to Moscow by the Northern Railway Transport Department of the GUGB NKVD.

In total, in the course of "ethnic" operations, of the cases of the Vologda Region NKVD Administration submitted to Moscow, case papers of 290 persons charged with "subversive and espionage activities" were considered. Of them, 221 were sentenced to capital punishment; 66 were sentenced to 10 years in corrective labor camps; 1 case was referred to the Military Collegium of the Supreme Court of the USSR; and 2 cases were referred to regular courts. ${ }^{67}$ It should be noted that all 22 people subjected to repression in the course of "the Greek operation" were peasants deported to Vologda Region from the Ukrainian SSR and from Crimea in 1930. Of the 31 persons subjected to repression in the course of "the Romanian operation", 14 were kulak labor settlers residing in Kharovsk Raion of Vologda Region. Meanwhile, of the cases of the Northern Railway Transport Department of the GUGB NKVD,

${ }^{63}$ Among them were the former employees of the Chinese Eastern Railway who returned to the USSR after the railway was sold in 1935.

${ }^{64}$ O.V. Khlevnyuk, "The great terror of $1937-1938$ as a problem of scientific historiography", in Historical science and education at the turn of the century (Moscow: Sobranie, 2004), 438.

${ }^{65}$ Similar to those of the "kulak operation."

${ }^{66}$ Arkhiv UFSB Rossii po VO f. 10, op. 1, d. 34, 35.

${ }^{67}$ Arkhiv UFSB Rossii po VO f. 10, op. 1, d. 34. 
case papers of 239 persons were considered, of whom 100 were sentenced to capital punishment; 112, to 10 years in corrective labor camps; 9 , to 5 years in corrective labor camps; 7 cases were referred to the Military Collegium of the Supreme Court of the USSR; 2 cases were referred to the transit court of the Northern Railway; and 6 cases were remitted for further enquiry. ${ }^{68}$ It should be mentioned that of the 14 persons subjected to repression in the course of "the German operation" 11 were peasants deported to the Northern Krai from the Ukrainian SSR in 1930.

Since the spring of 1938 the "ethnic line" operations become the focus of mass repression. However, by September 1938 ethnic "albums" of 126 thousand people still had not been considered by the central apparatus of the NKVD of the USSR. In August 1938 the "album" procedure was abolished. In compliance with the order of the USSR NKVD No. 00606, "special troikas" comprisiong the head of the Region NKDV administration, the first secretary of the Region executive committee and the Region prosecutor were established in each Region, krai or republic in order to consider the remaining cases of those arrested as "counterrevolutionary ethnic contingents." The troikas were to consider the cases of those who had been arrested within the course of ethnic operations before 1 August 1938. The term of the troika's operation was defined as two months. After the order No. 00606 was issued, all "albums" were returned to the local level. ${ }^{69}$

The special troika of the Vologda Region NKVD Administration considered the cases both of NKVD Administration and of the Transit Department of the Northern Railway. The troika started and finished its work in November 1938. During this period the cases of all "ethnic lines" were considered. The results were as follows: 294 people were sentences to execution by shooting; 465 people, to 10 years in corrective labor camps; 46 people, to 8 years in camps; 13 people, to 5 years in camps. The cases of 71 persons were referred to the court martial, the cases of 21 persons were referred to the Special Board of the NKVD of the USSR, and 6 cases were remitted for further enquiry. As it had happened earlier, among the victims of repression were kulak labor settlers (150 persons), of whom 77 were sentences to death; 69, to 10 years of corrective labor camps; 1 , to 8 years. Three cases were referred to the court martial. Of those who underwent repression under "the Bulgarian line" ( 24 people), all were deported peasants; of repression victims under "the Greek line", 13 persons were deported peasants; of repression victims under "the German line", 112 were deported peasants.

On 17 November 1938 all "mass operations" were finished, the activities of the troikas, special troikas, and the Commission of the NKVD and Prosecutor General of

${ }^{68}$ Arkhiv UFSB Rossii po VO f. 10, op. 1, d. 34, 11. 42-45, 56-59; d. 35.

${ }^{69}$ N. Okhotin and A. Roginskii, "From the history of the German operation of the NKVD in 1937-1938", in Repression against Russian Germans. A punished people (Moscow: Zven'ya, 1999), $61-62$. 
the USSR were officially terminated. After that the decisions on all investigatory cases were to be made either by judicial authorities or by the Special Board of the NKVD of the USSR. ${ }^{70}$

Peasants in "kulak exile" in other regions of the country also underwent repression in the course of the "kulak operation". For instance, in 1937-1938 more than 50 people in special settlement in Kandalaksha Raion of Murmansk Region were sentenced to capital punishment. ${ }^{71}$

Because of the formation of Vologda Region all the functions connected with administrative and economic support of labor settlers were assigned to the Department of Places of Detention and Labor Settlements of the Vologda Region NKVD Administration (since 1 January 1939, the Department of Corrective Labor Colonies, Corrective Labor and Labor Settlements of the Vologda Region NKVD Administration). There were no labor settlers in the former raions of Leningrad Region that had been included into Vologda Region. On 1 July 1938 there were 9606 special settlers accommodated in 45 settlements administered by 8 commandant's offices. ${ }^{72}$

It is necessary to point out that some special settlers from among the young people who distinguished themselves at work, took active part in social life and were loyal to Soviet rule were granted civil rights. What is more, some of them, though very few, were able to leave special settlements in order to study at secondary and higher educational institutions.

The beginning of the Second World War and the partition of Poland between Germany and the Soviet Union provided a new stimulus to the expansion of special exile owing to the new categories of special resettlers. In 1940-1941 about 320 thousand Polish citizens (residents of the eastern territories of the pre-war Poland and ref-

${ }^{70}$ M.A. Beznin, ed., Entrusted with protection of the Fatherland. (From the history of security organs in Vologda region) (Vologda: Vologodskii gosudarstvennyi pedagogicheskii universitet, 2008), 302. The decision was based on the decree of the Sovnarkom of the USSR and the Central Committee of VKP(b). On the order of the NKVD of the USSR No. 0062 of 26 November 1938, the orders, directives and decrees of the NKVD on conducting all repressive operations were either deemed expired or cancelled. However, the repression itself went on. According to the statistics of the Vologda Department of the Federal Security Service of Russia, the total number of people arrested in 1937-1940 by the Vologda Oblast NKVD Administration was 10405.

${ }^{71}$ Calculated by the author of the Book of Memory. See S.N. Dashchinskii, V.V. Voronin, and V.A. Nechushkin, eds., Book of Memory. Russian Federation. Murmansk Region. Nominal list of the Kola Peninsula residents who were the victims of repression and foreign citizens who resided in Murmansk Region (Murmansk: Sever, 1997), 13, 16, 19, 31, 35, 38, 43, 47, 55, 63, 66, 71, 76, 78, $80,81,89,94,96,98,103,107,109,117,123,126,132,138,139,150,151,154,159,160,164$, $165,169,171,186,200,201,203,205,207,209,210,219,223,224,227,228,242,244,251,252$, 258, 263, 266, 272-275, 278, 285, 295, 299-300, 304, 311, 317, 323, 326, 328, 335-338, 340, 350, $353,359,364,368-369,379$.

${ }^{72}$ V.N. Zemskov, The fate of "kulak exile", 126. 
ugees from Central Poland occupied by Germany) were deported by the Soviet organs inland the USSR.

Five western Regions of the Belorussian SSR (Viliejka, Baranovichy, Belostok, Brest, Pinsk) and six western Regions of the Ukrainian SSR (Volhynia, Rovno, Lvov, Ternopol, Drohobych, Stanislavov) were formed in the territories of the Republic of Poland annexed by the Soviet Union in September 1939. In 1940 Soviet authorities conducted three large-scale deportation operations to move residents of the western Regions of the Ukrainian SSR and Belorussian SSR to the remote northern and eastern regions of the USSR. In the NKVD records, the Polish citizens ${ }^{73}$ deported in the course of each of the operations were divided into three separate categories: special settlers -osadniks (140-141 thousand people, deported on 10 February 1940); administratively deported "family members of the repressed" (61 thousand people, deported on 13 April 1940); special settlers - refugees (78-79 thousand people, deported on 29 June 1940). ${ }^{74}$

The fourth deportation operation, aimed at the residents of the Moldavian, Lithuanian, Latvian and Estonian SSRs and the western Regions of the Ukrainian and Belorussian SSRs, was conducted in May-June 1941. In NKVD records the exiles comprised the category of deportees. The estimated number of Polish citizens among them may reach 34-44 thousand people. ${ }^{75}$

The deported Polish citizens were kept in special settlements in 13 Regions, 2 krais and 4 autonomous republics of the RSFSR and in 8 Regions of the Kazakh SSR. ${ }^{76}$ Those of them who were settled in Vologda Region ${ }^{77}$ represented two of the

73 The term "Polish citizens" or "Polish special resettlers" is applied to the residents of the eastern territories of the pre-war Polish state who were subjected to repression in 1939-1941 regardless of their ethnic origin and regardless of their state affiliation. During the war the latter became a matter of dispute between the Polish government-in-exile and Soviet authorities who refused to consider these persons as foreigners.

${ }^{74}$ A. Gurjanow, "Cztery deportacje 1940-41", KARTA: Niezależne pismo historyczne (Warszawa), nr. 12 (1994): 114-36; A.E. Gur'yanov, "Polish special resettlers in the USSR in 19401941", in Repression against ethnic Poles and Polish citizens, comp. A.E. Gur'yanov (Moscow: Zven'ya, 1997), 114-36.

${ }^{75}$ A.E. Gur'yanov, "The scale of the deportation of population inland the USSR in May-June 1941", in Repression against ethnic Poles and Polish citizens, comp. A.E. Gur'yanov (Moscow: Zven'ya, 1997), 137-75.

${ }^{76}$ A.E. Gur'yanov, "Polish special settlers in Siberia (1940-1941)", in Siberia in history and culture of Polish people, comp. A. Kuchinskii and P.S. Romanov (Moscow: Ladomir, 2002), 36875.

${ }^{77}$ For more details of the history of Polish deportees staying in the territory of Vologda Region in 1940-1946, see A.L. Kuzminykh and S.I. Starostin, Poles in Vologda Region, 300-27. 
four categories mentioned above: special settlers - osadniks and special settlers - refugees. $^{78}$

Deportation of the families of osadniks and "foresters" $" 79$ was conducted simultaneously during one day, 10 February 1940, in all western Regions of the Ukrainian SSR and Belorussian SSR. On that same day first special trains with special settlers left for the USSR interior. The osadniks (more than 7800 people) who arrived in late February and early March of 1940 were settled in 12 special settlements located in 7 raions of Vologda Region. ${ }^{80}$ Soon (presumably in April 1940) one more special settlement was added to them. It was the settlement of Yavenga (Yavengsky) where some of the special settlers were moved from the settlements of Zelenobrodsky and Zharovsky in Vozhega Raion. ${ }^{81}$ Initially, Yavenga mechanized logging depot was in-

${ }^{78}$ For more details of the procedure of making decisions on the deportation of osadniks and refugees, see N.F. Bugai, Joseph Stalin - Lavrenti Beria: "They are to be deported": documents, facts, commentary (Moscow: Druzhba narodov, 1992); A.E. Gur'yanov, "Polish special resettlers in the USSR" (Moscow: Zven'ya, 1997); A.E. Gur'yanov, "Introduction”, in Polish special settlers in Arkhangelsk Oblast. Index of repression victims. Issue 14, part 1, Alphabetical list of 9320 Polish citizens deported from Bialystok Obalst in 1940, eds. E. Rybarska, A. Gur'yanov, A. Rachinsky and T. Lozinskaya (Warsaw, 2003), 756-73; part 2. Alphabetical list of 8559 Polish citizens deported from Baranovichi and Vileyka oblasts 1940, eds. E. Rybarska, A. Gur'yanov, A. Rachinsky and T. Lozinskaya (Warsaw, 2004), 718-38; N.S. Lebedeva, "Inrtoduction”, in Katyn: prisoners of undeclared war: documents and materials, eds. R.G. Pikhoya and A. Geishtor (Moscow: Demokratiya, 1999), 29-30.

${ }^{79}$ The term 'veteran settlers' ('Osadniks') in Poland referred to the colonists from among the demobilized members of the military in the Polish army, the participants of the Polish-Soviet War in 1919-1920, who got free land allotments from the Polish state in the north-east and eastern voivodeships - Vilenski, Novogudsky, Belostotsky, Polessky and Volynsky Uyezds. Their settlements - 'Osadas' - were neighbouring the Belorussian and Ukrainians settlements, the population of which treated them with suspicion and were even hostile at times. In the eastern territories of Polish Republic (including the south-eastern voivodeships - the Lvov, Tarnopol and Stanislavski Uyezds), there also lived the civilian 'settlers', who bought out the neglected land allotments from the state on preferential terms. To those referred both the colonists who arrived from the other regions of Poland, and the local farmers, thus enlarging their former domains. The operation to displace the families of Osadniks was also carried out in relation to the 'foresters' - the employees of the 'the forests watchman service' together with their families. In the colony-settlement, they were all referred to the category of special settlers - Osadniks.

The category of special settlers - refugees included residents of the part of Poland occupied by Germany, who fled to the territory of the western regions in Ukraine and Belorussia after 1st September 1939 and then indicated their willingness to leave the USSR towards the territory occupied by the Germans, which was however not accepted by the German government, and they were soon expelled to the northern and eastern regions of the Soviet Union.

${ }^{80}$ Arkhiv UMVD Rossii po VO f. 29, op. 2, d. 18, 11. 2-19, 21-54, 56-82, 84-98, 100-161.

${ }^{81}$ The order to organize the special settlement of Yavenga has not been found. In the archival personal files of the majority of special resettlers who stayed there, 24 February 1940 is specified as the date of arrival. As of 15-16 March 1940, all the osadniks who had arrived in the first wave and 
tended for housing free settlers from the western Regions of Ukraine and Belarus, predominantly refugees, recruited by the representatives of "Vologdales" trust to work in timber harvesting. ${ }^{82}$ However, much less recruits arrived than it had been planned, and the settlements for osadniks, especially Zelenobrodsky, appeared to be overcrowded. ${ }^{83}$ Apparently, that was the reason why the recruits were transferred to the other logging enterprises and logging depots of "Vologdales" trust and the osadniks were moved to the Yavenga mechanized logging depot.

The next party of deported Polish citizens arrived in Vologda Region in the first half of July 1940. Most of them were special settlers - refugees. The operation to deport them was conducted simultaneously in all western Regions of the Ukrainian SSR and the Belorussian SSR on 29 June 1940. At the same time with the refugees, a large group of special settlers - osadniks arrived in Vologda Region. The newly arrived osadniks were those who for some reason had not been deported during the main operation on 10 February 1940.

To accommodate special settlers - refugees in Vologda Region 14 special settlements were organized beforehand: Poteryakha and Vozhemka in Nyuksenitsa Raion; Komaritsa and Churilovskii in Tot'ma Raion; Poldarskii and Terekhino in Veliky Ustyug Raion; Murzha in Nikol'sk Raion; Steklyanka in Lezha Raion; Uzhla in Kovzhinsky Raion; Yalegsky in Andomsky Raion; Megorsky and Koshtugsky in Oshta Raion; Itkol'sky in Kirillov Raion; and Kovzhezavodskoi in Shol'sky Raion. Special settlers - refugees started to move in the special settlements on 6 July and finished on 13 July 1940.

To accommodate special settles - osadniks who arrived in June three new settlements were organized, Vetka in Vytegra Raion, Srednyaya Shima in Kovzhinsky Raion and Turnega in Andomsky Raion. Moving into these special settlements took place mainly on 10 July and 15 July 1945.

One more place for confining special settlers in Vologda Region appeared due to the fact that the households of the deported Polish citizens included a lot of persons

were kept in this settlement later, stayed in the settlements of Zelenobrodsky and Zharovsky. So it can be concluded that it is these two settlements where they arrived on 24 February 1940, and the settlement of Yavenga was organized later, between 25 March 1940 (the date of death of Nikolai Moroz, an osadnik, whose family got to Yavenga) and 4 May (the date of birth of two children, who died soon after, in the family of osadnik Mukha). See Arkhiv UMVD Rossii po VO f. 29, op. 2, d. $18,1.56-82$.

${ }^{82}$ Apparently, it was the recruits that were implied in the special message of the head of the Vologda Oblast NKVD Administation P.P. Kondakov of 21 March 1940, who mentioned the arrival of 2004 refugees in Vologda Region (simultaneous with the arrival of special resettlers).

${ }^{83}$ GAVO f. 1727, op. 2, d. 1240, 11. 231, 239-240 ob. About the campaign to recruit refugees in the western oblasts of the Ukrainian SSR and the Belorussian SSR to work in the eastern oblasts, also see A.E. Gur'yanov, "Introduction", in Polish special resettlers in Arkhangelsk Region, part. 1, 757-58; part 2, 719-20; part 3, 811-12. 
incapable of work (the elderly and the disabled) who became a heavy burden to bear both for logging enterprises and for the NKVD organs. The decision of the RSFSR Sovnarkom suggested that Vologda Region Executive Committee and the People's Commissariat of Social Security of the RSFSR should organize a 300-bed home for the disabled Polish citizens in Vologda Region. In compliance with the proposition, on 13 August 1940 the "narrowed down" meeting of Vologda Region Executive Committee decided to establish a home for disabled persons in Semigorodnee Village Soviet of Kharovsk Raion. Kharovsk Special Home started to accept disabled people from among Polish citizens on 2 October 1940. As of 1 January 1941, 102 residents were registered there including 40 women $^{84}$ (according to another data there were 103 persons including 49 were osadniks and 54 refugees). ${ }^{85}$

At the end of October 1940, 605 special settlers - osadniks (108 households) were moved to Volodga Region from special settlements in Shar'ya Raion of Gorky Region. ${ }^{86}$ In order to accommodate them, two more settlements, Onezhsky and Saminsky (Desyatok) were organized in Andomsky Raion. ${ }^{87}$

Thus, by November 1940 the system of special settlements for Polish special resettlers had been formed. It consisted of 34 special settlements ( 20 of them were for osadniks and 14 were for refugees) and one special home for the disabled, which were located in 17 out of the 43 administrative raions of the Region in existence at the time. ${ }^{88}$ Settlement commandant's offices of the settlements in Tot'ma, Ledengskoye (renamed Babushkinsky at the end of February 1941), Vozhega, Kharovsk, Nyuksenitsa and Andomsky raions (20 special settlements in 6 raions) were subordinated to the commandant's offices of their raions and settlement commandant's offices of the other 14 settlements were in direct subordination to the Department of Corrective Labor Colonies which included the Section of Labor Settlements of the Region NKVD administration. As a matter of fact, Andomsky Raion Commandant's Office, which was established by the same order of the head of Vologda Region NKVD Administration that established the Special Settlements Onezhsky and Saminsky, was not approved by the NKVD of the USSR and on 3 June 1941 it had to be closed down. ${ }^{89}$

${ }^{84}$ GAVO f. 2491, op. 6, d. 1, 11. 145-146.

${ }^{85}$ GARF f. 9479 , op. 1 , d. $75,1.5$; d. 88, 11. 88-89.

${ }^{86}$ GARF f. 9479, op. 1, d. 75, 11. 5-5 ob.

${ }^{87}$ Arkhiv UMVD Rossii po VO f. 39, op. 1, d. 1, 1. 508. By the order of the head of the Vologda Oblast NKVD Aministration No. 367 of 14 October 1940.

88 The location of all special settlements is shown on the map and in the catalogue, see A. Gur'yanov and S. Starostin, "Introduction", in Polish special resettlers in Vologda Region. Alphabetical list of 14226 Polish citizens deported from the western oblasts of the Belorussian SSR and Ukrainian SSR in 1940, eds. A. Dzenkevich, E. Rybarsk, A. Gur'yanov, A. Rachinsky and S. Starostin (Warsaw, 2005), 661-62, 688-93.

${ }^{89}$ GARF f. 9479, op. 1, d. 75, 1. 55. 
At the beginning of 1941 there were 13139 special resettlers (9 270 osadniks and 3869 refugees) in Vologda Region who resided in 34 special settlements; ${ }^{90} 103$ more people resided in the special home for the disabled; and 20 were kept in orphanages (16 refugees' children and 4 osadniks' children). ${ }^{91}$ The total number of Polish citizens was 13 262. The number of labor settlers contained in labor settlements of Vologda Region as of 1 January 1941 was significantly smaller and amounted to 9979 people. $^{92}$

At that time Vologda Region ranked sixth by the number of Polish special resettlers after Arkhangelsk Region (53 021 people), Sverdlovsk Region (26 819 people), Novosibirsk Region (19 594 people), Komi ASSR (18 722 people), and Krasnoyarsk Krai (14 989 people), as of 1 January $1941 .^{93}$

The confinement of the persons deported from the western Regions of the Ukrainian SSR and the Belorussian SSR to special settlements in Vologda Region was terminated by their release in compliance with the edict of the Presidium of the Supreme Soviet of the USSR of 12 August 1941 "On Granting Amnesty to Polish Citizens Confined in the Territory of the USSR." 94 After being granted amnesty and struck off the register of special settlement, the released the Polish citizens were granted the right of "free movement on the territory of the Soviet Union, except the borderland along the whole of the USSR frontier, high-security localities of the $1^{\text {st }}$ and $2^{\text {nd }}$ categories, the closed security zone and the USSR martial law districts". ${ }^{9}$

The process of releasing special settlers started on 28 August 1941 and was almost finished on 6 October $1941 .{ }^{96}$ On 13 February 1941 the head of the Region NKDV administration L.F. Galkin ${ }^{97}$ reported to the deputy People's Commissar for Internal Affairs V.N Merkulov that "all Polish citizens with the exception of few individuals had been amnestied" in Vologda Region. ${ }^{98}$

After the amnesty, in compliance with the order of the USSR NKVD No. 001187 of 31 August $1941,{ }^{99}$ all raion and settlement commandant's offices of the NKDV in

${ }^{90}$ Arkhiv UFSB Rossii po VO f. 1pkx., op. 4, d. 7, 1. 6 ob; GARF f. 9479, op. 1, d. 75, 1. 5.

${ }^{91}$ GARF f. 9479 , op. 1 , d. $75,1.5$; d. 88, 11. 88, 89 .

${ }^{92}$ GARF f. 9479 , op. 1, d. 62, 1. 69; d. 88, 1. 95.

${ }^{93}$ GARF f. 9479 , op. 1, d. 62, 11. 68-69.

${ }^{94}$ Decree of the Presidium of the Supreme Soviet of the USSR dated 12.08.1941 "On granting amnesty to the Polish citizens held in state custody on the territory of the USSR": Russian archive: The Great Patriotic War. USSR and Poland: 1941-1945, vol. 14 (3-1), 24 (Moskow: TERRA, 1994).

${ }^{95}$ Arkhiv UMVD Rossii po VO f. 6, op. 1, d. 429, 1. 34.

${ }^{96}$ Some more persons had been released by 15 February 1942.

${ }^{97}$ He held the post since February 1941.

${ }^{98}$ Arkhiv UFSB Rossii po VO f. 1 pkh., op. 5, d. 1, 11. 42-42 ob. According to that report, in addition to special settlers, 100 Polish citizens were released from the prisons and 39 were released from the colonies of Vologda Oblast.

${ }^{99}$ Arkhiv UMVD Rossii po VO f. 6, op. 1, d. 416, 1. 103. 
charge of special resettlers - osadniks, "forresters" and refugees were liquidated and the settlements themselves were placed under the authority of the local logging enterprises.

As of 1 October 1941, there were 9880 labor settlers (3 331 men; 3136 women; 823 teenagers between ages 14 and 16; 2590 children under 14 years of age). ${ }^{100}$ In terms of the number of labor settlers, the Region ranked $18^{\text {th }}$ among the republics, krais and Regions of the USSR. ${ }^{101}$

Not only was the Great Patriotic War the most severe and violent ordeal for our country, but also it exerted great influence on the system of special settlements. For some victims of deportation such as labor settlers ("former kulaks") and special settlers (Polish citizens) the war and first post-war years were marked by liberation from the supervision of the NKVD organs while for the others such as "the punished peoples" (Germans, Chechen, Ingush, Kalmyk, Crimean Tatars, et al.) it was aggravated by mass deportations from the places of permanent residence.

On 28 August 1941 the Department of Special Settlements ${ }^{102}$ was established in the central apparatus of the NKVD of the USSR for the sole purpose of receiving and accommodating the Germans who were being resettled. ${ }^{103}$ On the same day the Presidium of the Supreme Soviet of the USSR issued the edict "On Resettling the Germans Residing in Raions of the Volga Region" which initiated the chain of deportations of the citizens of German ethnicity. In the USSR Germans were deported from almost everywhere wherever it was possible during the war. By the beginning of 1941, 1031.3 thousand Germans were registered as special settlers, of whom 800 thousand were those who had been deported from the European USSR and 231.3 thousand were "local" Germans who had been transferred to the category of "special contingent" but left in their places of residence.

It should be pointed out that during that period the deported Germans were not sent to special settlements in Vologda Region and were not moved to the other re-

${ }^{100}$ GARF F. 9479, op. 1, d. 89, 1. 189-191, cited in V.N. Zemskov, Special Settlers in the USSR, 1930-1960 (Moscow: Nauka, 2005), 98-99.

${ }^{101}$ Altogether, 35 NKVD subdivisions and camps contained 936547 people, of them 272473 were men, 285197 were women, 73280 were teenagers between ages 14 and 16, 305597 were children under 14 years of age.

${ }^{102}$ Arkhiv UMVD Rossii po VO f. 6, op. 1, d. 415, 1. 95.

${ }^{103}$ The department operated in parallel to the GULAG Department of Labor and Special Settlements of the USSR NKVD. It was closed down on 14 November 1942 and its functions were transferred to the GULAG Department of Labor and Special Settlements of the NKVD of the USSR. See A.N. Yakovlev, ed., GULAG: Main Administration of Camps. 1918-1960 (Moscow: MFD, 2000), 31, 270-71. 
gions of the USSR from the territory of the Region. The absolute majority of Germans residing in Vologda Region were labor settlers ("former kulaks"). ${ }^{104}$

In compliance with the order of the USSR NKVD No. 00530 of 16 March 1942, "With the Enunciation of Staff of the Inspectorate Sections, Settlement Commandant's Offices and Special Settlements," the functions of supervision over special settlers in the Vologda Region NKVD Administration were assigned to the Section of Labor and Special Settlements ${ }^{105}$ with a staff of 3 persons: head of the section, senior inspector and inspector. The following commandant's offices were subordinated to the section: Totma raion commandant's office with the staff list of 6 persons ( 1 raion commandant, 4 settlement commandants, 1 clerk-statistician); Vozhega raion commandant's office with the staff list of 5 persons (1 raion commandant, 3 settlement commandants, 1 clerk-statistician); Tarnoga, Syamzha, Chyobsara, Babushkinsky, Nyuksenitsa and Kharovsk settlement commandant's offices, each with a settlement commandant on the staff list. ${ }^{106}$

The issue of using the labor of Germans was of utmost importance in the localities of their new resettlement. One of the ways to solve it was labor mobilization of Germans and formation of the so-called Labor Army the "soldiers" of which were conscripted (mobilized) by military registration and enlistment offices of the People's Commissariat for Defense and sent to work in the areas which, as a rule, were remote from those where their families stayed in special settlements. ${ }^{107}$

Special decrees of the State Defense Committee of the USSR of 10 January, 14 February and 7 October 1942 and 26 April, 2 August and 19 August 1943 on conscription of the deported German population into the Labor Army implied practically wholesale "mobilization" of the able-bodied German population into the Labor Ar-

${ }^{104}$ In September 1941 a draft decree of the State Defense Committee of the USSR was prepared, according to which 302288 Germans from 41 region of the USSR including 696 people from Vologda Region were to be moved to the Kazakh SSR during the period from 20 September 1941 till 10 October 1941. However, the draft was rejected. A series of decrees was issued instead, each of them covering a limited selection of regions. Vologda Region was not mentioned in any of them. See A.N. Yakovlev, ed., Stalin's deportations. 1928-1953 (Moscow: MFD: Materik, 2005), 334-37.

105 Actually, only labor settlements for "former kulaks" remained in existence in Vologda Oblast.

${ }^{106}$ Arkhiv UMVD Rossii po vo f. 6, op. 1, d. 433, 1. 45.

107 A.N. Yakovlev, ed., Stalin's deportations. 1928-1953, 374. In fact, the formation of the Labor Army started in September 1941 when construction battalions of the NKVD were reorganized into labor columns, which implied living in the barracks and the routine of a camp. The first Germans to be mobilized into the Labor Army were the Red Army Germans who had been withdrawn from the acting army. Since September 1941 they were listed as special settlers. They were not demobilized but sent to the Labor Army which combined the elements of military formations, labor, and GULAG-like routine. By the beginning of 1942 there were actually 20.8 thousand Germans in the Labor Army. 
my. ${ }^{108}$ It should be noted that the first two decrees concerned men between 17 and 50 years of age while the third decree referred to men between ages 15 and 55 as well as women between ages 16 and 45 except for pregnant women and mothers of children under 3 years of age. Failure to report for mobilization, refusal to work or sabotage inflicted most severe punishment, even execution by shooting. ${ }^{109}$

From the very beginning, according to their departmental affiliation militarized labor columns and detachments of mobilized Germans were divided into two different types. One type was represented by those which were organized and located in camps and at construction sites of the GULAG of the USSR NKDV and were guarded and catered for in compliance with the standards established for prisoners. The others were formed at the civil people's commissariats and agencies, were subordinated to their leadership but were controlled by the NKVD organs. Administrative regulations of such formations were less severe than those of the columns and detachments functioning within the NKVD itself. ${ }^{110}$ The archival documents show that the Germans mobilized in the territory of Vologda Region were sent to the labor columns of the first type and the columns of mobilized Germans who stayed in Vologda Region belonged to the second type.

Thus, according to the instruction of the deputy People's Commissar of Internal Affairs S.N. Kruglov, 278 German residents of Vologda Region were conscripted into labor duty. ${ }^{111}$ All of them were sent to work in the Northern Railway Corrective Labor Camp $^{112}$ of the USSR NKVD.

According to the decree of the State Defense Committee No. 2383ss of 7 November 1942 it was planned to send 300 Germans ${ }^{113}$ to harvest timber for "Neftetara" trust in Vologda Region. The mobilized Germans arrived at the enterprises of Volog-

108 The term "Labor Army" was not in official use, the conscription was into "NKVD Labor Columns."

${ }^{109}$ P. Polian, Against their will, 114.

110 A.N. Kurochkin, "Labor Army units formed from the USSR citizens of German ethnicity during the years of the Great Patriotic War (1941-1945)" (PhD thesis, Saratov Higher Military School of Rocket Forces, 1998), 66.

${ }^{111}$ Arkhiv UFSB Rossii po VO f. 1pkh., op. 5, d. 15, 11. 28-28 ob.

112 The Northern Railway Labor Camp (Sevzheldorlag) was established on 10 May 1938 and closed down on 24 June 1950 (it was united with the North-Pechora Corrective Labor Camp into a new camp, Pechora Corrective Labor Camp). It was located in the village of Knyazh-Pogost in UstVymsky Raion of Komi ASSR. The camp worked at the construction of the Kotlas-Vorkuta railway, in particular, at Kotlas-Ust-Kozhva $(728 \mathrm{~km})$, Konosha-Kotlas, Velsk-Kotlas-Kozhva, and other sections of the railway. As of 1 July 1942, German labor columns counted 4954 persons; as of 1 November 1942, 5411 persons; as of 1 January 1947, 1130 Germans conscripted into labor duty and then transferred into special settlements. See M.B. Smirnov, ed., The system of corrective labor camps in the USSR. 1923-1960: a reference book (Moscow: Zven'ya, 1998), 380-81.

${ }^{113}$ GARF f. 9479, op. 1, d. 111, 1. 43, quoted in N.F. Bugai, Mobilize Germans into labor columns, 80 . 
da Region in the winter of 1943 from Arkhangelsk Region (150 people, 100 of whom were sent to Mezhdurechensky mechanized logging depot (Vokhtoga junction station) and 50, to Sokolsky saw mill) and Ivanovo Region (103 people, of whom 53 men were sent to Mezhdurechensky mechanized logging depot (Vokhtoga junction station) and 50 women, to Sokolsky mill of "Neftetara"). ${ }^{114}$

In compliance with the order of the USSR NKVD No. 01021, the control over the organization of the routine and labor use as well as registration of the mobilized Germans employed by the enterprises of People's Commissariats was assigned to the GULAG of the NKVD of the USSR. ${ }^{115}$

According to the statistics of the Vologda Region Corrective Labor Camps and Colonies Administration of the NKVD, as of 1 January 1944, there were 238 mobilized Germans (34 men and 204 women) in Vologda Region. ${ }^{116}$ As of 1 September 194, their number increased to 329 persons, the overwhelming majority of them being women (see Table 1).

Table 1

The location of the Germans mobilized as industrial workers as of 1 September $1945^{117}$

\begin{tabular}{|c|c|c|c|c|c|}
\hline \multirow{2}{*}{$\begin{array}{l}\text { Name of the } \\
\text { raion and its } \\
\text { administrative } \\
\text { center }\end{array}$} & \multirow{2}{*}{$\begin{array}{l}\text { Name of the point of settlement } \\
\text { (distance from the raion } \\
\text { administrative center, } \mathrm{km} \text { ) }\end{array}$} & \multicolumn{3}{|c|}{ Number } & \multirow{2}{*}{$\begin{array}{l}\text { Work } \\
\text { done }\end{array}$} \\
\hline & & total & men & women & \\
\hline \multirow{3}{*}{$\begin{array}{l}\text { Sokol, } \\
\text { the town of } \\
\text { Sokol }\end{array}$} & "Neftetara" factory $(0 \mathrm{~km})$ & 52 & 1 & 51 & making staves \\
\hline & "Imeni Sverdlova" factory $(0 \mathrm{~km})$ & 78 & - & 78 & wood harvesting \\
\hline & Total & 130 & 1 & 129 & \\
\hline $\begin{array}{l}\text { Lezhsky, } \\
\text { the settlement } \\
\text { of Sidorovo }\end{array}$ & $\begin{array}{l}\text { "Neftetara" factory of the } \\
\text { Mexhdurechensky mechanized } \\
\text { logging depot }(60 \mathrm{~km})\end{array}$ & 91 & 23 & 68 & making staves \\
\hline \multirow[t]{2}{*}{$\begin{array}{l}\text { Vytegra, } \\
\text { the town of } \\
\text { Vytegra }\end{array}$} & $\begin{array}{l}\text { The settlement of Belorucheisky } \\
\qquad(23 \mathrm{~km})\end{array}$ & 108 & - & 108 & $\begin{array}{l}\text { mining topo- } \\
\text { graphic works }\end{array}$ \\
\hline & Total in the oblast & 329 & 24 & 305 & \\
\hline
\end{tabular}

The Labor Army as such was liquidated only in January-March $1946 .{ }^{118}$ The released Labor Army "soldiers" (mobilized Germans) remained bound to the enterprises where they had worked but were granted the right to send for their families.

${ }^{114}$ GARF f. 9479, op. 1, d. 111, 1. 47, 85, quoted in N.F. Bugai, Mobilize Germans into labor columns, 212-13, 215.

${ }^{115}$ Arkhiv UMVD Rossii po VO f. 24, op. 1, d. 1, 1. 10.

${ }^{116}$ Arkhiv UMVD Rossii po VO f. 24, op. 1, d. 17, 1. 46.

${ }^{117}$ Arkhiv UMVD Rossii po VO f. 24, op. 1, d. 17, 1. 129 
Over the years of the Great Patriotic War, the number of labor settlers decreased preeminently because of conscripting them into the Red Army. During the first months of the war military registration and enlistment offices of several krais and Regions conscripted labor settlers into regular military units and construction battalions. The total number of the conscripts was 3 761, of them 391 persons were conscripted in Vologda Region. ${ }^{119}$

On 11 April 1942 the State Defense Committee of the USSR adopted the decree No. 1575 ss according to which 35 thousand people from among the resettlers of military age were to be conscripted into the Red Army in the period from 15 April till 15 May 1942. The decree of the State Defense Committee No. 2100ss of 22 June 1942 increased the planned number of conscripts up to 50 thousand people. By 1 November 1942 the conscription of labor settlers into the Red Army had been finished. In total, since the beginning of the war 60747 labor settlers had been conscripted into the army (57 324 of them, in 1942) including 679 people from Vologda Region (which made $20.4 \%$ of all men of military age who resided in the territory of the Region) ${ }^{120}$.

In compliance with the order of the USSR NKVD No. 002303 of 22 October 1942, all conscripted labor settlers their family members were to be crossed off the register, received their passports and were exempted from five percent deduction from their salaries. As of 21 June 1943, 677 households (2 648 people) were crossed off the register, of them 995 men, 489 women and 1164 children. ${ }^{121}$ Judging by the memoranda and special reports of the Vologda Region NKVD Administration, the general military conscription of the former labor settlers was well-organized. The appearance at conscription stations was timely. Most conscripts showed a positive attitude towards mobilization and considered it as an expression of confidence of the authorities and many of them demonstrated patriotism and readiness to fight the enemy.

In the same way as the other defenders of the fatherland did, the former kulaks fought the enemy without regard to their own lives. Many of them did not come back from the battle fields; many were decorated with medals and orders. Two of the former labor settlers were bestowed the title Hero of the Soviet Union: Mikhail Porfir'evich Berestovenko (conscripted from the settlement of Kharovsk in Kharovsk

${ }^{118}$ Arkhiv UMVD Rossii po VO f. 24, op. 1, d. 2, 1. 13.

${ }^{119}$ GARF f. 9479, op. 1, d. 113, 1. 4-5, quoted in V.N. Zemskov, Special Settlers in the USSR, 102.

${ }^{120}$ V.N. Zemskov, "The fate of "kulak exile" in 1940-1954", in Population of Russia in the $20^{\text {th }}$ century, vol. 2. 1940-1959 (Moscow: ROSSPEN, 2001), 297-98; GARF f. 9479, op. 1, d. 113, 1. 215 .

${ }^{121}$ GARF f. 9479, op. 1, d. 113, 1. 211. 
Raion) and Ivan Yakovlevich Krasnik (conscripted from the village of Zimnyak in Nyuksenitsa Raion). ${ }^{122}$

In compliance with the directive of the NKVD of the USSR No. $52 / \mathrm{v}-761$ of 13 April 1943, 240 "former kulaks"123 were mobilized and sent to Vyatka Corrective Labor Camp ${ }^{124}$ of the NKVD of the USSR (Kirov Region). ${ }^{125}$ In the autumn of 1943, 98 more labor settlers were removed to Arkhangelsk Region for mine timber shipping at Ust-Shonosha timber-handling complex of Glavsnables [Main Directorate for Supplying the National Economy with Timber and Firewood] under the SNK of the USSR (Ust-Shonosha station of the North Pechora Railway). ${ }^{126}$

In March 1944 the Department of Special and Labor Settlements was withdrawn from the GULAG and renamed "the Department of Special Settlements of the NKVD of the USSR". As a result, labor settlers were referred to as special settlers (special resettlers) ${ }^{127}$ in the departmental documents thereafter. The functions of the Department of Special Settlements of the NKVD of the USSR and its territorial organs were the following: a) assistance in job placement and accommodation of special settlers; b) efficient cheka servicing of special settlers; c) registration and administrative supervision over special settlers in the places of their settlement.

The order of the NKVD of the USSR No. 0170 of 16 August 1944 enforced the instruction to register special settlers. ${ }^{128}$ It was necessary to quantify the households and the number of special settlers, to ensure the control over their movements within the raions of settlement, to identify able-bodied persons, and monitor their job placement. Registration was to facilitate timely detection of escapes and answering the inquiries of the organs of the NKVD, the NKGB, counterintelligence of the People's

${ }^{122}$ P.K. Perepechenko and G.I. Sokolov, eds., Citizens of Vologda-Heroes of the Soviet Union (Vologda: Severo-Zapadnoe knizhnoe izdatel'stvo, 1970), 54-55, 176-78.

${ }^{123}$ The group included both Germans and people of other ethnic origins.

${ }^{124}$ Vyatka Corrective Labor Camp (Vyatlag) was organized on 5 February 1930. At present, one of the institutions of the Kirov Oblast Administration of the Federal Penitentiary Service of Russia operates at the site of the camp (it is located in the settlement of Lesnoe of Kirov Oblast). Vyatlag specialized in timber harvesting, woodworking, construction and maintenance of branch railway lines for timber carrying, et al. The detachments of mobilized Germans were formed on 12 January 1942. See M.B. Smirnov, ed., The system of corrective labor camps in the USSR. 19231960: a reference book (Moscow: Zven'ya, 1998), 200-01.

${ }^{125}$ Arkhiv UMVD Rossii po VO f. 24, op 1, d. 17, 1. 110-110 ob. As of July 1945, Vyatlag contained 140 inmates, the rest of them either had died or had been sent back to Vologda Oblast.

${ }^{126}$ Arkhiv UMVD Rossii po VO f. 24, op. 1, d. 17, 1. 110; N.F. Bugai, “Mobilize Germans into labor columns, 228-29. In compliance with the directive of the NKVD of the USSR No. 1/10401 of 5 June 1944 they were transferred for registration to the Department of Special Settlements of the Arkhangelsk Region NKVD Administration.

${ }^{127}$ Arkhiv UMVD Rossii po VO f. 6, op. 1, d. 454, 1. 195.

${ }^{128}$ Arkhiv UMVD Rossii po VO f. 6, op. 1, d. 455, 11. 288-295. 
Commissariat of Defense and the People's Commissariat of the Navy, Smersh, and soviet and party organs.

All contingents of special settlers and every single person were subject to registration by special commandant's offices, raion departments of the NKVD and the departments of special settlers of the Region NKVD administrations. Registration records were to be made in special cards: card No. 1 was a family card to register heads of the families; card No. 2 was a personal card to register each special settler except for the heads of the families and children under 16 years of age; card No. 3 was an aggregate card to register children under 16 years of age. The cards (of the standard size of $95 \mathrm{~mm}$ by $140 \mathrm{~mm}$ ) were filled in compliance with the passports (the old passports were confiscated and the new ones were issued, which contained a record permitting residence within a certain raion), marriage certificates, birth certificates, lists of the special trains, certificates of acceptance of special settlers, sentences or resolutions of judicial bodies and other official documents. If the documents were not available, the cards were completed by means of questioning special settlers and contained the note saying "completed according to oral information". Two copies of the cards were filled in: one was for the card file of raion NKVD departments and the other was for the reference card file of the Department of Special Settlers of the Vologda Region NKVD Administration. The Department of Special Settlers compiled a single alphabetical reference card file based on the cards.

The front and back pages of a family card contained information about the head of the family and the inner pages contained information about family members. The information specified the date and place of birth, relation to the head of the family, ethnic origin, profession, occupation before deportation, date of arrival at the site of settlement and ability to work.

As a result of registration, it was established that as of 1 October 1944 there were 4858 "former kulaks", 362 Germans and 1357 Chechens and Ingush ${ }^{129}$ staying in Vologda Region.

North Caucasian special settlers arrived in Vologda Region in the autumn of 1944 from the Kazakh SSR where they had been mobilized by the local military registration and enlistment offices to work in timber harvesting. On arrival in Vologda Region they were sent to "Cherepovetsles" trust under the People's Commissarital of Timber Industry and to Monzensky logging enterprise. ${ }^{130}$

In compliance with the order of the Vologda Region NKVD Administration No. 0063 of 20 July $1944^{131}$ four temporary commandant's offices were established for accommodating and servicing them: Belorucheisky (Vytegra Raion, the settle-

129 GARF f. 9401. op. 2. d. 86. 11. 64-65 ob., quoted in A.I. Kokurin, "Special settlers in the USSR in 1945, or the Year of great resettlement”, Otechestvennye arkhivy, no. 5 (1993): 109-10.

${ }^{130}$ Arkhiv UMVD Rossii po VO f. 8, op. 1, d. 55, 1. 10.

${ }^{131}$ Arkhiv UMVD Rossii po VO f. 7, op. 1, d. 11, 11. 86-87. 
ment of Bely Ruchei); Konevo (Shol'sky Raion, the settlement of Konevo); Kovzhinsky (Kovzhinsky Raion, the settlement of Annensky Most); Vokhtoga (Lezhsky Raion, Vokhtoga railway station). In addition to Vologda Region NKVD officials, the commandant's offices were serviced by military groups of the Red Army NKVD troops. As of the $1^{\text {st }}$ quarter of 1945, their number amounted to 12 persons, of whom in Belorucheisky, 4 persons (475 special settlers); in Kovzhinsky, 2 persons (289 special settlers); in Konevo, 3 persons (189 special settlers); in Monzensky, 3 persons (170 special settlers). ${ }^{132}$

The special settlers were not ready to work in timber harvesting; they had neither warm clothes and footwear nor the experience of working in the woods. The logging enterprises were not able to supply them with everything that was necessary. In consequence, North Caucasians failed to produce the established output quotas and earned poor sustenance. These factors together with harsh climatic conditions had a pernicious effect on the physical condition of the special settlers and resulted in mass cold-related diseases, dystrophy and high mortality rate (see Table 2).

Table 2

\section{Dynamics of the mortality rate among the special settlers from the North Caucasus ${ }^{133}$}

\begin{tabular}{|c|c|c|c|}
\hline Quarter & $\begin{array}{c}\text { Number at the } \\
\text { beginning of the quarter }\end{array}$ & $\begin{array}{c}\text { Number } \\
\text { of the deceased }\end{array}$ & $\begin{array}{c}\text { Percent of the } \\
\text { total number }\end{array}$ \\
\hline $4^{\text {th }}$ quarter of 1944 & 1358 persons & 186 persons & 13,7 \\
\hline $1^{\text {st }}$ quarter of 1945 & 1123 persons & 331 persons & 29,4 \\
\hline $2^{\text {nd }}$ quarter of 1945 & 774 persons & 92 persons & 11,8 \\
\hline Total over the period & 1358 persons & 609 persons & 44,8 \\
\hline
\end{tabular}

At the beginning of 1945, only 556 persons (49.5\%) of the total number of special settlers ( 1123 persons) were capable of work and only 186 of them (18\%) were working. ${ }^{134}$ As of 25 January 1945, a great number of special settlers (705 persons) were emaciated and suffered from severe dystrophy. Living conditions of special settlers slightly improved only in March 1945. Supply level of staple foods (meat and cereals) was increased twice and the delivery of fats and sugar became regular. By 1 April 1945 dystrophy cases had stopped but mortality rate still remained high (92 persons died in the first quarter of 1945) and 284 persons were sick. ${ }^{135}$

\footnotetext{
${ }^{132}$ Arkhiv UMVD Rossii po VO f. 24, op. 1, d. 17, 1. 22.

${ }^{133}$ Arkhiv UMVD Rossii po VO f. 8, op. 1, d. 55, 1. 10; d. 56, 11. 23-24.

${ }^{134}$ Arkhiv UMVD Rossii po VO f. 8. op. 1, d. 54, 11. 25-26.

${ }^{135}$ Arkhiv UMVD Rossii po VO f. 24, op. 1. d, 17, 1. 47.
} 
Instances of escape from the location of settlement and theft of food, vegetables and cattle from the local residents were of mass scale. From the moment of arrival till 1 April 1945, 34 special settlers escaped, of whom 33 were detained (criminal proceeding were instituted against 30 persons). ${ }^{136}$

Neither the heads of the Region NKVD Administration nor the Department of Special Settlers of the USSR NKVD was happy with the situation. The attention of logging enterprises executives, Region bodies of executive authority and the party organs was brought to the issue of the unsatisfactory condition of the North Caucasian special settlers more than once but there was no response. In the end, the Department of Special Settlements of the USSR NKVD resolved to send the remaining 678 special settlers who were still alive back to the Kazakh SSR.

Initially, boarding and departure of special train was scheduled for 8 April 1945. However, it was impossible to transport special settlers from Vytegra, Sholsky and Kovzhinsky raions to Cherepovets railway station because of spring slush and significant distance (about $300 \mathrm{~km}$ ). The departure was postponed until the beginning of shipping season ${ }^{137}$. The train with North Caucasian special settlers (641 persons) departed from Vologda to Alma Ata as late as on 30 May 1945. The only persons who were left in Vologda Region were the individuals serving their sentences in the institutions of confinement and hospitalized patients (37 persons). ${ }^{138}$ On release or recovery they were also sent to Kazakhstan one by one.

The decree of the SNK of the USSR No. 34-14s of 8 January 1946 approved "Regulations of Special Commandant's Offices of the NKVD". ${ }^{139}$ The establishment of special commandant's offices was aimed at providing state security, keeping public order and preventing the escapes of special resettlers from the locations of settlement, supervision over the accommodation and job placement of special resettlers. Special commandant's offices were to be formed in the areas of settlement and were to be located in the center of the territory where the deportees were settled. The direct guidance of the activities of special commandant's offices was provided be the raion departments of the NKVD in accordance with their territorial affiliation.

Special commandants were charged with the following: registration of special resettlers and supervision over them in order to prevent escape from settlement and to identify anti-Soviet and criminal elements; organizing and conducting search for escapees; preventing and suppressing unrest in the settlements; exercising control over accommodation and job placement of special resettlers in the places of settlement; accepting complaints and applications from special resettlers and taking necessary measures thereon; issuing permits allowing special resettlers to temporarily leave the

\footnotetext{
${ }^{136}$ Arkhiv UMVD Rossii po VO f. 24, op. 1. d, 17, 1. 31.

${ }^{137}$ Arkhiv UMVD Rossii po VO f. 24, op. 1. d, 17, 1. 41-42.

${ }^{138}$ Arkhiv UMVD Rossii po VO f. 24, op. 1. d, 17, 1. 98.

139 A.N. Yakovlev, ed., Stalin's deportations. 1928-1953, 561-62.
} 
area of settlement serviced by a certain Commandant's Office without the right to leave the raion.

The commandants were granted the right to impose disciplinary action (such as a fine up to 100 rubles or an arrest up to 5 days) on those special resettlers who broke rules of conduct and public order. Besides, the commandants were charged with investigating the cases of escapees and other crimes committed by special resettlers.

Legal status of special settlers was ultimately defined by the decree of the SNK of the USSR No. 35 of 8 January 1945. They were vested with all rights of the USSR citizens except for the restrictions specified in the decree. They were not allowed to leave the raion of settlement without the permission of the commandant of the NKVD special commandant's office. Unauthorized absence from the settlement was viewed as escape and entailed criminal responsibility. Heads of the households (or the persons they were replaced by) were obliged to report any changes in the household (birth of a child, death of a family member, escape, etc.) to the NKVD special commandant's office within three-day term. Special resettlers were to strictly observe the established rules of conduct and public order in the locations of settlement and obey all orders and directions of the NKVD special commandant's offices. ${ }^{140}$

In 1945 the number of special settlers in Vologda Region changed significantly. As it was mentioned above, in compliance with the instructions of the USSR NKVD, all Chechens and Ingush were returned to special settlements in the Kazakh SSR. In April 1945 families of "OUN members" (the participants of Ukrainian nationalist organizations "Organization of Ukrainian Nationalists" and "Ukrainian Insurgent Army") arrived in Vologda Region for special settlement. ${ }^{141}$ In October 1945 special trains started to arrive bringing the Germans who had been transported to Austria, Germany, Poland and Czechoslovakia in the years of the Great Patriotic War. According to the directive of the USSR NKVD No. 181 of 11 October 1945, all repatriated Soviet citizens of German ethnicity were to be sent to special settlements under the supervision of the NKVD organs. ${ }^{142}$

${ }^{140}$ A.N. Yakovlev, ed., Stalin's deportations. 1928-1953, 563.

${ }^{141}$ Arkhiv UMVD Rossii po VO f. 24, op. 1, d 17, 1. 48-49. The OUN-UPA members themselves were not in the contingent that included mainly women and children. Thus, 155 OUN-UPA households, which counted 379 persons (91 man, 163 women, 125 children under 16 years of age), arrived in Vologda Region on 23 April 1945.

${ }^{142}$ Arkhiv UMVD Rossii po VO f. 24, op. 1, d. 2, 11. 72-74. 


\section{Arrival of special settlers in Vologda Region in $1945-1946^{143}$}

\begin{tabular}{|c|c|c|c|c|c|}
\hline $\begin{array}{l}\text { Special } \\
\text { train } \\
\text { no. }\end{array}$ & $\begin{array}{l}\text { Date and station } \\
\text { of departure } \\
\text { (Region } \\
\text { of deportation) }\end{array}$ & $\begin{array}{c}\text { Date and station } \\
\text { of arrival }\end{array}$ & $\begin{array}{l}\text { Contin- } \\
\text { gent }\end{array}$ & $\begin{array}{l}\text { Number } \\
\text { (persons) }\end{array}$ & $\begin{array}{l}\text { Enterprises (raions), } \\
\text { where special settlers } \\
\text { were sent for accom- } \\
\text { modation and job } \\
\text { placement }\end{array}$ \\
\hline 1 & 2 & 3 & 4 & 5 & 6 \\
\hline 47467 & $\begin{array}{c}- \\
\text { Lvov }\end{array}$ & $\begin{array}{c}23.04 .1945 . \\
\text { Cherepovets } \\
\text { station }\end{array}$ & $\begin{array}{l}\text { "OUN } \\
\text { mem- } \\
\text { bers" }\end{array}$ & 379 & $\begin{array}{c}\text { State farm } \\
\text { "Komsomolets" } \\
\text { (Cherepovets Raion) }\end{array}$ \\
\hline- & $\begin{array}{c}- \\
\text { Lvov }\end{array}$ & $\begin{array}{l}24 \text { July } 1945 \\
\text { Kotlas station }\end{array}$ & $\begin{array}{l}\text { "OUN } \\
\text { mem- } \\
\text { bers" }\end{array}$ & 434 & $\begin{array}{c}\text { Udimsky logging en- } \\
\text { terprise of "Ustyugles" } \\
\text { trust } \\
\text { (Veliky Ustyug Raion) }\end{array}$ \\
\hline 96582 & $\begin{array}{l}26 \text { Sept. } 1945 \\
\text { the city of Brest }\end{array}$ & $\begin{array}{c}08 \text { Oct. } 1945 \\
\text { Vologda station }\end{array}$ & Germans & 2107 & $\begin{array}{l}\text { Logging enterprise of } \\
\text { "Vologdobumles" trust } \\
\text { (Totma, Babushkinsky, } \\
\text { Biryakovo, } \\
\text { Mezhdurechensky } \\
\text { raions) }\end{array}$ \\
\hline 97153 & $\begin{array}{l}07 \text { Oct. } 1945 \\
\text { the city of Brest }\end{array}$ & $\begin{array}{c}20 \text { Oct. } 1945 \\
\text { Vologda station }\end{array}$ & Germans & 2174 & $\begin{array}{c}\text { Logging enterprise of } \\
\text { "Vologdobumles" trust } \\
\text { (Kharovsk, } \\
\text { Vozhega raions) }\end{array}$ \\
\hline 97156 & $\begin{array}{c}10 \text { Oct. } 1945 \\
\text { the city of Brest }\end{array}$ & $\begin{array}{l}21 \text { Oct. } 1945 \\
\text { Cherepovets } \\
\text { tation }\end{array}$ & Germans & 2233 & $\begin{array}{l}\text { Sheksna logging enter- } \\
\text { prise, Sheksna shipping } \\
\text { company, Sukhonsky } \\
\text { shipping company un- } \\
\text { der the People's Com- } \\
\text { missariat of the River } \\
\text { and Marine Fleet }\end{array}$ \\
\hline 97146 & $\begin{array}{c}15 \text { Oct. } 1945 \\
\text { the city of } \\
\text { Grodno }\end{array}$ & $\begin{array}{l}24 \text { Oct. } 1945 \\
\text { Kotlas station }\end{array}$ & Germans & 2167 & $\begin{array}{c}\text { Udimsky logging en- } \\
\text { terprise } \\
\text { of “Ustyugles trust } \\
\text { (Veliky Ustyug Raion) }\end{array}$ \\
\hline $\begin{array}{c}97 \\
153^{144}\end{array}$ & $\begin{array}{c}07 \text { Oct. } 1945 \\
\text { the city of Brest }\end{array}$ & $\begin{array}{l}03 \text { Nov. } 1945 \\
\text { Vologda station }\end{array}$ & Germans & 138 & $\begin{array}{c}\text { Logging enterprise of } \\
\text { "Vologdobumles" trust } \\
\text { (Kharovsk, } \\
\text { Vozhega raions) }\end{array}$ \\
\hline
\end{tabular}

${ }^{143}$ Arkhiv UMVD Rossii po VO f. 24, op. 1, d. 17, 11. 48-49, 116, 133-134, 138, 140, $144-$ 147, 150, 157-158, 161-162; d. 4, 11. 51, 56.

${ }^{144}$ Three cars of the special train No. 97153, uncoupled en route because of technical problems. 
Continuation of the table 3

\begin{tabular}{|c|c|c|c|c|c|}
\hline 1 & 2 & 3 & 4 & 5 & 6 \\
\hline $\begin{array}{l}97149 / \\
97147\end{array}$ & $\begin{array}{l}29 \text { Oct. } 1945 \\
\text { the town of } \\
\text { Vawkavysk }\end{array}$ & $\begin{array}{c}05.11 .1945 \text { г. } \\
\text { Cherepovets sta- } \\
\text { tion }\end{array}$ & Germans & 1859 & $\begin{array}{l}\text { Belorucheisky logging } \\
\text { enterprise of } \\
\text { "Cherepovetsles" trust } \\
\text { (Vytegra Raion) }\end{array}$ \\
\hline 97132 & $\begin{array}{l}26 \text { Oct. } 1945 \\
\text { the city of Brest }\end{array}$ & $\begin{array}{c}11 \text { Nov. } 1945 \\
\text { Vokhtoga station }\end{array}$ & Germans & 2343 & $\begin{array}{l}\text { Monzensky logging } \\
\text { enterprise under the } \\
\text { People's Commissariat } \\
\text { of Timber Industry } \\
\text { (Lezhsky Raion) }\end{array}$ \\
\hline 51579 & - & $\begin{array}{c}15 \text { Nov.1945 } \\
\text { Vologda station }\end{array}$ & Germans & 1411 & Volodga Raion \\
\hline 50209 & $\begin{array}{l}- \\
\text { the city of } \\
\text { Grodno }\end{array}$ & $\begin{array}{l}28 \text { March } 1946 \\
\text { Kotlas station }\end{array}$ & Germans & 1316 & $\begin{array}{l}\text { Krasavino textile mill } \\
\text { (Veliky Ustyug Raion) }\end{array}$ \\
\hline 97079 & $\begin{array}{c}- \\
\text { Rovno }\end{array}$ & $\begin{array}{l}28 \text { March } 1946 \\
\text { Kotlas station }\end{array}$ & $\begin{array}{l}\text { "OUN } \\
\text { mem- } \\
\text { bers" }\end{array}$ & 533 & $\begin{array}{l}\text { Krasavino textile mill } \\
\text { (Veliky Ustyug Raion) }\end{array}$ \\
\hline
\end{tabular}

On the arrival of "OUN members" and repatriated Germans new special commandant's offices were established in Veliky Ustyug Raion, Biryakovo Raion, Vytegra Raion, Kadui Raion, Kirillov Raion, Lezhsky Raion, Mezhdurechensky Raion and Cherepovets Raion, and additional special commandant's offices were organized in Babushkinsky Raion, Tot'ma Raion, and Kharovsk Raion of Vologda Region $^{145}$. In March 1946 a settlement of particular treatment for escape-prone special settlers was organized in Syamzha Raion. ${ }^{146}$

As of 1 January 1946, there were 19835 persons (4 424 kulaks, 14371 repatriated Germans, 708 "OUN members", 332 mobilized Germans) in special settlement in Vologda Region. The majority of them were women and children (see table 4). Special settlers resided in 171 settlements subordinated to 29 NKVD special commandant's offices. ${ }^{147}$

145 Arkhiv UMVD Rossii po VO f. 7, op. 1, d. 12, 11. 112, 304, 379-380, 398; d. 13, 11. 28-29, 46, 49, 149.

${ }^{146}$ Arkhiv UMVD Rossii po VO f. 7, op. 1, d. 13, 1. 45.

${ }^{147}$ Arkhiv UMVD Rossii po VO f. 24, op. 1, d. 4, 11. 32-38. The special settlers who resided in Ustyuzhna Raion and Kovzhensky Raion were under the control of the raion NKVD departments, and those who resided in Vologda Raion were under the control of the Department of Special Settlers of the Vologda Oblast NKVD Administration. 
The number of special settlers in Vologda Region as of 1 January 1946

\begin{tabular}{|c|c|c|c|c|c|}
\hline $\begin{array}{c}\text { Registration } \\
\text { category }\end{array}$ & $\begin{array}{c}\text { Number of } \\
\text { households }\end{array}$ & $\begin{array}{c}\text { Number of } \\
\text { persons }\end{array}$ & Men & Women & $\begin{array}{c}\text { Children under } \\
16\end{array}$ \\
\hline Kulaks & 2176 & 4424 & 1462 & 1826 & 1136 \\
\hline Germans & 4108 & 14371 & 2246 & 5661 & 6464 \\
\hline $\begin{array}{c}\text { Mobilized } \\
\text { Germans }\end{array}$ & - & 332 & 24 & 308 & - \\
\hline "OUN members" & 283 & 708 & 149 & 304 & 255 \\
\hline Total & 6567 & 19835 & 3881 & 8099 & 7855 \\
\hline
\end{tabular}

In June 1947 the former kulaks, except for ethnic Germans, ${ }^{148}$ were released from special settlements of Vologda Region on the grounds of the order of the USSR MVD No. $00519^{149}$ of 16 May 1947 and the orders of the Vologda Region MVD Administration No. 0047 of 27 May 1947 and No. 0050 ${ }^{150}$ of 31 May 1947.

The decree of the Council of Ministers of the USSR of 22 February $1948^{151}$ ordered the removal to Siberia and the Kazakh SSR of the total of 82.5 thousand people from among the deportees confined in special settlements in the European part of the USSR including 10297 persons from Vologda Region. However, the secretary of the Vologda VKP(b) Region Committee and the chair of the Vologda Executive Committee petitioned for leaving special resettlers in Vologda Region. Minister of Internal Affairs of the USSR S.N. Kruglov seconded the petition and special resettlers were left in place. ${ }^{152}$

In compliance with the edict of the Presidium of the Supreme Soviet of the USSR of 26 November 1948, special settlers (German repatriates and German who had been deported and mobilized during the Great Patriotic War as well as "OUN members") were to stay in special settlement forever with no right to return to the previous place of residence. ${ }^{153}$

As of 1 February 1949, there were 23 special commandant's offices in Vologda Region: 3 in Totma Raion (Tot'ma, Shakhto-Pechengsky, Churilovo); 1 in Babushkinsky Raion (Obirkovsky); 1 in Nyuksenitsa Raion (“Zimnyak”); 4 in Veliky Ustyug Raion (Severny, Privodninsky, Krasavino, Tozemsky); 2 in Vozhega Raion

148 A.N. Yakovlev, ed., Stalin's deportations. 1928-1953, 758-59. One hundred and five Germans who were "former kulaks" were left in special settlement.

${ }^{149}$ Arkhiv UMVD Rossii po VO f. 6, op. 1, d. 493, 1. 766.

${ }^{150}$ Arkhiv UMVD Rossii po VO f. 7, op. 1, d. 14, 11. 106, 110-111.

${ }^{151}$ GAFR f. 9479, op. 1, d. 371, 1. 4, quoted in N.F. Bugai, L. Beria - J. Stalin: “According to your orders", 224.

152 N.F. Bugai, Joseph Stalin - Lavrenti Beria: "They are to be deported”, 82-83.

${ }^{153}$ E.A. Zaitsev, ed., Collection of legislative and regulatory acts relative to the persecution and rehabilitation of the victims of political repression (Moscow: Respublika, 1993), 124. 
(Enalsky, Pigomsky); 2 in Kharovsk Raion (Semigorodnensky, Mitinsky); 1 in Mezhdurechensky Raion (the settlement of Shichenga); 2 in Lezhsky Raion (Lezhsky, Vos'evsky); 1 in Cherepovets Raion; 1 in Vytegra Raion; 1 in Biryakovo Raion; 1 in Babaevo Raion; 1 in Kirillov Raion; 1 in Kovzhinsky Raion; 1 in Vologda Raion.

In compliance with the order of the USSR MVD No. 00165 of 19 February 1949 "About the Organization of the Personal Registration of Exiles and Special Resettlers under the New System" "154 all special settlers who resided in Vologda Region were reregistered. All special settlers who had been subjected to resettlement on ethnic grounds were referred to the category of "deportees". Since that time on, to keep records of them, the following kinds of registration were established in special commandant's office: registration by family in special books and personal registration of those who escaped from the territory of the special commandant's office, temporarily left or temporarily arrived. In addition to registration books, the commandants kept registers of the presence of deportees. Members of deportees' families who were not deportees themselves but were married to a deportee were not to be included into the books of registration by family; female deportees married to non-deportees were not struck off the register. It was necessary to record all departures, including children who left for studies. On finishing school, they could be directed to work to the regions of settlement of the contingent they belonged to and were subject to obligatory registration.

Town, city and raion departments of the MVD were charged with personal card registration according to Form No. 5 (brief). They also kept missing person files of the deportees who had escaped from the territory of the raion. Personal record files of all adult deportees of 16 years of age and older were kept. In addition to the available information, the files were based on the questionnaires which had been completed during re-registration.

Vologda Region MDV Administration departments collected all records by family and personal records (according to Form No. 6, detailed) of deportees and the First Special Department of the USSR MVD kept the card file of specialized personal registration. The First Department received alphabetical and registration cards of the persons who were new arrivals in special settlement, departed for other locations, were released, died, were arrested, escaped, or were placed in homes for the disabled. As a result, in was established that 9364 adults and children resided in special settlements, of them 8818 were Germans and 546 were "OUN members".

Vologda Region MDV departments collected all by-family and personal records (according to Form No. 6, detailed) of deportees and the $1^{\text {st }}$ special department of the USSR MVD kept the card file of specialized personal registration. The $1^{\text {st }}$ department received alphabetical and registration cards of the persons who were new arrivals in

${ }^{154}$ Arkhiv UMVD Rossii po VO f. 6, op. 1, d. 529, 11. 85-104. 
special settlement, departed for other locations, were released, died, were arrested, escaped, or were placed in homes for the disabled. As a result, in was established that 9364 adults and children resided in special settlement, of them 8818 were Germans and 546 were "OUN members".

Table 5

Number and categories of special settlers in Vologda Region in 1941-1950 (as of 1 January of each year) ${ }^{155}$

\begin{tabular}{|c|c|c|c|}
\hline Year & Categories & Number of persons & Total \\
\hline 1941 & $\begin{array}{c}\text { Labor settlers } \\
\text { Special resettlers }\end{array}$ & $\begin{array}{c}9978 \\
13139 \text { (9270 osadniks } \\
\text { and } 3869 \text { refugees })\end{array}$ & 23117 \\
\hline 1942 & Labor settlers & - & - \\
\hline 1943 & Labor settlers & 5835 & 5835 \\
\hline 1944 & Labor settlers & 5051 & 5051 \\
\hline 1945 & $\begin{array}{l}\text { "Former kulaks" } \\
\text { North Caucasians } \\
\text { "Mobilized Germans" }\end{array}$ & $\begin{array}{c}4699 \\
1123 \\
354^{156}\end{array}$ & 6176 \\
\hline 1946 & $\begin{array}{c}\text { "Former kulaks" } \\
\text { "Mobilized Germans" } \\
\text { German Repatriates } \\
\text { "OUN members" }\end{array}$ & $\begin{array}{c}4424 \\
332 \\
14371 \\
708 \\
\end{array}$ & 19835 \\
\hline 1947 & $\begin{array}{c}\text { "Former kulaks" } \\
\text { Germans } \\
\text { (mobilized and repatriated) } \\
\text { "OUN members" }\end{array}$ & $\begin{array}{c}3954 \\
15132 \\
(14932+200) \\
1184\end{array}$ & 20270 \\
\hline 1948 & $\begin{array}{c}\text { Germans } \\
\text { "ONU members" }\end{array}$ & $\begin{array}{c}12016 \\
988\end{array}$ & 13004 \\
\hline 1949 & $\begin{array}{c}\text { Germans } \\
\text { "OUN members" }\end{array}$ & $\begin{array}{c}9520 \\
843 \\
\end{array}$ & 10363 \\
\hline 1950 & $\begin{array}{c}\text { Germans (repatriated, mobilized, } \\
\text { kulaks, locals) } \\
\text { "OUN members" } \\
\text { "vlasovites" }\end{array}$ & $\begin{array}{c}9339 \\
(9069+141+116+13) \\
824 \\
2\end{array}$ & 10165 \\
\hline
\end{tabular}

${ }^{155}$ Arkhiv UFSB Rossii po VO f. 1pkh., op. 4, d. 7, 1. 6 ob; GARF f. 9479, op. 1. d. 62, 1. 69; d. 75, 1. 5; d. 88, 1. 95; V.N. Zemskov, Special Settlers in the USSR, 106; Arkhiv UMVD Rossii po VO f. 8, op. 1, d. 54, 11. 28-30; d. 57, 1. 19; d. 62, 1. 6; d. 66, 1. 13; f. 24, op. 1, d. 4, 1. 8; d. 5, 1. 39; d. $6,1.26$; d. 7, 1. 7; d. 9, 11. 139, 142, 145 .

${ }^{156}$ N.F. Bugai, Mobilize Germans into labor columns, 11. In the preface to the referred above collection of documents devoted to the history of forced mobilization of German population during the Great Patriotic War, N.F. Bugai notes that 6665 Germans who had been mobilized into Labor Columns and battalions worked in timber harvesting in Vologda Region. In fact, during the war (as of 1945) their maximum number was 354 persons and was decreasing afterwards. The author may have added to them those German repatriates who had been sent to logging enterprises of the region for labor use. 
In 1950 special settlers - "OUN members" were transferred to Irkutsk Region in compliance with the instruction of the USSR MVD. Only those of them who were sick, disabled or married to local residents stayed in Vologda Region. ${ }^{157}$

The decision of the Council of Ministers of the USSR No. 3077-1286ss of $14 \mathrm{Ju}-$ ly 1950 brought the Department of Special Settlements of the USSR MVD and all its local subdivisions under the authority of the USSR MGB (the Ninth Department) which was charged with the guidance of the work related to special settlers. ${ }^{158}$ After the amalgamation of the MVD and the MGB under the order of the USSR MVD No. 00153 of 25 April 1953, Department "P" was established within the structure of the USSR MVD. The responsibilities assigned to Department "P" were the following: organization of registration and registering exiled and deported special settlers; security administration and cheka supervision; checking the initial agents' reports on hostile activities of special contingents; escape prevention and retrieval of escapees. ${ }^{159}$

In compliance with the decree of the Council of Ministers of the USSR of $13 \mathrm{Au}-$ gust 1954 and the order of the USSR MVD No. 00713 of 20 August 1954, German special settlers (former kulaks and those mobilized into industry) were struck off the register of special settlement. ${ }^{160}$ Consequently, the number of special commandant's offices reduced to 20 and the number of special settlers reduced to 5711 persons. ${ }^{161}$

On 30 October 1954 Department "P" was renamed "the Fourth Special Department of the USSR MVD" and similar changes took place on the local level. Sections of the Special Department guided and controlled security administration and supervision in the places of settlement, considered cases, complaints and applications for removal from the register of special settlement; kept statistical records and prepared reports; kept reference card files; controlled the legality of confinement in the places of settlement and the execution of decisions about release from special settlements; issued warrants for special settlement or exile; considered the cases of disabled dangerous special state criminals in order to decide if they were to be placed in homes for the disabled or resigned to the care of their relatives. ${ }^{162}$

157 Arkhiv UMVD Rossii po VO f. 24, op. 1, d. 9, 11. 142-143; d. 10, 1. 226. In April-May 1950, 265 households of "OUN members" (572 persons, of them, 117 men, 309 women and 146 children under 16 years of age) were sent to Irkutsk Oblast. As of 1 January 1952, 168 "OUN members" (51 men and 117 women) were registered in special settlement records. Of them, 6 persons resided in special settlements; 20 persons stayed in homes for the disabled; 1 person was listed as an escapee; 141 persons were detained in institutions of confinement.

${ }^{158}$ Arkhiv UMVD Rossii po VO f. 6, op. 1, d. 548, 11. 267-270.

159 R.G. Pikhoya, ed., Lubyanka. VChK-OGPU-NKVD-NKGB-MGB-MVD-KGB. 1917-1960: reference book, comps. A.I. Kokurin and N.V. Petrov (Moscow: MFD, 1997), 73.

${ }^{160}$ In total, 191 special settlers were crossed off the records of personal registration (67 former kulaks, 141 mobilized persons, and 9 local residents); 3264 children of special settlers were crossed off the records of registration by family.

${ }^{161}$ Arkhiv UMVD Rossii po VO f. 24, op. 1, d. 20, 11. 22-31.

162 A.S. Smykalin, Colonies and prisons in Soviet Russia (Moscow: Yustitsiya, 2016), 195. 
Remaining in special settlements 5644 adult Germans who had been repatriated from Germany and deported during the Great Patriotic War were struck off the register and released from the administrative supervision of the bodies of internal affairs in January-February 1956 in compliance with the order of the Presidium of the Supreme Soviet of the USSR of 13 December 1955 and the order of the USSR MVD No. 0601 of 16 December $1955 .{ }^{163}$ Consequently, 20 special commandant's offices operating in Vologda Region at the time were liquidated and the Fourth Special Department of the Vologda Region MVD Administration was disbanded.

\section{Conclusion}

During Khrushchev's Thaw the authorities condemned the personality cult of J. Stalin and shed some dim light on the true dimensions of political repression. Gradual process of rehabilitation of those who had suffered the tyranny of the state during the years of Stalinism started. In mid-1950s hundreds of thousands of the citizens of our country who had been convicted on preposterous charges were cleared of the stigma of being an "enemy of the people". Nevertheless, the authorities continued to view mass deportations of population on class, social, ethnic, religious and other grounds as a historical regularity caused by the conditions of the historical development of the Soviet State.

Only after the adoption of the Law of the Russian Federation No. 1761-1 of October 18, 1991 "On Rehabilitation of Victims of Political Repression" forced administrative exile of hundreds of thousands of peasants and members of the "punished peoples" together with their family members to special settlement under the supervision of the organs of the OGPU-NKVD-MGB-MVD of the USSR was recognized as political repression. From 1992 till 2017 the Vologda Region MVD Administration considered 24877 applications of citizens for rehabilitation the verification of which resulted in issuing 10899 certificates of rehabilitation for the citizens who had undergone repression by administrative order as well as for the members of their families (see Table 6).

163 Arkhiv UMVD Rossii po VO f. 24, op. 1, d. 16. 11. 29-30. On 18 February 1956 Colonel N.F. Shevarov, Head of the Vologda Oblast MVD Administration, reported to the Fourth Special Department of the USSR MVD and to the Fourth Special Department of the RSFSR MVD that the Vologda Oblast MVD Administration struck off the register of special settlement and released from the supervision of MVD organs 5425 German repatriates, 92 Germans who had been deported to special settlements during the Great Patriotic War, and 127 Germans serving sentences for counterrevolutionary and other crimes. In addition to that, 7 "OUN members" residing in homes for the disabled were released. 
Table 6

The activities of the Vologda Region MVD Administration in rehabilitation of the victims of political repression (1992-2017) ${ }^{164}$

\begin{tabular}{|c|c|c|c|c|}
\hline Year & $\begin{array}{c}\text { Number } \\
\text { of applications }\end{array}$ & $\begin{array}{l}\text { Rehabilitated } \\
\text { (persons) }\end{array}$ & $\begin{array}{c}\text { Recognized as victims of political } \\
\text { repression } \\
\text { (persons) }\end{array}$ & $\begin{array}{c}\text { Rehabilitation } \\
\text { denied } \\
\text { (persons) }\end{array}$ \\
\hline 1992 & 892 & 535 & - & 66 \\
\hline 1993 & 1902 & 756 & 138 & 148 \\
\hline 1994 & 4516 & 1450 & 961 & 359 \\
\hline 1995 & 5999 & 1614 & 432 & 2140 \\
\hline 1996 & 3964 & 3043 & 14 & 697 \\
\hline 1997 & 1677 & 988 & 21 & 450 \\
\hline 1998 & 981 & 490 & 22 & 338 \\
\hline 1999 & 437 & 233 & 3 & 158 \\
\hline 2000 & 375 & 182 & 4 & 103 \\
\hline 2001 & 530 & 340 & - & 80 \\
\hline 2002 & 517 & 244 & - & 137 \\
\hline 2003 & 401 & 163 & - & 103 \\
\hline 2004 & 325 & 107 & - & 63 \\
\hline 2005 & 245 & 87 & - & 54 \\
\hline 2006 & 193 & 64 & - & 41 \\
\hline 2007 & 189 & 69 & - & 57 \\
\hline 2008 & 213 & 89 & - & 38 \\
\hline 2009 & 178 & 85 & - & 29 \\
\hline 2010 & 287 & 73 & - & 68 \\
\hline 2011 & 233 & 88 & - & 89 \\
\hline 2012 & 179 & 34 & - & 45 \\
\hline 2013 & 183 & 51 & - & 49 \\
\hline 2014 & 162 & 43 & - & 31 \\
\hline 2015 & 138 & 37 & - & 10 \\
\hline 2016 & 119 & 30 & - & 18 \\
\hline 2017 & 42 & 4 & - & 11 \\
\hline Total & 24877 & 10899 & 1595 & 5382 \\
\hline
\end{tabular}

Thus, in the course of forcible collectivization of agriculture at the beginning of the $1930 \mathrm{~s}$ of the $20^{\text {th }}$ century masses of peasants were deported from the territory of the present-day Vologda Region to the remote areas of the country (Komi ASSR, Murmansk Region, Siberia, the Far East). At the same time Vologda Region became one of the regions of the Soviet Union where a network of special settlements was formed. Thousands of Soviet and foreign citizens and members of their families subjected to repression spent long years of their life under the supervision of the internal

164 Tekushchii arkhiv Informatsionnogo tsentra UMVD Rossii po Vologodskoi oblasti d. 50, t. $2,1.120$. 
affairs bodies in special settlement under the conditions of limited rights and freedoms. Further research of the deportations and the fates of the deportees will make it possible to define the number of the victims of Stalinist regime in our region more accurately and will facilitate their rehabilitation.

\section{Литература}

Адибеков Г.М. Спецпереселенцы - жертвы «сплошной коллективизации». Из документов «особой папки» политбюро ЦК ВКП(б). 1930-1932 гг. // Исторический архив. 1994. № 4. C. $145-180$.

Артемова O.B. Спецпереселенцы в Вожегодском районе (1930-е годы) // Вожега: краеведческий альманах. Вологда: Русь, 1995. С. 195-220.

Белковец Л.П. Административно-правовое положение российских немцев на спецпоселении, 1941-1955 гг.: историко-правовое исследование. М.: РОССПЭН, 2008. 359 с.

Бердинских В.А. Спецпоселенцы. Политическая ссылка народов Советской России. Киров: Кировская областная типография, 2003. $527 \mathrm{c}$.

Бердинских В.А., Бердинских И.В., Веремьев В.И. Система спецпоселений в Советском Союзе 1930-1950-х годов. М.: РОССПЭН, 2017. 503 с.

Бугай Н.Ф. Депортация народов Крыма: документы, факты, комментарии. М.: ИНСАН, 2002. $240 \mathrm{c}$.

Бугай Н.Ф. Иосиф Сталин - Лаврентию Берии: «Их надо депортировать...»: документы, факты, комментарии. М.: Дружба народов, 1992. 288 с.

Бугай Н.Ф. Л. Берия - И. Сталину: «Согласно Вашему указанию...»: [О депортации народов в СССР в 30-40-е гг.]. М.: АИРО-ХХ, 1995. 320 с.

Бугай Н.Ф. «Мобилизовать немцев в рабочие колонны... И. Сталин»: сборник документов (1940-е годы). М.: Готика, 1998. 350 с.

Бугай Н.Ф., Гонов А.М. Кавказ: народы в эшелонах (20-60-е годы). М.: ИНСАН, 1998. $368 \mathrm{c}$.

Вавулинская Л.И. Спецпереселенцы и иностранные военнопленные в Карелии в середине 1940-х - середине 1950-х гг. Петрозаводск: Карельский научный центр РАН, 2013. 337 с.

Bamкаy H.Э. Женщина в трудармии // Проблемы истории Второй мировой войны. Сборник научных работ / под ред. В.В. Судакова, Б.В. Петелина, С.А. Тихомирова, С.Н. Цветкова. Вологда: Вологодский государственный университет, 2000. С. 82-98.

Вашкау Н.Э. Российские немцы в «трудовой армии»: вклад в Победу // Воинский подвиг защитников Отечества: традиции, преемственность, новации. Материалы межрегиональной научно-практической конференции. Ч. 3 / под ред. В.В. Судакова, В.Б. Конасова. Вологда: Вологодский институт развития образования, 2000. С. 200-207.

Виола Л. Крестьянский ГУЛАГ: мир сталинских спецпоселений. М.: РОССПЭН, 2010. $335 \mathrm{c}$.

Вологжане - Герои Советского Союза: сборник / сост. П.К. Перепеченко, Г.И. Соколов. Вологда: Северо-Западное книжное издательство, 1970. 432 с.

Гинцберг Л.И. Массовые депортации крестьян в 1930-1931 годах и условия их существования в Северных краях (по материалам «особых папок» политбюро ЦК ВКП(б) и «комиссии Андреева» // Отечественная история. 1998. № 2. С. 190-196.

Гинцберг Л.И. По страницам «особых папок» политбюро ЦК ВКП(б) // Вопросы истории. 1996. № 8. С. 16-30. 
ГУЛАГ в Карелии: сборник документов и материалов (1930-1941) / сост. А.Ю. Жуков, В.Г. Макуров и И.Г. Петухова. Петрозаводск: Карельский научный центр РАН, 1992. 225 с.

ГУЛАГ: Главное управление лагерей. 1918-1960 / под ред. А.Н. Яковлева; сост. А.И. Кокурин, Н.В. Петров. М.: МФД, 2000. 888 с.

Гурьянов А.Э. Введение // Польские спецпереселенцы в Архангельской области. Ч. 1. (Индекс репрессированных. Выпуск XIV). Варшава: Центр Карта, Информационный центр УВД Архангельской области, «Мемориал», 2003. С. 754-810.

Гурьянов А.Э. Масштабы депортации населения в глубь СССР в мае-июне 1941 г. // Репрессии против поляков и польских граждан / сост. А.Э. Гурьянов. М.: Звенья, 1997. С. 137175.

Гурьянов А.Э. Польские спецпереселенцы в Сибири (1940-1941) // Сибирь в истории и культуре польского народа / сост. А. Кучинский и П.С. Романов. М.: Ладомир, 2002. С. 368375.

Гурьянов А.Э. Польские спецпереселенцы в СССР в 1940-1941 гг. // Репрессии против поляков и польских граждан / сост. А.Э. Гурьянов. М.: Звенья, 1997. С. 114-136.

Доброноженко Г.Ф. Коллективизация на Севере. 1929-1932 гг. Сыктывкар: Сыктывкарский университет, 1994. 194 с.

Доброноженко Г.Ф. Проведение сплошной коллективизации в Северном крае (19291932 гг.): дис. ... канд. ист. наук. Петрозаводск, 1993. 279 с.

Доброноженко Г.Ф., Шабалова Л.С. Кулацкая ссылка в Коми области в первой половине 1930-х годов // Покаяние: мартиролог. Т. 4. Ч. 1. Сыктывкар: Коми книжное издательство, 2001. С. 15-123.

Доверено охранять Отечество. (Из истории органов безопасности в Вологодском крае) / ред и сост. М.А. Безнин. Вологда: Вологодский государственный педагогический университет, 2008. $581 \mathrm{c}$.

Земсков В.Н. «Кулацкая ссылка» в 1930-е годы: численность, расселение, состав // Население России в ХХ веке / отв. ред. Ю.А. Поляков. М.: РОССПЭН, 2000. Т. 1. С. 277-310.

Земсков В.Н. Депортация населения. Спецпоселенцы и ссыльные. Заключенные // Население России в ХХ веке / отв. ред. Ю.А. Поляков. М.: РОССПЭН, 2000. Т. 2. С. 166-196.

Земсков В.Н. Спецпоселенцы в СССР, 1930-1960. М.: Наука, 2005. 306 с.

Земсков В.Н. Судьба «кулацкой ссылки» (1930-1954 гг.) // Отечественная история. 1994. № 1. C. $118-147$.

Земсков В.Н. Судьба «кулацкой ссылки» в 1940-1954 гг. // Население России в XX веке / отв. ред. Ю.А. Поляков. М.: РОССПЭН, 2001. Т. 2. С. 291-311.

Ивницкий Н.A. Коллективизация и раскулачивание: начало 30-х гг. М.: Интерпракс, 1994. $267 \mathrm{c}$.

Ивниџкий Н.А. Репрессивная политика советской власти в деревне (1928-1933). М.: Институт российской истории РАН, 2000. 350 с.

Ивницкий Н.А. Судьба раскулаченных в СССР. М.: Собрание, 2004. 296 с.

Игнатова Н.М. Периодизация процесса спецпереселения в Республике Коми // Актуальные проблемы краеведения Республики Коми: тезисы докладов / отв. ред. М.А. Мацук. Сыктывкар: Общество изучения Коми края; Министерство по делам национальностей Республики Коми, 1997. С. 32-33.

Игнатова Н.М. Призыв трудпереселенцев в СССР на фронт в 1942 г. // Вопросы истории. 2013. № 11. С. 97-103.

Игнатова Н.M. Принудительный труд спецпереселенцев как системный фактор индустриального освоения северных регионов в 1930-1950 гг. // История сталинизма: Принуди- 
тельный труд в СССР. Экономика, политика, память: материалы международной научной конференции. Москва, 28-29 октября 2011 г. / отв. ред. Л.И. Бородкин, С.А. Красильников, О.В. Хлевнюк. М.: РОССПЭН, 2013. С. 433-449.

Игнатова Н.М. Смертность спецпереселенцев в Северном крае в 1930-е гг.: причины, масштаб, статистический учет // Новый исторический вестник. 2011. № 2 (28). С. 42-52.

Игнатова H.M. Социальный протест спецпереселенцев в Архангельской области и Республике Коми в 1941-1945 гг. // Защитники Отечества: материалы XV региональных общественно-научных чтений по военно-исторической тематике. Архангельск: Правда Севера, 2004. С. $148-156$.

Игнатова Н.M. Социальный протест спецпереселенцев в Северном крае в 1930-1936 гг. // Двинская земля: материалы межрегиональных общественно-научных историкокраеведческих Стефановских чтений. Котлас: Правда Севера, 2002. С. 81-89.

Игнатова Н.M. Спецпереселенцы в Республике Коми в 1930-1940-е гг.: заселение и условия жизни // Корни травы: сборник статей молодых историков / под ред. Л.С. Ереминой, Е.Б. Жемковой. М.: Звенья, 1996. С. 23-35.

Игнатова Н.М. Спецпереселенцы в Республике Коми в 1930-1950-е годы. Сыктывкар: Коми научный центр Института языка, литературы и истории, 2009. 192 с.

Из истории раскулачивания в Карелии, 1930-1931 гг.: документы и материалы / сост. Л.И. Драздович, А.Ю. Жуков, В.Г. Макуров, О.А. Никитина и А.Т. Филатова. Петрозаводск: Карелия, 1991. 295 с.

История сталинского ГУЛАГа. Т. 5: Спецпереселенцы в СССР / отв. ред. и сост. Т.В. Царевская. М.: РОССПЭН, 2004. 824 с.

Катынь: пленники необъявленной войны: документы и материалы / под ред. Р.Г. Пихои, А. Гейштора; сост. Н.С. Лебедева, Н.А. Петросова, Б. Вощинский, В. Матерский. М.: Демократия, 1999. 608 с.

Книга памяти: Российская Федерация, Мурманская область. Поименный список репрессированных жителей Кольского полуострова, а также иностранных граждан, проживавших в Мурманской области / сост. С.Н. Дащинский, В.В. Воронин, В.А. Нечушкин. Мурманск: Север, 1997. 412 с.

Кокурин А.И. Спецпереселенцы в СССР в 1944 году, или Год большого переселения // Отечественные архивы. 1993. № 5. С. 102-110.

Кокурин А.И., Петров Н.В. ГУЛАГ: структура и кадры // Свободная мысль - ХХІ. 1999. № 8. С. 109-128.

Кокурин А.И., Петров Н.В. ОГПУ (1929-1934 гг.) // Свободная мысль - XXI. 1998. № 8. C. $95-114$.

Коллективизация сельского хозяйства в Северном районе (1927-1937 гг.): сборник документов. Вологда: Северо-Западное книжное издательство, 1964. 696 с.

Коллективизация сельского хозяйства в Северо-Западном районе (1927-1937 гг.) / сост. В.А. Селезнев, А.Я. Старикова; под ред. канд. ист. наук Н.А. Ивницкого. Ленинград: [Б. и.], 1970. $424 \mathrm{c}$.

Конасов В.Б., Судаков В.В. Эхо минувшей войны: из истории Вологодской области. Вологда: Институт повышения квалификации и профессиональной переподготовки кадров, 1994. $89 \mathrm{c}$.

Красильников С.А. Серп и молох. Крестьянская ссылка в Западной Сибири в 1930-е годы. М.: РОССПЭН, 2003. 288 с. 
Красильников С.А., Саламатова М.С., Ушакова С.Н. Корни и щепки. Крестьянская семья на спецпоселении в Западной Сибири в 1930-х - начале 1950-х гг. М.: РОССПЭН, 2010. $326 \mathrm{c}$.

Кузьминых А.Л., Старостин С.И. Польские военнопленные и спецпереселенцы в Вологодской области (1939-1941 гг.) // Россия - Польша: филологический и историко-культурный дискурс: сборник статей участников Международной научной конференции (Магнитогорск, 18-19 ноября 2005 г.) / отв. ред.-сост. С.Т. Шулежкова. Магнитогорск: Магнитогорский государственный университет, 2005. С. 104-111.

Кузьминых А.Л., Старостин С.И. Поляки в Вологодской области: репрессии, плен, спецпоселение (1937-1953 гг.). Вологда: Древности Севера, 2014. 688 с.

Курочкин А.Н. Трудармейские формирования из граждан СССР немецкой национальности в годы Великой Отечественной войны (1941-1945 гг.): автореф. дис. ... канд. ист. наук. Саратов: Военное училище ракетных войск, 1998. 19 с.

Лесная промышленность Коми АССР: сборник документов, 1917-1960. Сыктывкар: Коми книжное издательство, 1989. 294 с.

Лубянка. ВЧК-ОГПУ-НКВД-НКГБ-МГБ-МВД-КГБ. 1917-1960: справочник / под ред. Р.Г. Пихоя, сост. А.И. Кокурин, Н.В. Петров. М.: МФД, 1997. 352 с.

Никитина О.А. Коллективизация и раскулачивание в Карелии: автореф. дис. ... канд. ист. наук. Институт Российской истории РАН, 1993. 22 с.

Охотин Н., Рогинский А. Из истории «немецкой операции» НКВД 1937-1938 гг. // Репрессии против российских немцев. Наказанный народ. М.: Звенья, 1999. С. 35-74.

Политбюро и крестьянство: высылка, спецпоселение. 1930-1940. Кн. 1 / отв. ред. Н.Н. Покровский. М.: РОССПЭН, 2005. 912 с.

Политбюро и крестьянство: высылка, спецпоселение. 1930-1940. Кн. 2 / отв. ред. Н.Н. Покровский, В.П. Данилов, С.А. Красильников, Л. Виола. М.: РОССПЭН, 2006. 1120 с.

Польские спецпереселенцы в Вологодской области. Алфавитные списки 14226 польских граждан, высланных в 1940 г. из западных областей БССР и УССР / сост. А. Дзенкевич, Э. Рыбарска, А. Гурьянов, А. Рачинский и С. Старостин. Индекс репрессированных. Вып. XVII. Варшава: Центр КАРТА, 2005. 703 с.

Полян П.М. Не по своей воле...: История и география принудительных миграций в СССР. М.: ОГИ-Мемориал, 2001. 328 с.

Поморский мемориал: Книга памяти жертв политических репрессий / под ред. В.Т. Белова, О.И. Корытовой, В.С. Цыварева. Архангельск: Поморский государственный университет, 1999. Т. 1.869 с.

Рогачев М.Б. Депортация польских граждан в Коми АССР (1940-1941 гг.) // Поляки в России: история ссылки и депортации: тезисы докладов и материалы. СПб., 1995. С. 31-46.

Рогачев М.Б. Страницы польской трагедии: факты и документы // Покаяние. Мартиролог. Т. 5 / сост. М.Б. Рогачев. Сыктывкар: Коми книжное издательство, 2002. С. 14-463.

Сборник законодательных и нормативных актов о репрессиях и реабилитации жертв политических репрессий / сост. Е.А. Зайцев. М.: Республика, 1993. 222 с.

Сборник законодательных и нормативных актов о репрессиях и реабилитации жертв политических репрессий / сост. В.С. Кулагина, В.А. Щепаков. Курск: Курск, 1999. Ч. 1. 510 с.

Система исправительно-трудовых лагерей в СССР. 1923-1960: справочник / сост. М.Б. Смирнов. М.: Звенья, 1998. 597 с.

Спецпереселенцы в Западной Сибири, весна 1931 - нач. 1933 г.: сборник документов / сост. С.А. Красильников и др.; отв. ред. В.П. Данилов, С.А. Красильников. Новосибирск: ЭКОР, 1993. $341 \mathrm{c}$. 
Сталинские депортации. 1928-1953 / под общ. ред. А.Н. Яковлева; сост. Н.Л. Поболь, П.М. Полян М.: МФД: Материк, 2005. 904 с.

Старостин С.И. Депортированные советские и иностранные граждане в годы Великой Отечественной войны (на материалах Архангельской и Вологодской областей) // 1941-1945: уроки войны - уроки правды, мужества и патриотизма: материалы межрегиональной научнопрактической конференции (г. Вологда, 24-25 февраля 2005 г.). Вологда: Русь, 2006. С. 101112.

Старостин С.И. Документы архива УВД Вологодской области о судьбах депортированных граждан СССР и других стран // Историческое краеведение и архивы: материалы межрегиональной научной конференции. Вып. 10 / под ред. А.В. Камкина, О.А. Наумовой. Вологда: Полиграфист, 2004. С. 184-196.

Старостин С.И. История советской ссылки на Европейском Севере: 1930-1956 гг. (на материалах архивов Вологодской области) // История и перспективы уголовноисполнительной системы России: сборник материалов научно-практического семинара (г. Вологда, 4 апреля 2002 г.). Вологда: Вологодский институт права и экономики Минюста России, 2002. С. 98-106.

Старостин С.И. Переселение поляков из Вологодской области (1944 год) // Историческое краеведение и архивы: материалы областной научно-практической конференции 18 марта 2010 г. Вып. 17 / под ред. А.В. Камкина, О.А. Наумовой. Вологда: Полиграфист, 2010. C. 138-145.

Старостин С.И. Структура и функции администрации спецпереселенческих поселков Вологодской области в 1930-1956 годы // Историческое краеведение и архивы: сборник статей. Вып. 9 / под ред. А.В. Камкина, О.А. Наумовой. Вологда: Полиграфист, 2003. С. 109125.

Старостин С.И. Трагические страницы истории. Точка еще не поставлена... // Историческое краеведение и архивы: материалы V и VI научно-практических конференций. Вып. 5. Вологда: Полиграфист, 1999. С. 67-76.

Суслов А.Б. Спецконтингент в Пермской области (1929-1953 гг.). М.: РОССПЭН. 2010. $424 \mathrm{c}$.

Трагедия советской деревни. 1927-1939 гг. Т. 2. Ноябрь 1929 - декабрь 1930. М.: РОССПЭН, 2000. 927 с.

Указ ПВС СССР от 12.08.1941 г. «О предоставлении амнистии польским гражданам, содержащимся в заключении на территории СССР»: Русский архив: Великая Отечественная. СССР и Польша: 1941-1945. М.: ТЕРРА, 1994. Т. 14 (3-1). С. 24.

Упадышев Н.В. ГУЛАГ на Европейском Севере: генезис, эволюция, распад. Архангельск: Поморский государственный университет, 2007. 323 с.

Хлевнюк О.В. Большой террор 1937-1938 гг. как проблема научной историографии // Историческая наука и образование на рубеже веков. М.: Собрание, 2004. С. 433-451.

Цветков С.Н. О настроениях граждан СССР немецкой национальности, вернувшихся изза границы на жительство в Вологодскую область после Великой Отечественной войны // Воинский подвиг защитников Отечества: традиции, преемственность, новации: материалы межрегиональной научно-практической конференции. Ч. 3. Вологда: Наука, 2000. С. 200207.

Чебыкина T. Депортация немецкого населения из европейской части СССР в Западную Сибирь (1941-1945 гг.) // Репрессии против советских немцев. Наказанный народ. М.: Звенья, 1999. С. 118-127. 
Шашков В.Я. Раскулачивание в СССР и судьбы спецпереселенцев (1930-1954 гг.): дис. ... д-ра ист. наук. Московский государственный университет им. М.В. Ломоносова, 1995. $427 \mathrm{c}$.

Шашков В.Я. Репрессии в СССР против крестьян и судьбы спецпереселенцев КарелоМурманского края. Мурманск: Мурманский государственный педагогический институт, 2000. $341 \mathrm{c}$.

Шашков В.Я. Спецпереселенцы на Мурмане. Роль спецпереселенцев в развитии производительных сил на Кольском полуострове (1930-1936 гг.). Мурманск: Мурманский государственный педагогический институт, 1993. 139 с.

Шашков В.Я., Козлов С.С., Лобченко Л.Н. ГУЛАГовская система спецпереселений Северного края для «бывших кулаков». Мурманск: Мурманский государственный педагогический институт, 2008. 245 с.

Шевяков А.А. «Тайны» послевоенной репатриации // Социологические исследования. 1993. № 8. С. 3-12.

Шевяков А.А. Гитлеровский геноцид и репатриация советского населения // Людские потери СССР в период Второй мировой войны: сборник статей. СПб.: Русско-Балтийский информационный центр «Блиц», 1995. С. 178-181.

Шевяков А.А. Репатриация советского мирного населения и военнопленных, оказавшихся в оккупационных зонах государств антигитлеровской коалиции // Население России в 1920-1950-е годы: численность, потери, миграции: сборник научных трудов. М.: Институт российской истории, 1994. С. 195-222.

Dahlmann D. «Operation erfolgreich durchgeführt». Die Deportationen der Wolgadeutschen 1941 // Flucht und Vertreibung: zwischen Aufrechnung und Verdraengung. Wien: Picus-Verlag, 1994. S. 201-226.

Eisfeld A., Herdt V. Deportation, Sondersiedlung, Arbeitsarmee: Deutsche in der Sowjetunion 1941 bis 1956. Köln: Wissenschaft und Politik, 1996. 555 s.

Gurjanow A. Cztery deportacje 1940-1941 // KARTA: Niezależne pismo historyczne (Warszawa). 1994. Nr 12. S. 114-136. [Гурьянов А. Четыре депортации 1940-1941 гг. // Независимый исторический журнал. Варшава: Центр КАРТА, 1994. № 12. С 114-136.]

Martin T. The Origin of Soviet Ethnic Cleansing // The Journal of Modern History. December, 1998. Vol. 70. № 4. P. 812-861.

Merl S. Das System der Zwangsarbeit und die Opferzahl im Stalinismus // Geschichte im Wissenschaft und Unterricht. 1995. Jg. 46. Heft 5/6. S. 277-301.

Pohl J.O. The Stalinist Penal System. A Statistical History of Soviet Repression and Terror, 1930-1953. Jefferson, NC; London: McFarland \& Company, Inc., Publishes, 1997. 165 p.

\section{References}

Adibekov, G.M. "Spetspereselentsy - zhertvy 'sploshnoi-kollektivizatsii'. Iz dokumentov 'osoboi papki' politbyuro TsK VKP(b). 1930-1932 gg." [Special settlers, the victims of 'wholesale collectivization.' From the documents in the 'special folder' of the Politburo of the Central Committee of VKP(b) 1930-1932], Istoricheskii arkhiv, no. 4 (1994): 145-80. (In Russian)

Artemova, O.V. "Spetspereselentsy v Vozhegodskom raione (1930e gody)" [Special settlers in Vozhega district (the 1930s)]. In Vozhega: kraevedcheskii al'manakh [Vozhega: an almanac of regional studies], 195-220. Vologda: Rus', 1995. (In Russian)

Belkovets, L.P. Administrativno-pravovoe polozhenie rossiiskikh nemtsev na spetsposelenii, 1941-1955 gg.: istoriko-pravovoe issledovanie [Administrative and legal status of Russian Ger- 
mans in special settlement, 1941-1955: historical and legal study]. Moscow: ROSSPEN, 2008. 359 p. (In Russian)

Belov, V.T., O.I. Korytova, and V.S. Tsyvarev, eds. Pomorskii memorial: Kniga pamyati zhertv politicheskikh repressii [Pomor memorial. Book of memory of the victims of political repression]. Vol. 1. Arkhangelsk: Pomorskii gosudarstvennyi universitet, 1999. 869 p. (In Russian)

Berdinskikh, V.A. Spetsposelentsy. Politicheskaya ssylka narodov Sovetskoi Rossii [Special settlers. Political exile of peoples of Soviet Russia]. Kirov: Kirovskaya oblastnaya tipografiya, 2003. 527 p. (In Russian)

Berdinskikh, V.A., I.V. Berdinskikh, and I.V. Verem'ev. Sistema spetsposelenii v Sovetskom Soyuze 1930-1950-kh godov [The system of special settlements in the Soviet Union in the 1930s1950s]. Moscow: ROSSPEN, 2017. 503 p. (In Russian)

Beznin, M.A., ed., Dovereno okhranyat' Otechestvo. (Iz istorii organov bezopasnosti v Vologodskom krae) [Entrusted with protection of the Fatherland. (From the history of security organs in Vologda region)]. Vologda: Vologodskii gosudarstvennyi pedagogicheskii universitet, 2008. 581 p. (In Russian)

Bugai, N.F. Deportatsiya narodov Kryma: dokumenty, fakty, kommentarii [Deportations of Crimean peoples: documents, facts, commentary]. Moscow: INSAN, 2002. 240 p. (In Russian)

Bugai, N.F. Iosif Stalin - Lavrentiyu Berii: "Ikh nado deportirovat'...": dokumenty, fakty kommentarii [Joseph Stalin - Lavrenti Beria: "They are to be deported": documents, facts, commentary]. Moscow: Druzhba narodov, 1992. 288 p. (In Russian)

Bugai, N.F. L. Beriya - I. Stalinu: "Soglasno Vashemu ukazaniyu... ”: [O deportatsii narodov v SSSR v 30-40-e gg.] [L. Beria - J. Stalin: "According to your orders": on deportation of peoples in the USSR in 1930s-1940s]. Moscow: AIRO-XX, 1995. 320 p. (In Russian)

Bugai, N.F. "Mobilizovat' nemtsev v rabochie kolonny... I. Stalin": sbornik dokumentov (1940-e gody) [“Mobilize Germans into labor columns... J. Stalin”: collection of documents, 1940s]. Moscow: Gotika, 1998. 350 p. (In Russian)

Bugai, N.F., and A.V. Gonov. Kavkaz: narody v eshelonakh (20-60-e gody) [Caucasus: peoples in special trains (20s-60s)]. Moscow: INSAN, 1998. 368 p. (In Russian)

Chebykina, T. "Deportatsiya nemetskogo naseleniya iz evropeiskoi chasti SSSR v Zapadnuyu Sibir' (1941-1945 gg.)" [Deportation of German population from the European USSR to Western Siberia, 1941-1945]. In Repressii protiv sovetskikh nemtsev. Nakazannyi narod [Repression against Soviet Germans. A punished people], 118-27. Moscow: Zven'ya, 1999. (In Russian)

Dahlmann D. "Operation erfolgreich durchgeführt". Die Deportationen der Wolgadeutschen 1941". In Flucht und Vertreibung: zwischen Aufrechnung und Verdraengung, 201-26. Vienna: Picus-Verlag, 1994.

Danilov, V.P., and S.A. Krasil'nikov, eds. Spetspereselentsy v Zapadnoi Sibiri, vesna 1931 nach. 1933 g.: sbornik dokumentov [Special settlers in Western Siberia, spring 1931 - beginning 1933: a collection of documents]. Novosibirsk: EKOR, 1993. 341 p. (In Russian)

Dashchinskii, S.N., V.V. Voronin, and V.A. Nechushkin, eds. Kniga pamyati: Rossiiskaya Federatsiya, Murmanskaya oblast'. Poimennyi spisok repressirovannykh zhitelei Kol'skogo poluostrova, a takzhe inostrannykh grazhdan, prozhivavshikh v Murmanskoi oblasti [Book of memory. Russian Federation. Murmansk Region. Nominal list of the Kola Peninsula residents who were the victims of repression and foreign citizens who resided in Murmansk Region]. Murmansk: Sever, 1997. 412 p. (In Russian)

Dobronozhenko, G.F. Kollektivizatsiya na Severe. 1929-1932 gg. [Collectivization in the North. 1929-1932]. Syktyvkar: Syktyvkarskii universitet, 1994. 194 p. (In Russian) 
Dobronozhenko, G.F. "Provedenie sploshnoi kollektivizatsii v Severnom krae (19291932 gg.)" [Conducting wholesale collectivization in the Northern Krai (1929-1932)]. PhD diss. Pertozavodsk, 1993 (In Russian).

Dobronozhenko, G.F., and L.S. Shabalova. "Kulatskaya ssylka v Komi oblasti v pervoi polovine 1930-kh godov" [Kulak exile in Komi Oblast in the first half of 1930s]. In Pokayanie: martirolog [Penance: martyrology], vol. 4, part 1, 15-123. Syktyvkar: Komi knizhnoe izdatel'stvo, 2001. (In Russian)

Drazdovich, L.I., A.Yu. Zhukov, V.G. Makurov, O.A. Nikitina, and A.T. Filatova, eds. Iz istorii raskulachivaniya $v$ Karelii, 1930-1931 gg.: dokumenty $i$ materialy [From the history of dekulakization in Karelia, 1930-1931: documents and materials]. Petrozavodsk: Kareliya, 1991. 295 p. (In Russian)

Dzenkevich, A., E. Rybarska, A. Gur'yanov, A. Rachinskii, and S. Starostin, eds. Pol'skie spetspereselentsy v Vologodskoi oblasti. Alfavitnye spiski 14226 pol'skikh grazhdan, vyslannykh $v$ 1940 g. iz zapadnykh oblastei BSSR $i$ USSR [Polish special resettlers in Vologda Oblast. Alphabetical list of 14226 Polish citizens deported from the western oblasts of the Belorussian SSR and Ukrainian SSR]. Indeks Repressirovannykh. Vyp. XVII [Index of repression victims. Issue 17]. Warsaw: Centr KARTA, 2005. 703 p. (In Russian)

Eisfeld, A., and V. Herdt. Deportation, Sondersiedlung, Arbeitsarmee: Deutsche in der Sowjetunion 1941 bis 1956. Köln: Wissenschaft und Politik, 1996. 555 S.

Gintsberg, L.I. "Massovye deportatsii krest'yan v 1930-1931 godakh i usloviya ikh sushchestvovaniya v Severnykh krayakh (po materialam 'osobykh papok' politbyuro TsK VKP(b) i 'komissii Andreeva"'[Mass deportations of peasants in 1930-1931 and the history of their existence in the Northern Regions (based on the materials in 'special folders' of the Pulitburo of the Central Committee of $\operatorname{VKP}(\mathrm{b})$ and the 'Andreev Commission'], Otechestvennaya istoriya, no. 2 (1998): 190-96. (In Russian)

Gintsberg, L.I. "Po stranitsam 'osobykh papok' politbyuro TsK VKP(b) [Following the pages of the "special folders" of the Politburo of the Central Committee of VKP(b)], Voprosy istorii, no. 8 (1996): 16-30. (In Russian)

Gurjanow, A. "Chetyre deportatsii 1940-1941 gg.", Nezavisimyi istoricheskii zhurnal, no. 12 (1994): 114-36. (in Polish)

Gur'yanov, A.E. "Masshtaby deportatsii naseleniya v glub' SSSR v mae-iyune 1941 g." [The scale of the deportation of population inland the USSR in May-June 1941]. In Repressii protiv polyakov i pol'skikh grazhdan [Repression against ethnic Poles and Polish citizens], comp. by A.E. Gur'yanov, 137-75. Moscow: Zven'ya, 1997. (In Russian)

Gur'yanov, A.E. "Pol'skie spetspereselentsy v Sibiri (1940-1941)" [Polish special settlers in Siberia (1940-1941)]. In Sibir'v istorii i kul'ture pol'skogo naroda [Siberia in history and culture of Polish people], compiled by A. Kuchinskii, and P.S. Romanov, 368-75. Moscow: Ladomir, 2002. (In Russian)

Gur'yanov, A.E. "Pol'skie spetspereselentsy v SSSR v 1940-1941 gg." [Polish special settlers in the USSR in 1940-1941]. In Repressii protiv polyakov i pol'skikh grazhdan [Repression against ethnic Poles and Polish citizens], compiled by A.E. Gur'yanov, 114-36. Moscow: Zven'ya, 1997. (In Russian)

Gur'yanov, A.E. "Vvedenie" [Introduction]. In Polskiye spetspereselentsy v Arkhangelskoy oblasti. Chast. 1. [Polish special resettlers in Arkhangelsk Oblast. Part 1]. Indeks repressirovannykh. Vyp. XIV. [Index of the victims of repression. Issue 14], E. Rybarsk, A. Gur'yanov, A. Rachinsky and T. Lozinskaya, eds. 754-810. Warsaw, 2003. (In Russian) 
Ignatova, N.M. "Periodizatsiya protsessa spetspereseleniya v Respublike Komi” [Periodization of the process of special resettlement]. In Aktual'nye problemy kraevedeniya Respubliki Komi: tezisy dokladov [Pressing issues of Komi Republic local studies: abstracts], edited by M.A. Matsuk, 32-33. Syktyvkar: Obshchestvo izucheniya Komi kraya; Ministerstvo po delam natsional'nostei Respubliki Komi, 1997. (In Russian)

Ignatova, N.M. "Prinuditel'nyi trud spetspereselentsev kak sistemnyi faktor industrial'nogo osvoeniya severnykh regionov v 1930-1950 gg." [Forced labor of special settlers as a systematic factor for industrial reclamation of the northern regions in 1930s-1950s]. In Istoriya stalinizma: Prinuditel'nyi trud v SSSR. Ekonomika, politika, pamyat': materialy mezhdunarodnoi nauchnoi konferentsii. Moskva, 28-29 oktyabrya 2011 g. [History of Stalinism: Forced labor in the USSR. Economics, policies, memory: proceedings of the international scientific conference. Moscow, 2829 October, 2011], edited by L.I. Borodkin, S.A. Krasil'nikov, and O.V. Khlevnyuk, 433-49. Moscow: ROSSPEN, 2013. (In Russian)

Ignatova, N.M. "Prizyv trudpereselentsev v SSSR na front v 1942 g." [Conscripting labor settlers of the USSR to the front in 1942], Voprosy istorii, no. 11, (2013): 97-103. (In Russian)

Ignatova, N.M. "Smertnost' spetspereselentsev v Severnom krae v 1930-e gg.: prichiny, masshtab, statisticheskii uchet" [Mortality rate of special settlers in the Northern Krai in the 1930s: causes, scale, statistical records], The New Historical Bulletin, no. 2 (28), (2011): 42-52. (In Russian)

Ignatova, N.M. "Sotsial'nyi protest spetspereselentsev v Arkhangel'skoi oblasti i Respublike Komi v 1941-1945 gg." [Social protest of special settlers in Arkhangelsk Region and Komi Republic in 1941-1945]. In Zashchitniki Otechestva: materialy XV regional'nykh obshchestvennonauchnykh chtenii po voenno-istoricheskoi tematike [Defenders of the Fatherland: proceedings of the $15^{\text {th }}$ regional social science readings in military history], 148-56. Arkhangelsk: Pravda Severa, 2004. (In Russian)

Ignatova, N.M. "Sotsial'nyi protest spetspereselentsev v Severnom krae v 1930-1936 gg." [Social protest of special settlers in the Northern Krai in 1930-1936]. In Dvinskaya zemlya: materialy mezhregional'nykh obshchestvenno-nauchnykh istoriko-kraevedcheskikh Stefanovskikh chtenii. [Dvina land: proceedings of interregional Stephen of Perm readings in social sciences and local history], 81-89. Kotlas: Pravda Severa, 2002. (In Russian)

Ignatova, N.M. "Spetspereselentsy v Respublike Komi v 1930-1940-e gg.: zaselenie i usloviya zhizni" [Special settlers in Komi Republic in 1930s-1940s: settlement and living conditions]. In Korni travy: sbornik statei molodykh istorikov, pod red. L.S. Ereminoi, E.B. Zhemkovoi [Roots of the grass: a collection of papers by young historians], eds. by L.S. Eremina, E.B. Zhemkova, 23-35. Moscow: Zven'ya, 1996. (In Russian)

Ignatova, N.M. Spetspereselentsy v Respublike Komi v 1930-1950-e gody [Special settlers in Komi Republic in 1930s-1950s]. Syktyvkar: Komi nauchnyi tsentr Instituta yazyka, literatury i istorii, 2009. 192 p. (In Russian)

Ivnitskii N.A., ed. Kollektivizatsiya sel'skogo khozyaistva v Severo-Zapadnom raione (19271937 gg.) [Collectivization of agriculture in the North-Western area (1927-1937): collection of documents], comps. V.A. Seleznev, and A.Ya. Starikova. Leningrad, 1970. 424 p. (In Russian)

Ivnitskii, N.A. Kollektivizatsiya i raskulachivanie: nachalo 30-kh godov [Collectivization and dekulakization. The early 1930s]. Moscow: Interpraks, 1994. 267 p. (In Russian)

Ivnitskii, N.A. Repressivnaya politika sovetskoi vlasti v derevne (1928-1933) [Repressive policy of Soviet rule in the countryside (1928-1933)]. Moscow: Institut rossiiskoi istorii RAN, 2000. 350 p. (In Russian) 
Ivnitskii, N.A. Sud'ba raskulachennykh $v$ SSSR [The fate of dispossessed kulaks in the USSR]. Moscow: Sobranie, 2004. 296 p. (In Russian)

Khlevnyuk, O.V. "Bol'shoi terror 1937-1938 gg. kak problema nauchnoi istoriografii" [The great terror of 1937-1938 as a problem of scientific historiography]. In Istoricheskaya nauka $i$ obrazovanie na rubezhe vekov [Historical science and education at the turn of the century], 433-51. Moscow: Sobranie, 2004. (In Russian)

Kokurin, A.I. "Spetspereselentsy v SSSR v 1944 godu, ili God bol'shogo pereseleniya" [Special settlers in the USSR in 1945, or the Year of great resettlement], Otechestvennye arkhivy, no. 5 (1993): 102-10. (In Russian)

Kokurin, A.I., and N.V. Petrov. "GULAG: struktura i kadry" [GULAG: structure and personnel], Svobodnaya mysl'- XXI, no. 8 (1999): 109-28. (In Russian)

Kokurin, A.I., and N.V. Petrov. “OGPU (1929-1934)", Svobodnaya mysl'- XXI, no. 8 (1998): 95-114. (In Russian)

Kollektivizatsiya sel'skogo khozyaistva v Severnom raione (1927-1937 gg.): sbornik dokumentov [Collectivization of agriculture in the Northern area (1927-1937): a collection of documents]. Vologda: Severo-Zapadnoe knizhnoe izdatel'stvo, 1964. 696 p. (In Russian)

Konasov, V.B., and V.V. Sudakov. Ekho minuvshei voiny: iz istorii Vologodskoi oblasti [Echo of the past war: from the history of Vologda Region]. Vologda: Institut povysheniya kvalifikatsii i professional'noi perepodgotovki kadrov, 1994. 89 p. (in Russina)

Krasil'nikov, S.A. Serp i molokh. Krest'yanskaya ssylka v Zapadnoi Sibiri v 1930-e gody [Sickle and moloch. Peasant exile in Western Siberia in 1930s]. Moscow: ROSSPEN, 2003. 288 p. (In Russian)

Krasil'nikov, S.A., M.S. Salamatova, and S.N. Ushakova. Korni i shchepki. Krest'yanskaya sem'ya na spetsposelenii v Zapadnoi Sibiri v 1930-kh - nachale 1950-kh gg [Roots and chips. A peasant household in special settlement in Western Siberia in 1930s - early 1950s]. Moscow: ROSSPEN, 2010. 326 p. (In Russian)

Kulagina, V.S., and V.A. Shchepakov, eds. Sbornik zakonodatel'nykh i normativnykh aktovo repressiyakh $i$ reabilitatsii zhertv politicheskikh repressii [A collection of legislative and statutory acts on repression and rehabilitation of the victims of political repression]. Part 1. Edited by G.F. Vesnovskaya. Kursk: GUIPP "Kursk”, 1999. 510 p. (In Russian)

Kurochkin, A.N. "Trudarmeiskie formirovaniya iz grazhdan SSSR nemetskoi natsional'nosti v gody Velikoi Otechestvennoi voiny (1941-1945 gg.)" [Labor Army units formed from the USSR citizens of German ethnicity during the years of the Great Patriotic War (1941-1945)]. PhD thesis. Saratov Higher Military School of Rocket Forces, 1998 (In Russian).

Kuzminykh, A.L., and S.I. Starostin. "Pol'skie voennoplennye i spetspereselentsy v Vologodskoi oblasti (1939-1941 gg.)" [Polish prisoners of war and special settlers in Vologda Region (1939-1941)]. In Rossiya - Pol'sha: filologicheskii i istoriko-kul'turnyi diskurs: sbornik statei uchastnikov Mezhdunarodnoi nauchnoi konferentsii (Magnitogorsk, 18-19 noyabrya 2005 g.), otv. red.-sost. S.T. Shulezhkova [Russia - Poland: philological and historical and cultural discourse: collected papers of the participants of the international scientific conference (Magnitogorsk, 18-19 November 2005], ed. by S.T. Shulezhkova, 104-11. Magnitogorsk: Magnitogorskii gosudarstvennyi universitet, 2005. (In Russian)

Kuzminykh, A.L., and S.I. Starostin. Polyaki v Vologodskoi oblasti: repressii, plen, spetsposelenie (1937-1953 gg.)[Poles in Vologda Oblast: repression, captivity, special settlement (1937-1953)]. Vologda: Drevnosti Severa, 2014. 688 p. (In Russian) 
Pikhoya, R.G., and A. Geishtor, eds. Katyn': plenniki neob"yavlennoi voiny: dokumenty $i$ materialy [Katyn: prisoners of undeclared war: documents and materials]. Moscow: Demokratiya, 1999. 608 p. (In Russian)

Lesnaya promyshlennost' Komi ASSR: sbornik dokumentov, 1917-1960 [Timber industry of Komi ASSR: a collection of documents, 1917-1960]. Syktyvkar: Komi knizhnoe izdatel'stvo, 1989. 294 p. (In Russian)

Martin, T. "The Origin of Soviet Ethnic Cleansing”, The Journal of Modern History, vol. 70, no. 4 (1998): 812-61.

Merl, S. "Das System der Zwangsarbeit und die Opferzahl im Stalinismus", Geschichte im Wissenschaft und Unterricht, Jg. 46. Heft 5/6 (1995): 277-301.

Nikitina, O.A. "Kollektivizatsiya $i$ raskulachivanie $v$ Karelii" [Collectivization and dekulakization in Karelia]. PhD thesis, Institute of Russian History of Russian Academy of Sciences, 1993 (In Russian).

Okhotin, N., and A. Roginskii. "Iz istorii 'nemetskoi operatsii' NKVD 1937-1938 gg.” [From the history of the German operation of the NKVD in 1937-1938]. In Repressii protiv rossiiskikh nemtsev. Nakazannyi narod [Repression against Russian Germans. A punished people], 35-74. Moscow: Zven'ya, 1999. (In Russian)

Perepechenko, P.K., and G.I. Sokolov, eds. Vologzhane - Geroi Sovetskogo Soyuza: sbornik [Citizens of Vologda - Heroes of the Soviet Union: collection of articles]. Vologda: SeveroZapadnoe knizhnoe izdatel'stvo, 1970. 432 p. (In Russian)

Pikhoya, R.G., ed. Lubyanka. VChK-OGPU-NKVD-NKGB-MGB-MVD-KGB. 1917-1960: spravochnik [Lubyanka. VChK-OGPU-NKVD-NKGB-MGB-MVD-KGB. 1917-1960: reference book], comps. A.I. Kokurin, and N.V. Petrov. Moscow: MFD, 1997. 352 p. (In Russian)

Pohl, J. Otto. The Stalinist Penal System. A Statistical History of Soviet Repression and Terror, 1930-1953. Jefferson, NC: McFarland, 1997. 165 p.

Pokrovskii, N.N., ed. Politbyuro i krest'yanstvo: vysylka, spetsposelenie. 1930-1940. [Politburo and peasantry: exile, special settlement. 1930-1940]. Book 1. Moscow: ROSSPEN, 2005. 912 p. (In Russian)

Pokrovskii, N.N., V.P. Danilov, S.A. Krasil'nikov, and L. Viola, eds. Politbyuro $i$ krest'yanstvo: vysylka, spetsposelenie. 1930-1940. [Politburo and peasantry: exile, special settlement. 1930-1940]. Book 2. Moscow: ROSSPEN, 2006. 1120 p. (In Russian)

Polian, P.M. Ne po svoei vole...: Istoriya i geografiya prinuditel'nykh migratsii $v$ SSSR [Against their will: the history and geography of forced migrations in the USSR]. Moscow: OGIMemorial, 2001. 328 p. (In Russian)

Rogachev, M.B. "Deportatsiya pol'skikh grazhdan v Komi ASSR (1940-1941 gg.)" [Deportation of Polish citizens to Komi ASSR. 1940-1941]. In Polyaki v Rossii: istoriya ssylki $i$ deportatsii: tezisy dokladov i materialy [Poles in Russia: history of exile and deportation: abstracts and materials], 31-46. St. Petersburg, 1995. (In Russian)

Rogachev, M.B. "Stranitsy pol'skoi tragedii: fakty i dokumenty" [Pages of Polish tragedy: facts and documents]. In Pokayanie: martirolog [Penance: martyrology], comp. by M.B. Rogachev, vol. 5, 14-463. Syktyvkar: Komi knizhnoe izdatel'stvo, 2002. (In Russian)

Shashkov, V.Ya. "Raskulachivanie v SSSR i sud'by spetspereselentsev (1930-1954 gg.)" [Dekulakization in the USSR and the fate of special settlers (1930-1954)]. Doctorate diss. Lomonosov Moscow State University, 1995 (In Russian).

Shashkov, V.Ya. Repressii v SSSR protiv krest'yan $i$ sud'by spetspereselentsev KareloMurmanskogo kraya [Repression against peasants in the USSR and the fate of special settlers in 
Karelia and Murmansk regions]. Murmansk: Murmanskii gosudarstvennyi pedagogicheskii institut, 2000. 341 p. (In Russian)

Shashkov, V.Ya. Spetspereselentsy na Murmane. Rol' spetspereselentsev $v$ razvitii proizvoditel'nykh sil na Kol'skom poluostrove (1930-1936 gg.) [Special settlers in Murman. The role of special settlers in the development of productive forces in the Kola Peninsula. 1930-1936]. Murmansk: Murmanskii gosudarstvennyi pedagogicheskii institut, 1993. 139 p. (In Russian)

Shashkov, V.Ya., S.S. Kozlov, and L.N. Lobchenko. GULAGovskaya sistema spetspereselenii Severnogo kraya dlya "byvshikh kulakov". [The GULAG system of the Northern Krai special settlements for the "former kulaks"]. Murmansk: Murmanskii gosudarstvennyi pedagogicheskii institut, 2008. 245 p. (In Russian)

Shevyakov, A.A. "Gitlerovskii genotsid i repatriatsiya sovetskogo naseleniya" [Hitler's genocide and repatriation of Soviet population]. In Lyudskie poteri SSSR v period Vtoroi mirovoi voiny: sbornik statei [Human losses of the USSR in the period of the Second World War: a collection of articles], 178-81. St. Petersburg: Russko-Baltiiskii informatsionnyi tsentr "Blits", 1995. (In Russian)

Shevyakov, A.A. "Repatriatsiya sovetskogo mirnogo naseleniya i voennoplennykh, okazavshikhsya v okkupatsionnykh zonakh gosudarstv antigitlerovskoi koalitsii" [Repatriation of Soviet civilian population and prisoners of war from the zones of occupation of Anti-Hitler Coalition states]. In Naselenie Rossii v 1920-1950-e gody: chislennost', poteri, migratsii: sbornik nauchnykh trudov [Population of Russia in 1920s-1950s: numbers, losses, migrations: a collection of research papers], 195-222. Moscow: Institut rossiiskoi istorii RAN, 1994. (In Russian).

Shevyakov, A.A. "Tainy' poslevoennoi repatriatsii" [The mysteries of the post-war repatriation], Sotsiologicheskie issledovaniya, no. 8 (1993): 3-12.

Smirnov, M.B., ed. Sistema ispravitel'no-trudovykh lagerei v SSSR. 1923-1960: spravochnik [The system of corrective labor camps in the USSR. 1923-1960: a reference book]. Moscow: Zven'ya, 1998. 597 p. (In Russian)

Starostin, S.I. "Deportirovannye sovetskie i inostrannye grazhdane v gody Velikoi Otechestvennoi voiny (na materialakh Arkhangel'skoi i Vologodskoi oblastei)" [Deported Soviet and foreign citizens during the years of the Great Patriotic War (case study of Archangelsk Region and Vologda Region)]. In 1941-1945: uroki voiny - uroki pravdy, muzhestva i patriotizma: materialy mezhregional'noi nauchno-prakticheskoi konferentsii (g. Vologda, 24-25 fevralya 2005 g.) [1941-1945: history lessons are the lessons of truth, courage and patriotism: proceedings of the international scientific conference (Vologda, 24-25 February 2005)], 101-12. Vologda: Rus', 2006. (In Russian)

Starostin, S.I. "Dokumenty arkhiva UVD Vologodskoi oblasti o sud'bakh deportirovannykh grazhdan SSSR i drugikh stran" [Documents from the archive of Vologda Region Internal Affairs Administration about the fate of the deported citizens of the USSR and other countries]. In Istoricheskoe kraevedenie i arkhivy: materialy mezhregional'noi nauchnoi konferentsii. Vyp. 10, pod red. A.V. Kamkina, O.A. Naumovoi [Historical local studies and archives: proceedings of the interregional scientific conference. Issue 10], eds. by A.V. Kamkin, O.A. Naumova, 184-96. Vologda: Poligrafist, 2004. (In Russian)

Starostin, S.I. "Istoriya sovetskoi ssylki na Evropeiskom Severe: 1930-1956 gg. (na materialakh arkhivov Vologodskoi oblasti)" [The history of Soviet exile in the European North: 1930-1956]. In Istoriya i perspektivy ugolovno-ispolnitel'noi sistemy Rossii: sbornik materialov nauchno-prakticheskogo seminara (Vologda, 4 aprelya 2002 g.) [History and prospects of Russian penitentiary system: proceedings of the scientific and practical seminar (Vologda, 4 April 2002)], 98-106. Vologda: Vologodskii institut prava i ekonomiki Minyusta Rossii, 2002. (In Russian) 
Starostin, S.I. "Pereselenie polyakov iz Vologodskoi oblasti (1944 god)" [Resettling Poles from Vologda Region. 1944]. In Istoricheskoe kraevedenie $i$ arkhivy: materialy oblastnoi nauchnoprakticheskoi konferentsii. Vyp. 17, pod red. A.V. Kamkina, O.A. Naumovoi [Historical local studies and archives: proceedings of the regional scientific and practical conference. Issue 17], eds. by A.V. Kamkin, O.A. Naumova, 138-45. Vologda: Poligrafist, 2010. (In Russian)

Starostin, S.I. "Struktura i funktsii administratsii spetspereselencheskikh poselkov Vologodskoi oblasti v 1930-1956 gody" [Structure and functions of the administration of the special settlements in Vologda Ovlast in 1930-1956]. In Istoricheskoe kraevedenie i arkhivy: sbornik statei. Vyp. 9, pod red. A.V. Kamkina, O.A. Naumovoi [Historical local studies and archives: a collection of articles. Issue 9], eds. by A.V. Kamkin, O.A. Naumova, 109-25. Vologda: Poligrafist, 2003. (In Russian)

Starostin, S.I. "Tragicheskie stranitsy istorii. Tochka eshche ne postavlena..." [Tragic pages in history. The $i$ 's haven't been dotted yet], In Istoricheskoe kraevedenie $i$ arkhivy: materialy $V i$ VI nauchno-prakticheskikh konferentsii. Vyp. 5 [Historical local studies and archives: proceedings of $5^{\text {th }}$ and $6^{\text {th }}$ scientific and practical conferences. Issue 5], 67-76. Vologda: Poligrafist, 1999. (In Russian)

Suslov, A.B. Spetskontingent v Permskoi oblasti (1929-1953 gg.) [Special contingent in Perm Oblast (1929-1953)]. Moscow: ROSSPEN, 2010. 424 p. (In Russian)

Tragediya sovetskoi derevni. 1927-1939 [Tragedy of the Soviet village. 1927-1939], vol. 2. November, 1929 - December, 1930. Moscow: ROSSPEN, 2000, 927. (In Russian)

Tsarevskaya, T.V., ed. Istoriya stalinskogo GULAGa [History of Stalin's GULAG]. Vol. 5, Spetspereselentsy $v$ SSSR [Special settlers in the USSR]. Moscow: ROSSPEN, 2004. 824 p. (In Russian)

Tsvetkov, S.N. "O nastroeniyakh grazhdan SSSR nemetskoi natsional'nosti, vernuvshikhsya izza granitsy na zhitel'stvo v Vologodskuyu oblast' posle Velikoi Otechestvennoi voiny" [On the attitudes of the USSR citizens of German ethnicity who returned from abroad to reside in Vologda Oblast after the Great Patriotic War]. In Voinskii podvig zashchitnikov Otechestva: traditsii, preemstvennost', novatsii: materialy mezhregional'noi nauchno-prakticheskoi konferentsii [Feat of arms of the defenders of the Fartherland: tradition, continuity, innovation. Proceedings of the interregional scientific and practical conference], part 3, 200-07. Vologda: Nauka, 2000. (In Russian)

Ukaz PVS SSSR ot 12.08 .1941 g. "O predostavlenii amnistii pol'skim grazhdanam, soderzhashchimsya $v$ zaklyuchenii na territorii SSSR»: Russkii arkhiv: Velikaya Otechestvennaya. SSSR $i$ Pol'sha: 1941-1945 [Decree of the Presidium of the Supreme Soviet of the USSR dated 12.08.1941 "On granting amnesty to the Polish citizens held in state custody on the territory of the USSR": Russian archive: The Great Patriotic War. USSR and Poland: 1941-1945], vol. 14 (3-1), 24. Moskow: TERRA, 1994. (In Russian)

Upadyshev, N.V. GULAG na Evropeiskom Severe: genezis, evolyutsiya, raspad [GULAG in the European North: genesis, evolution, decline]. Arkhangelsk: Pomorskii gosudarstvennyi universitet, 2007. 323 p. (In Russian)

Vashkau, N.E. "Rossiiskie nemtsy v 'trudovoi armii': vklad v Pobedu" [Russian Germans in 'Labor Army': contribution to the Victory]. In Voinskii podvig zashchitnikov Otechestva: traditsii, preemstvennost', novatsii. Materialy mezhregional'noi nauchno-prakticheskoi konferentsii. Ch. 3, pod red. V.V. Sudakova, V.B. Konasova [Feat of arms of the defenders of the Fartherland: tradition, continuity, innovation. Proceedings of the interregional scientific and practical conference. Part 3], eds. by V.V. Sudakov, V.B. Konasov, 200-07. Vologda: Vologodskii institut razvitiya obrazovaniya, 2000. (In Russian) 
Vashkau, N.E. "Zhenshchina v trudarmii” [A woman in the Labor Army]. In Problemy istorii Vtoroi mirovoi voiny. Sbornik nauchnykh rabot, pod red. V.V. Sudakova, B.V. Petelina, S.A. Tikhomirova, S.N. Tsvetkova [Problems of the history of the Second World War: a collection of research papers], eds. by V.V. Sudakov, B.V. Petelin, S.A. Tikhomirov, S.N. Tsvetkov, 82-98. Vologda: Vologodskii gosudarstvennyi universitet, 2000. (In Russian)

Vavulinskaya, L.I. Spetspereselentsy $i$ inostrannye voyennoplennye v Karelii v seredine 1940$\mathrm{kh}$ - seredine 1950-kh gg. [Special settlers and foreign prisoners of war in Karelia in the mid-1940s - mid-1950s]. Petrozavodsk: Karel'skii nauchnyi tsentr RAN, 2013. 337 p. (In Russian)

Viola, Lynne. Krest'yanskii GULAG: mir stalinskikh spetsposelenii [The Unknown Gulag. The Lost World of Stalin's Special Settlements]. Moscow: ROSSPEN, 2010. 335 p. (In Russian)

Yakovlev, A.N., ed. GULAG: Glavnoe upravlenie lagerei. 1918-1960 [GULAG: Main Administration of Camps. 1918-1960], comps. A.L. Kokurin and N.V. Petrov. Moscow: MFD, 2000. 888 p. (In Russian)

Yakovlev, A.N., ed. Stalinskie deportatsii. 1928-1953 [Stalin's deportations. 1928-1953]. comps. N.L. Pobol', and P.M. Polyan,. Moscow: MFD: Materik, 2005. 904 p. (In Russian)

Zaitsev, E.A., ed. Sbornik zakonodatel'nykh i normativnykh aktov o repressiyakh i reabilitatsii zhertv politicheskikh repressii [Collection of legislative and regulatory acts relative to the persecution and rehabilitation of the victims of political repression]. Moscow: Respublika, 1993. 222 p. (In Russian)

Zemskov, V.N. "Deportatsiya naseleniya. Spetsposelentsy i ssyl'nye. Zaklyuchennye” [Deportation of population. Special settlers and exiles. Prisoners]. In Naselenie Rossii v XX veke [Population of Russia in the $20^{\text {th }}$ century], edited by Yu.A. Polyakov, vol. 2, 166-96. Moscow: ROSSPEN, 2000. (In Russian)

Zemskov, V.N. 'Kulatskaya ssylka' v 1930-e gody: chislennost', rasselenie, sostav" [Kulak exile in 1930s: numbers, settlement, composition]. In Naselenie Rossii $v$ XX veke [Population of Russia in the $20^{\text {th }}$ century], edited by Yu.A. Polyakov, vol. 1, 277-310. Moscow: ROSSPEN, 2000. (In Russian)

Zemskov, V.N. Spetsposelentsy v SSSR, 1930-1960 [Special Settlers in the USSR, 1930-1960]. Moscow: Nauka, 2005. 306 p. (In Russian)

Zemskov, V.N. "Sud'ba 'kulatskoi ssylki' (1930-1954 gg.)" [The fate of "kulak exile" (19301954)], Otechestvennaya istoriya, no. 1 (1994): 118-47. (In Russian)

Zemskov, V.N. "Sud'ba 'kulatskoi ssylki' v 1940-1954 gg." [The fate of the "kulak exile" in 1940-1954]. In Naselenie Rossii v XX veke [Population of Russia in the $20^{\text {th }}$ century], edited by Yu.A. Polyakov, vol. 2, 291-311. Moscow: ROSSPEN, 2001. (In Russian)

Zhukov, A.Yu., V.G. Makurov, and I.G. Petukhova, eds. GULAG v Karelii: sbornik dokumentov i materialov (1930-1941) [GULAG in Karelia: a collection of documents and materials (1930-1941)]. Petrozavodsk: Karel'skii nauchnyi tsentr RAN, 1992. 225 p. (In Russian) 